\title{
GEOLOGY, ENERGY AND MINERAL RESOURCES ASSESSMENT OF THE BILL WILLIAMS AREA, ARIZONA
}

\author{
BY \\ A. WODZICKL JAN KRASON AND SUSANN K. ERUVER \\ GEOEXPLORERS INTERNATIONAL, INC. \\ 5701 East Evans Avenue \\ Denver, Colorado 80222 \\ Telephone 303-759-2746
}

\author{
Prepared for: \\ United States Department of the Interior \\ BUREAU CF LAND MANAGEMENT \\ Decembs: 31,1982 \\ Geo-Scientific, Professional and Engineering Sersices
}


$+\ldots \cdot \ldots$ 


\section{TABLE OF CONTENTS}

Summary. . . . . . . . . . . . . . . . . . . . . 1

Introduction ...................... . . . . . . . 3

Purpose and methodology . . . . . . . . . . . . . . 3

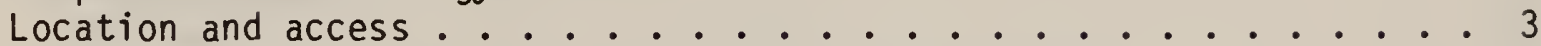

Physiography .. . . . . . . . . . . . . . . . . . 5

Geology. . . . . . . . . . . . . . . . . . . 7

Lithostratigraphy-rock units. . . . . . . . . . . . . . 21

01der Precambrian rocks. . . . . . . . . . . . . . 21

Paleozoic. . . . . . . . . . . . . . . . . 24

Mesozoic . . . . . . . . . . . . . . . . . . 25

Laramide orogenic period . . . . . . . . . . . . 27

Metamorphic core complexes . . . . . . . . . . . . 28

Mid-Tertiary . . . . . . . . . . . . . . . 30

Late Tertiary. . . . . . . . . . . . . . . . . . 33

Late Tertiary and Quaternary . . . . . . . . . . 35

Structural geology . . . . . . . . . . . . . . . . . 35

Geologic history. . . . . . . . . . . . . . . 38

Paleontologic documentation . . . . . . . . . . . . . . 41

Energy and mineral resources . . . . . . . . . . . . . . . . . . 43

Known mineral deposits, mines or prospects with recorded production . 43

Known prospects, mineralized areas and geothermal resources

with no recorded production. . . . . . . . . . . . . . 61

Mining claims, leases, and material sites . . . . . . . . 72

Mineral deposit types... . . . . . . . . . . . . . 85

Precambrian. . . . . . . . . . . . . . . . 86

Paleozoic and Mesozoic sediments ............ . . 88

Laramide intrusives. . . . . . . . . . . . . . . . . . 91

Mid-Tertiary metamorphic core complexes. . . . . . . . . . 92

Mid-Tertiary volcanic rocks. . . . . . . . . . . . . 94

Mid-Tertiary sediments . . . . . . . . . . . . . 96

Late Tertiary sediments. . . . . . . . . . . . 998

Recent Alluvium. . . . . . . . . . . . . . . 98

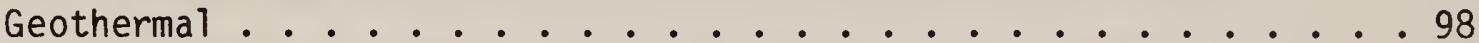

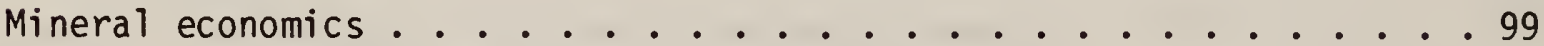

The geology, energy and mineral resources of the

Wilderness Study Areas. . . . . . . . . . . . . . . . 103

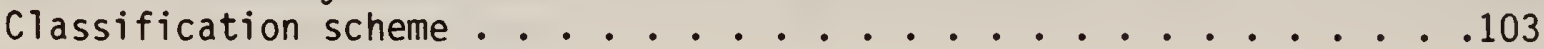

Level of confidence scheme. . . . . . . . . . . . . . . . . . . . . . . . . . . . . . . . .

The Needles eastern addition (050-005B) . . . . . . . . . 104

Physiography . . . . . . . . . . . . . . . . 104

Geology. . . . . . . . . . . . . . . . . . 104

Mineral deposits . . . . . . . . . . . . . . . . 105

Land classification for GEM resources potential. . . . . . . . . . . . . . . . . .

Recommendations. . . . . . . . . . . . . . . . . . . . . . . . . . . . . . .

The Gibraltar Mountain WSA (050-012). . . . . . . . . . . . 107

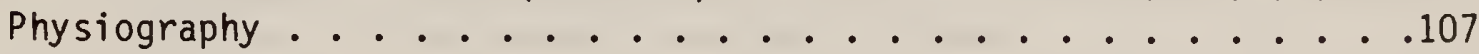

Geology. . . . . . . . . . . . . . . . . . . . . . . . . . . . . . . . . . . . . . . . .

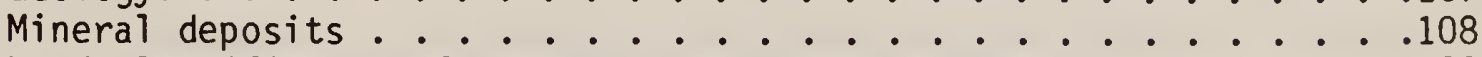

Land classification for GEM resources potential. . . . . . . . . . . . . .

Recommendations. ......................... . . . . . . . . . . . . .

The Planet Peak WSA $(050-013)$. . . . . . . . . . . . . . . . . . . . . . . . . . . . . . . . . .

Physiography .......................... . . . . . . . . . . . . . . . .

Geology. . . . . . . . . . . . . . . . . . . . . . . . . . . . . . . 
Mineral deposits . . . . . . . . . . . . . . . . . . . . . . . . . . . . . . .

Land classification for GEM resources potential. . . . . . . . . . . . . .

Recommendations......................... . . . . . . . . . .

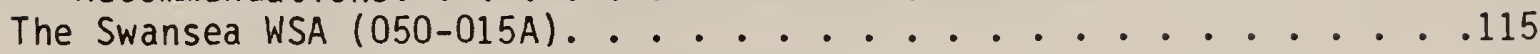

Physiography . . . . . . . . . . . . . . . . . . . . . . . . . . . . . . .

Geology. . . . . . . . . . . . . . . . . . . 116

Mineral deposits . . . . . . . . . . . . . . . . . . . . . . . . . . . . . . . .

Land classification for GEM resources potential. . . . . . . .117

Recommendations. . . . . . . . . . . . . . . . . . . . . . . . 121

The Cactus Plain (050-014 A/B) and East Cactus Plain (050-017) WSAs .121

Physiography . . . . . . . . . . . . . . . . 121

Geology. . . . . . . . . . . . . . . . . . . 122

Mineral deposits . . . . . . . . . . . . . . . . . . . . . . . . . . . .

Land classification for GEM resources potential. . . . . . . . . . . . . .

Recommendations. . . . . . . . . . . . . . . . . . . . . . .

References . . . . . . . . . . . . . . . . . . . 125

\section{LIST OF ILLUSTRATIONS}

Figure 1: Location of the Havasu and Buckskin sub-areas of the Bill Williams GRA. Surface physiography and depth to basement contours in feet, after Oppenheimer and Sumner (1981).

Figure 2: Paleotectonic and paleogeographic maps of Arizona showing location of the Bill Williams GRA.

Figure 3: Geologic, energy and mineral resources map of the Havasu sub-area, Arizona.

Figure 4: Geologic, energy and mineral resources map of the Buckskin sub-area, Arizona.

Figure 5: Legend for geologic energy and mineral resources maps.

Figure 6: Chronology of rock units and major events. After Reynolds (1980).

Figure 7: Claim density map, with oil and gas leasing status, of the Havasu sub-area, Arizona.

Figure 8: Claim density map, with oil and gas leasing status, of the Buckskin sub-area, Arizona.

Figure 9: Location of oil and gas exploration wells in southern Arizona, after Jones (1979).

Figure 10: Favorability and level of confidence map for metallic mineral resources of the Havasu sub-area, Arizona.

Figure 11: Favorability and level of confidence map for metallic mineral resources of the Buckskin sub area, Arizona.

Figure 12: Favorability and level of confidence map for uranium resources of the Buckskin sub-area, Arizona. 

Figure 13: Favorability and level of confidence map for non-metallic resources of the Buckskin sub-area, Arizona.

\section{TABLES}

Table 1: Wilderness Study Areas in the Bill Williams GRA.

Table 2: Claim density records in the Wilderness Study Areas (USA), Bill Williams GRA according to BLM (June 1982), Arizona State Office.

Table 3: Geological environments of the Bill Williams area and associated potential mineral deposit types. 


\title{
GEOLOGY, ENERGY AND MINERAL RESOURCES ASSESSMENT IN THE BILL WILLIAMS AREA, ARIZONA \\ by
}

Antoni Wodzicki, Jan Krason, and Susan K. Cruver

\section{SUMMARY}

The Bill Williams "Geological, Energy and Minerals (GEM) Resources Area" (GRA) lies within Mohave and Yuma Counties, Arizona, and San Bernardino County, California, and contains the following Wilderness Study Areas (WSAs):

\author{
Needles Eastern Addition (050-005B) \\ Gibraltar Mountains (050-012) \\ Planet Peak (050-013) \\ Swansea (050-015A) \\ Cactus P1ain (050-014A/B) \\ East Cactus Plain (050-017).
}

Basement rocks consist of Precambrian (1.8-1.6 b.y.B.P.) metavolcanic and metasedimentary gneisses intruded locally by granites 1.7 to 1.6 and 1.5 to 1.4 b.y.B.P. The basement is unconformably overlain by Cambrian shallow-marine sandstones and sandy mudstones which in turn are disconformably overlain by a thick sequence of Devonian to Permian shallow marine carbonates and sandstones. During the mid-Mesozoic a magmatic arc extended over the southwestern part of the GRA and a thick sequence of continental red beds were deposited. They are preserved only locally in the southern part of the GRA. S-type granites were intruded during the Laramide (70-50 m.y.B.P.) and they may be associated with early stages of metamorphic core complex emplacement. The mid-Tertiary orogeny lasted from 35 to 14 m.y.B.P. and involved the following: Deposition of a thick sequence of fluvial and lacustrine sediments in northwest-striking downwarps; outpouring of voluminous calc-alkaline volcanics dominated by ash flow deposits possibly related to cauldrons; emplacement of metamorphic core complexes; and listric normal faulting which offset mid-Tertiary volcanic and sedimentary rocks. Basin and Range faulting became dominant 14-4 m.y.B.P. and was accompanied by bimodal volcanism. Since $4 \mathrm{~m} . y . B . P$. the main geological processes have been erosion and depostion of aluvium.

Geologic environments potentially favorable for the occurrence of mineral or energy resources in the GRA include: Precambrian metavolcanic gneiss; Precambrian granite contacts; Laramide intrusives; mid-Tertiary metamorphic core complexes; mid-Tertiary basin fill sediments; and Recent alluvium.

Massive sulfide deposits are associated with Precambrian metavolcanic gneisses to the north, but no such occurrences are known within the GRA. Six small gold-tungsten bearing veins cut gneisses and may be related to nearby Precambrian granite. The Laramide intrusives within the GRA are S-type granites which lie outside the main NW and ENE - striking porphyry copper belts, and are not likely to be favorable host rocks for porphyry copper-type 

mineralization. Most of the copper, gold and silver deposits in the Cienga, Santa Maria and Midway Mining districts occur along or close to dislocation surfaces and listric normal faults related to metamorphic core complex emplacement. Nearly 1.5 million tons of ore were produced from these districts and the complexes are considered to be moderately to highiy favorable for the occurrence of metallic ore deposits. Gold, silver, base metals, barite, fluorite and manganese mineralization occurs in the Plomosa Mining District which extends into the southern part of the GRA. These deposits occur along shears and are probably related to mid-Tertiary igneous activity. Mid- to late Tertiary valley-fill sediments contain abundant uranium source rocks and permeable horizons, and locally may contain reductants. They are considered of low to moderate favorability for the occurrence of uranium deposits. Minor placer gold deposits occur in Recent alluvium near some gold-bearing mining disticts.

The Needles Eastern Addition WSA is underlain by Precambrian gneiss and mid-Tertiary andesitic volcanics. No mineral occurrences are present within the WSA, and it has a low favorability for the occurrence of metali ic mineral deposits.

The Gibraltar Mountain, Planet Peak and Swansea WSAs are underlain by both lower and upper plate rocks of metamorphic core complexes, and postcomplex basalt, silicic volcanics and valley-fill sediments. Rocks near the dislocation surface between upper and lower plates contain numerous copper, gold, and silver deposits of the Cienega and Santa Maria Mining districts and are considered highly favorable for the occurrence of metallic minerals. The northern part of the Swansea and Planet Peak WSAs are moderately favorable for the occurrence of uranium because of nearby uranium source rocks and possible precipitants. Other parts of the WSAs have low or no favorability for metallic minerals, non-metallic minerals, and uranium.

The Cactus Plain and East Cactus PIain WSAs are underlain by mid-Tertiary sediments and volcanics, and in the east by a metamorphic core complex. The northeastern part of East Cactus Plain WSA is moderately favorable for occurrence of metallic deposits because it probably lies near a dislocation surface and two mines within the Midway Mining District lie close to the area. The southern part of the Cactus Plain WSA is moderately favorable for non-metalic minerals because it contains two barite occurrences which 1 ie at the northern limits of the Plomosa Mining District. Other parts of the WSAs have low favorability for uranium.

Important recommendations for further work in the WSAs include:

1. Mineralization associated with metamorphic core complexes should be studied to determine whether it is supergene or hypogene.

2. Rocks near dislocation surfaces should be geochemically studied to determine whether there has been significant enrichment in metallic elements.

3. Uranium solubility index should be calculated for well waters in areas potentially favorable for uranium. 



\section{INTRODUCTION}

\section{Purpose and Methodology}

The need for "Geological, Energy and Minerals (GEM) Resources Assessment" of "Wilderness Study Areas" (WSA) has been recognized for some time by the Bureau of Land Management (BLM). The assessment is now being performed by various contractors for the BLM.

Wilderness Study Areas, widely scattered within the Sonoran Desert. and Mexican Highlands and grouped into Region 5 by the BLM, are being studied and assessed by Geoexplorers International, Inc.. The present, report pertains to six WSAs in southwestern Arizona which have been grouped together into the Bill Williams Geological, Energy and Mineral Resources Area (GRA).

The purpose of the present study is to assess the potential for locatable, leasable and salable resources within the GRA, and specifically within each of the WSAs. This assessment has been carried out through literature study of the geology, structure and economic geology of the GRA, and a consideration of the regional paleogeographic, plate tectonic and metallogenis setting of the GRA within the solthern Cordillera. Thus, the assessment is not only based on data from the GRA itself, but also on metallogenic concepts within the regional paleogeographic and plate tectonic framework.

\section{Location and Access}

The Bill Williams GRA is located in Mohave and Yuma counties, southwestern Arizona and in San Bernadino County, southeastern California. It lies within the Havasu and Yuma Resource Areas of the BLM-adminstered Yuma District and the Kingman and Lower Gila Areas of the BLM-administered Phnenix 

District. the GRA is located near the corner junction of the Prescot.t, Phoenix, Salton Sea and Needles 1:250,000 quadrangles, approximately between latitudes 33 degrees 50 minutes and 34 degrees 45 minutes and longitudes 113 degrees 45 minutes and 114 degrees 25 minutes. The Bill Williams GRA has been subdivided into the Havasu and the Buckskin sub-areas as shown in figure 1. The six WSAs within the GRA are listed in table 1 and their locations are shown in figure 1 .

Table 1: Wilderness Study Areas in the Bill Williams GRA

\begin{tabular}{|c|c|c|c|c|}
\hline Sub-Area & WSA No. & WSA Name & Area-acres & $\mathrm{km} \mathrm{sq}$. \\
\hline Havasu & $050-005 B$ & $\begin{array}{l}\text { Needles Eastern } \\
\text { Addition }\end{array}$ & 465 & 1.9 \\
\hline \multirow[t]{5}{*}{ Buckskin } & $050-012$ & $\begin{array}{l}\text { Gibraltar } \\
\text { Mountains }\end{array}$ & 25,260 & 102.2 \\
\hline & $050-013$ & Planet Peak & 17,645 & 71.4 \\
\hline & $050-015 A$ & Swansea & 41,850 & 169.4 \\
\hline & $050-014 A / B$ & Cactus Plain & 70,360 & 284.7 \\
\hline & $050-017$ & East Cactus Plain & 13,735 & 55.6 \\
\hline & & Total & 169,315 & 685.2 \\
\hline
\end{tabular}

Important access into the Bill Williams GRA is provided by the Atchison, Topeka and Santa $\mathrm{Fe}$ railroad and Arizona highway 72 , which run across the southern part of the GRA. Access to most of the valleys in the GRA is along light duty and unimproved dirt roads but access for vehicular traffic to the mountainous areas is Timited. No major towns are present in the GRA, but Parker lies just west of the Buckskin sub-area, and Phoenix lies ahout $10 n$ miles to the east and Yuma some 85 miles to the south of the GRA. 


\section{PHYSIOGRAPHY}

The Bill Williams GRA lies within the Sonoran Desert section of the southern Basin and Pange province (Fenneman, 1931; Heindl, 1060), which here lies to the southwest of the Colorado Plateau. The area has a northeast and locally northwest-trending tonographic grain, which probabiy reflect warping associated with metamorphic core complexes, and basin and range normal faulting, respectively. The fault scarps have been eroded back considerah?e distances to form pediments, and range fronts are considerably embayed. This is because much of southwestern Arizona has been almost free of tectonic activity for the past several million years (Tucker, 1980; Davis, 1981).

The GRA can be divided into three distinct physiographic, terrains (fig. 1): mountainous to hilly terrain, lowland terrain, and the Colorado River gorge.

The mountainous to hilly terrain constitute tectonic uplifts which are cored largely by metamorphic rocks. The Buckskin and Rawhide Mountains trend northeast, probably reflecting warping associated with emplacement of metamorphic core complexes; the Plomosa, Mohave, Bill Williams and Hualapai Mountains trend north-south to northwest and probably are a result of basin and range faulting.

The lowland terrains constitute tectonic depressions in which valley-fill sediments have been deposited and which have been widened through the formations of pediments. The Butler Valley and several smaller valleys in the Buckskin Mountains represent tectonic downwarps associated with emplacement of metamorphic core complexes (Davis, 1981), whereas the north to northwest-trending Plomosa and Ranegras Plains and the Sacramento Valley probably reflect basin and range faulting.

A gorge is cut into the Whipple and Buckskin llountains by the Colorado 



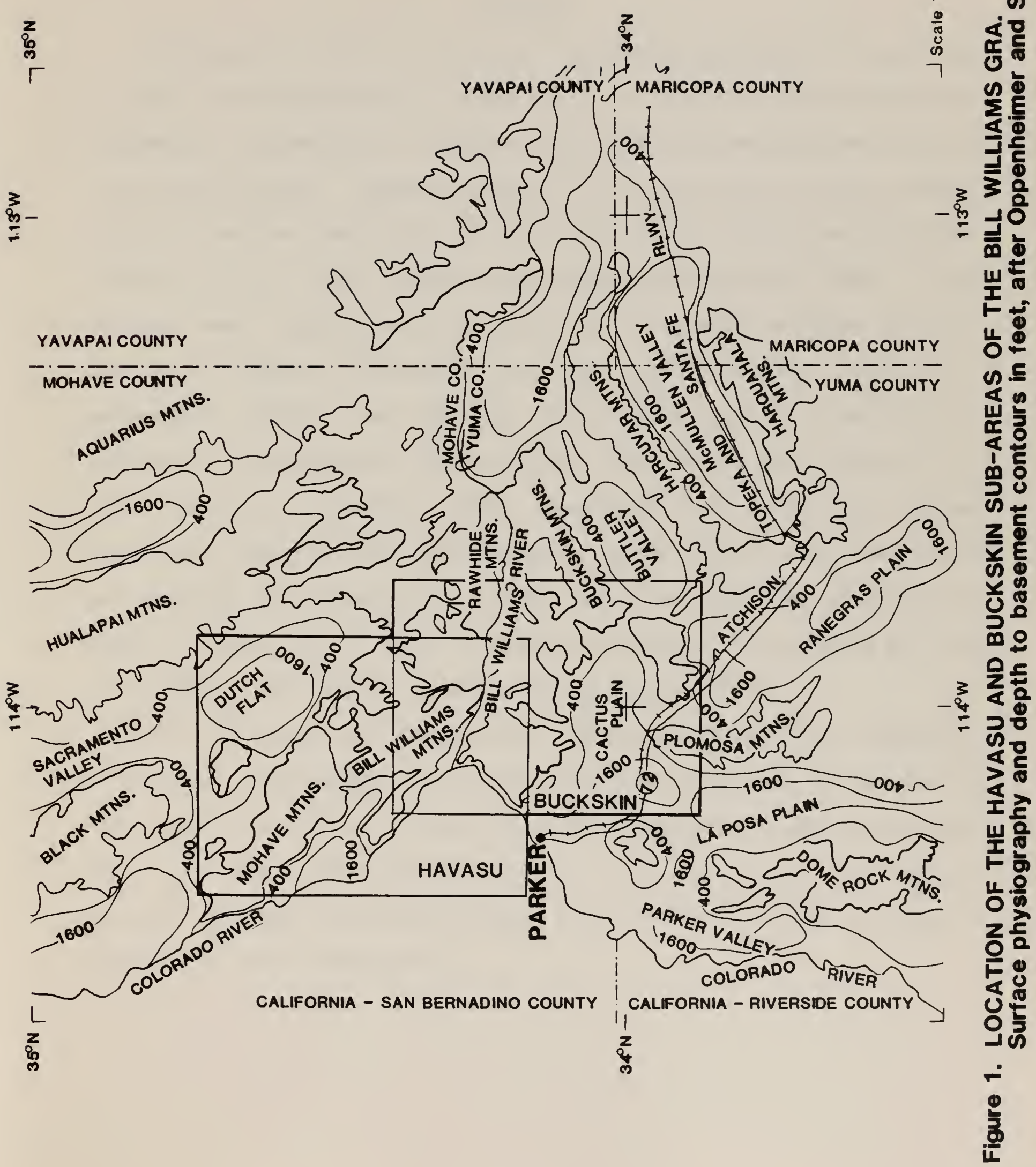



River. This appears to be a young feature possibly related to basin and range uplift accompanied by downcutting of the Colorado River.

\section{GEOLOGY}

Southwestern Arizona is an area of highly complex geology. Rocks range in age from Precambrian to Recent and the region has been affected by Precambrian, mid-Mesozoic, Laramide and mid-Tertiary orogenies and by basin and range faulting. Important advances in the understanding of this complex terrain have been made since the publication of the Geologic Map of Arizona (Wilson et al., 1969), and have been summarized by Reynolds (1980). These advances have largely been the result, of a greatly increased number of radiometric dates (Shafiqullah et a1., 1980); regional ana?ysis of deformation (Rehrig and Heidrick, 1976; Davis, 1981); recognition of metamorphic core complexes (Davis and Coney, 1979; Coney, 1980; Davis et, a1., 1980; Rehrig and Reynolds, 1980); recognition of the relationship between subduction, magmatism and metallogenesis in the southern Cordillera (Coney and Reynolds, 1977; Damon et al., 1981); and an increased level of mapping of Cenozoic basins as a result of intense uranium exploration during the late 1970 's (Eberly and Stanley, 1978; Scarborough and Wilt, 1979).

The lithology and stratigraphy, structural geology and tectonics, paleontology and geologic history of the Bill Williams GRA are described in this section in order to facilitate the assessment of mineral potential within the GRA, and specifically within the enclosed WSAs. The regional geologic setting and detailed geology of the Bill Williams GRA are shown in figures 2,3 and 4 , respectively. 

Figure 2: Paleotectonic and paleogeographic maps of Arizona showing location of the Bill Williams GRA.

A. Location of Precambrian terrains and the Holbrook, Bright Angle-Mesa Butte and Colorado lineaments, after Warner (1978) and Titley (1982).

B. Location of mid-Mesozoic magmatic arc, the Mojave-Sonora megashear and mid- to late Mesozoic red beds, after Dickinson (1981). The red beds postdate the magmatic arc and probably extend farther to the southwest than shown.

C. Location and age trends of major porphyry copper deposits. Note that these are aligned parallel to northwest-trending Paleozoic-Mesozoic discontinuities (Lowel1, 1974; numbers 1-6 correspond to discontinuities named in Heidrick and Titley, 1982), along northwest-trending Laramide magmatic arcs ( $v$ pattern), and along northeasterly Precambrian trends (Heidrick and Titley, 1982). Curved black lines show location of arc at different times, as given.

D. Location of Precambrian alkali and alkali-calcic intrusions and mid-Tertiary metamorphic core complexes, mid-Tertiary alkali-calcic volcanics and sedimentary domains (Scarborough and Wilt, 1979). 


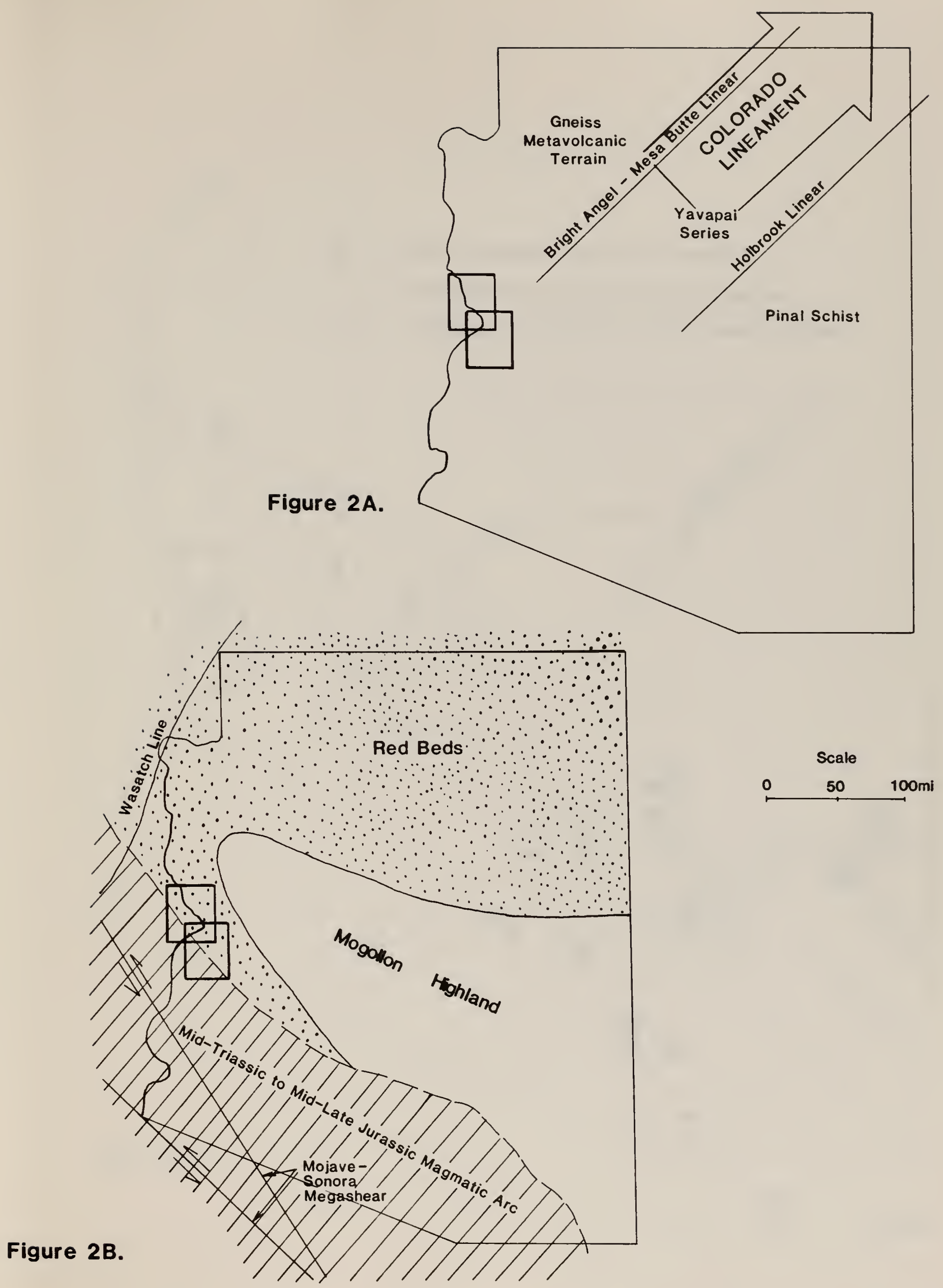





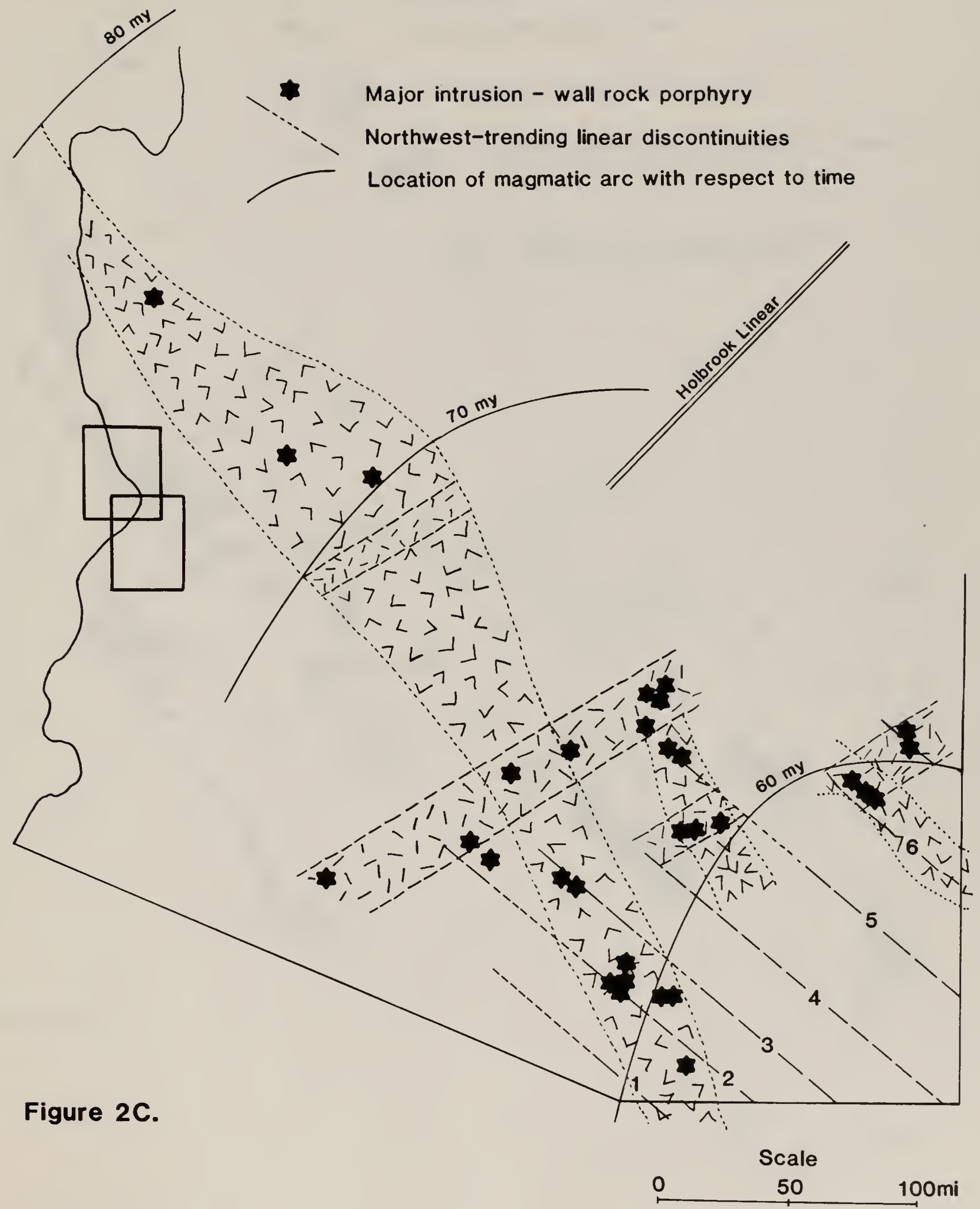





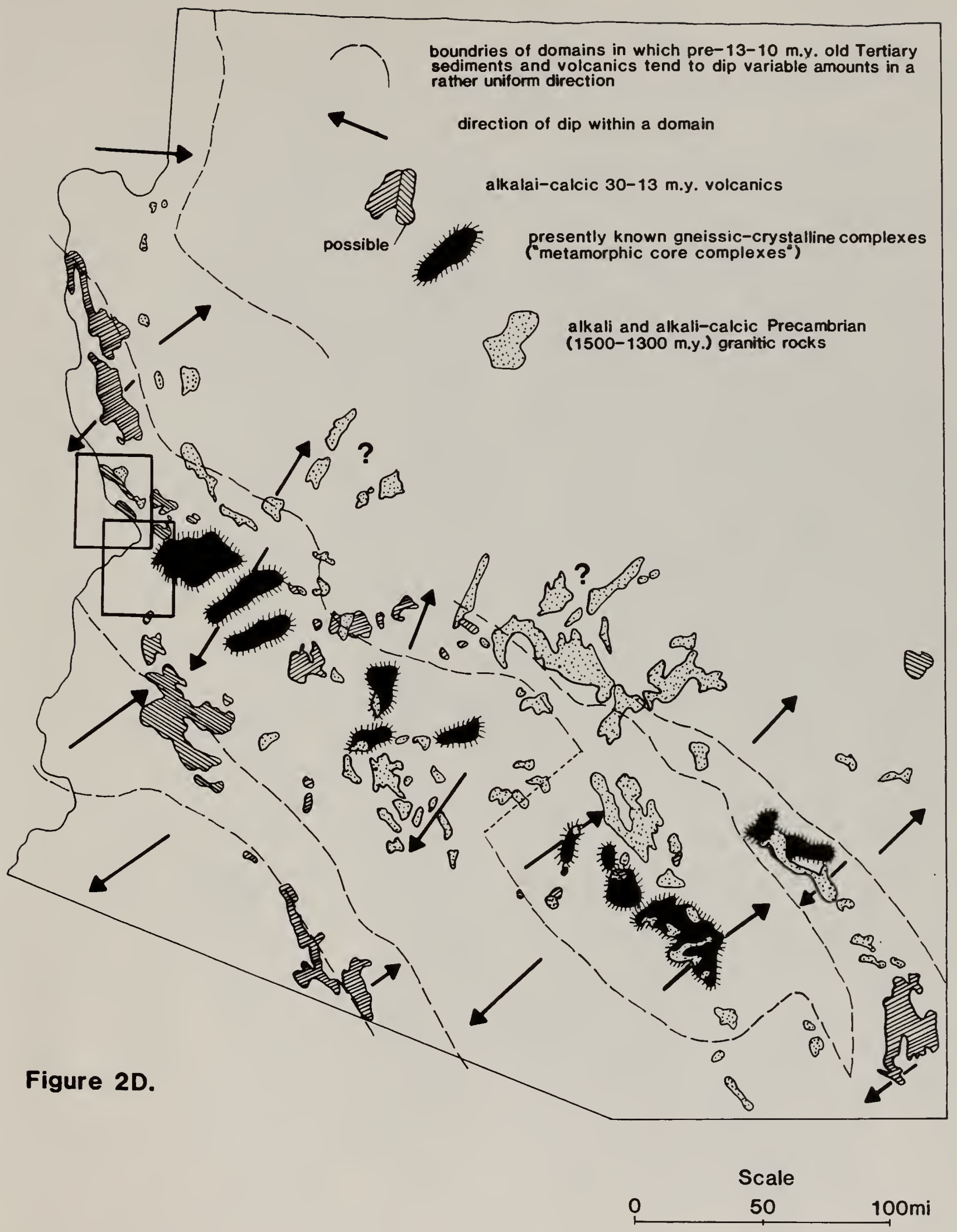





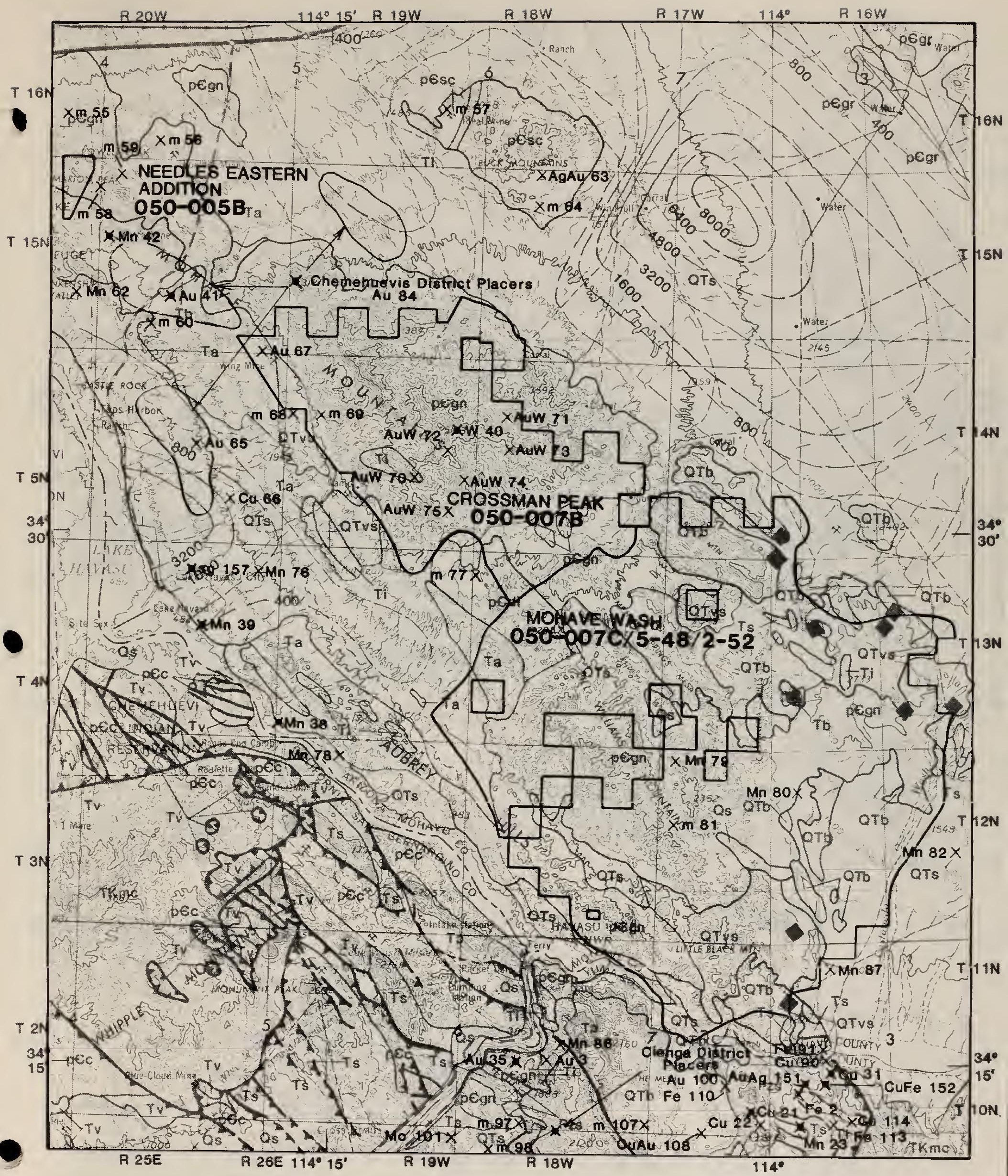

FIG. 3 GEOLOGIC. ENERGY AND MINERAL RESOURCES MAP OF THE HAVASU SUB-AREA, ARIZONA 



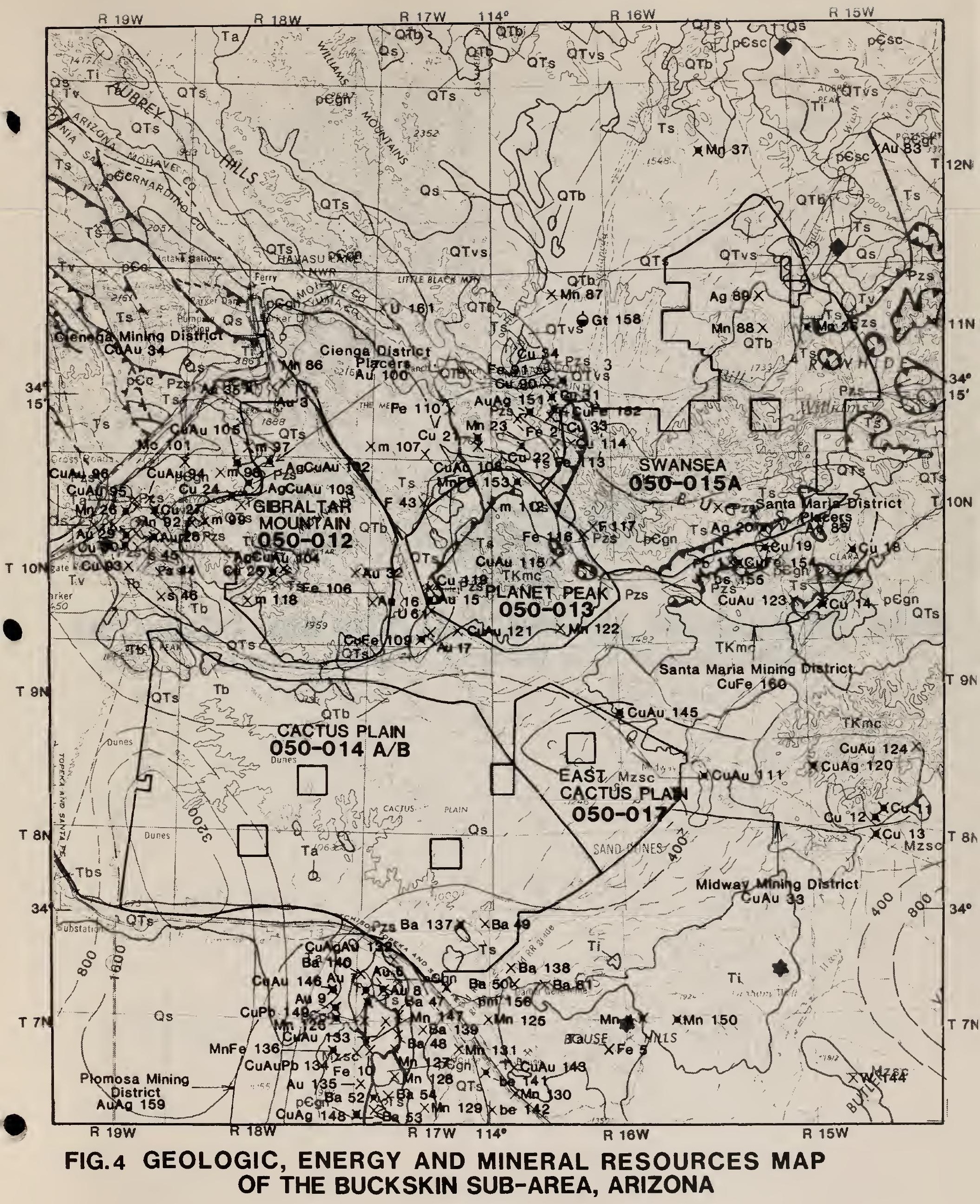

Scale

$1: 250,000$

LEGEND: see enclosed 

Figure 5.

GEOLOGIC, ENERGY AND MINERAL RESOURCES MAPS

Scale of all maps is 1:250,000 or as otherwise indicated. 



\section{LITHOSTRATIGRAPHY}

After Reynolds (1980), Davis, et al. (1980), and Wilson, et al. (1969) with modifications from Oppenheimer and Sumner (1981), Scarborough and Wilt (1979), Sunes on and Lucchitta (1979), Eberly and Stanley (1978).

\section{QUATERNARY}

LATE TERTIARY
TO QUATERNARY

QTvs

Tbs

Ts

Tb

MID-TERTIARY

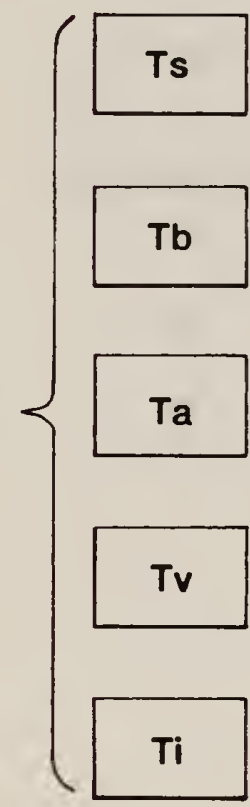

\section{CRETACEOUS}

TO TERTIARY

TKmc

MESOZOIC

Mzsc
Unconsolidated alkuvial fan and floodplain deposits.

Poorly consolidated fanglomerates and fluvial sands and gravels.

Basaltic flows and flow breccias.

Rhyolitic flows and tuffe.

Bouse Formation, marine limestone and siltstone.

Conglomerates, sandstones, mudstones and minor limestones.

Basaltic flows and breccias.

Andesitic flows, breccias and tuffs.

Undifferentiated volcarics.

Small stocks, phugs dikes, sills of myolitic to basaltic composition.

Gneiss, mylonitic gneiss and chloritic breccia of metamorphic core complexes.

Undifferentiated metavolcanic and metasedimentary schist.

Quartzite, sandstone, shale, dolomite and limestone, locally metamorphosed. 



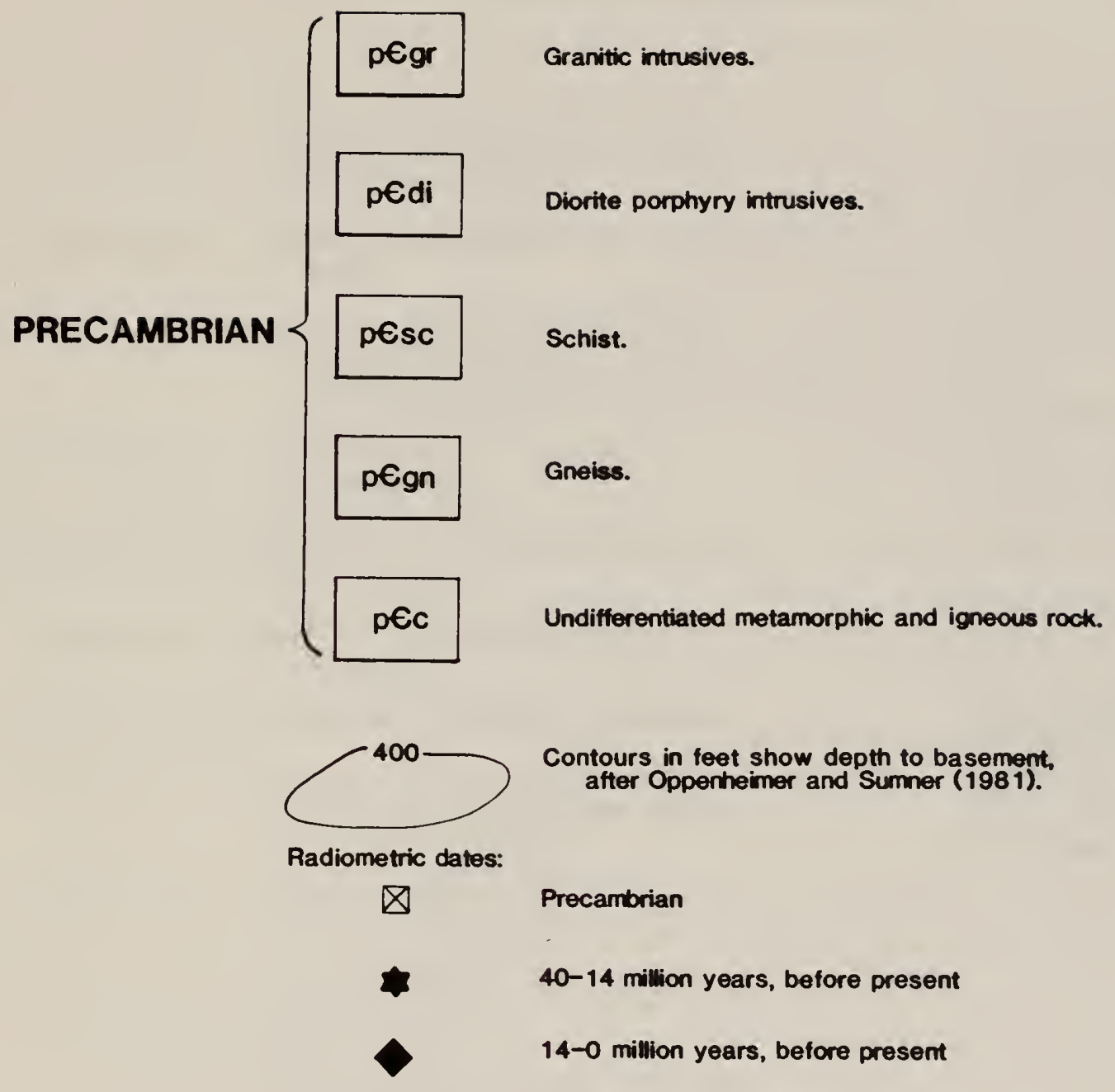





\section{SPECIAL SYMBOLS \\ OF STRUCTURAL FEATURES \\ After U.S. Geological Survey}

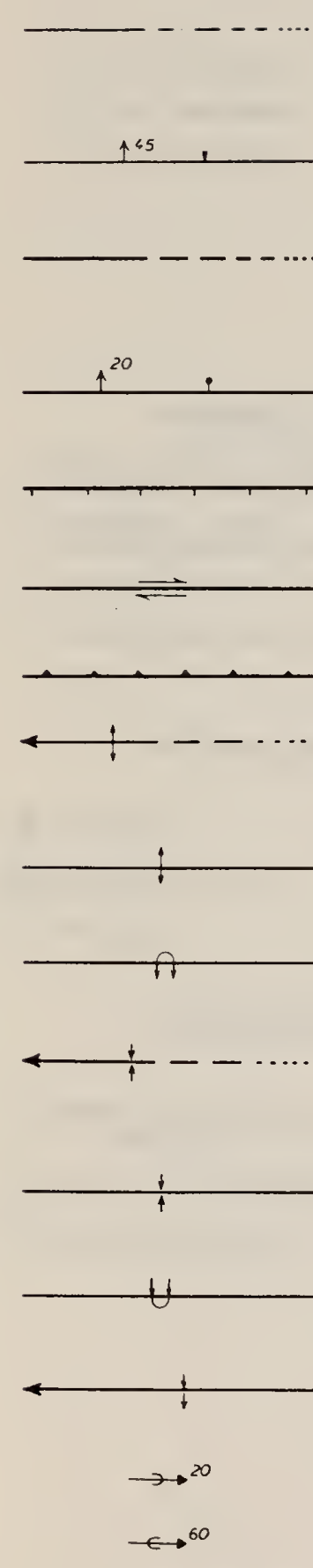

Contact - Dashed where approximately located; short dashed where inferred; dotted where concealed

Contact - Showing dip; well exposed at triangle

Fault - Dashed where approximately located; short dashed where inferred; dotted where concealed

Fault, showing dip - Ball and bar on downthrown side

Normal fault - Hachured on downthrown side

Fault - Showing relative horizontal movement

Thrust fault - Sawteeth on upper plate

Anticline - Showing direction of plunge; dashed where approximately located: dotted where concealed

Asymmetric anticline - Short arrow indicates steeper limb

Overturned anticline - Showing direction of dip of limbs

Syncline - Showing direction of plunge; dashed where approximately located; dotted where concealed

Asymmetric syncline -- Short arrow indicates steeper limb

Overturned syncline - Showing direction of dip of limbs

Monocline - Showing direction of plunge of axis

Minor anticline - Showing plunge of axis

Minor syncline - Showing plunge of axis
Strike and dip of beds - Ball indicates top of beds known from sedimentary structures

$\overbrace{}^{70}$ Inclined $\oplus$ Horizonial

+ Vertical 80 Overturned

Strike and dip of foliation

20 Inclined - Vertical + Horizontd

Strike and dip of cleavage

$\stackrel{15}{ }$ Inclined $\longmapsto$ Vertical $f$ Horizontal

Bearing and plunge of lineation

15 - Inclined - Verlical $\longleftrightarrow$ Ilorizontal

Strike and dip of joints

- 40 Inclined - Vertical - Horizonial

Note: planar symbols (strike and dip of beds, foliation or schistosity. and cleavage) inay be combined with linear symbols to record data observed at same locality by superimposed symbols at point of observation. Coevisting planar symbols are shown intersecting at point of observation. 


\section{SPECIAL SYMBOLS \\ FOR ENERGY AND MINERAL RESOURCES}

\section{KNOWN DEPOSITS AND OCCURRENCES}
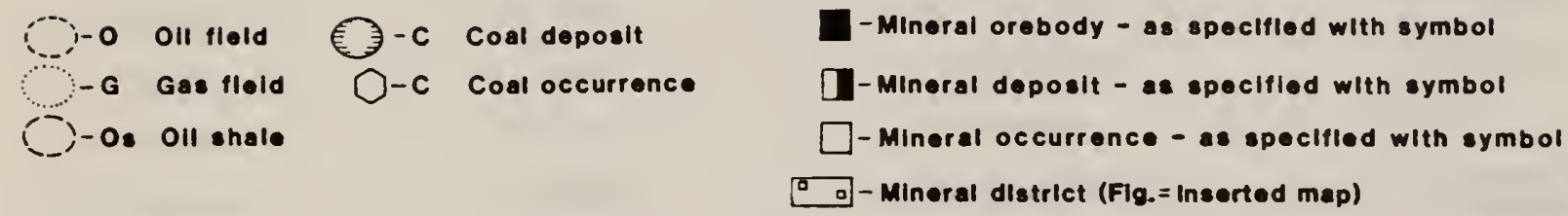

\section{EXPLORATION AND/OR MINING ACTIVITY}

\section{MINERALS AND COAL}

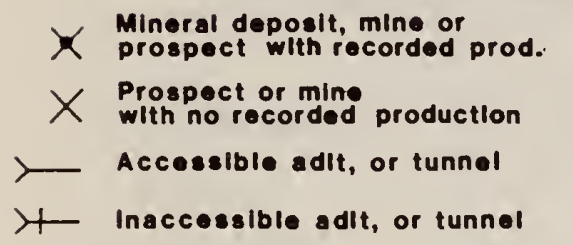

$\square$ vertical shaft

4 Inclined shaft

A Active open plt, or quarry

$\forall$ inactlve open pit, or quarry
Active gravel or clay (cl) plt

X Inactive gravel or clay (cI) plt

Exploration hole with data avallable

$Q$ Exploration hole without data

$x \quad x$ Mining distrlct (Flg.= Inserted map)

\footnotetext{
PETROLEUM

OII well

OII and gas well

X. Gas woll

GROUND WATER

water well of speclal Importance

屯 water well of high yleld

Flowing water well

Y show of gas

show of oll
show of oll and gas
shut-in well

- Dry well - abandoned

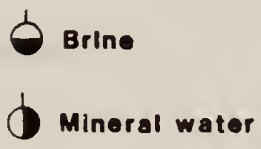

Mineral water

Thermal water

$\$$ Radloactive water

A Thermal point
}

- $\mathrm{CO}_{2}$ - or He-hellum- rich well

\section{ENERGY RESOURCES}
O OII
G Gas
Os Oll shale
Ot Tar sands

C Coal

U Uranium

Cb Lignite (brown coal)

Th Thorlum

Cp peat

Gt Geothermal 



\section{MINERAL RESOURCES}

METALS

$\begin{array}{lll}\text { Al Aluminum } & \text { Cu Copper } & \text { Mo Molybdenum } \\ \text { Sb Antimony } & \text { Ga Gallium } & \text { Ni Nickol } \\ \text { As Arsenic } & \text { Go Germanium } & \text { No Niobium or Columblum } \\ \text { B. Beryilium } & \text { Au Goid } & \text { Pt Piatinum group } \\ \text { Bi Bismuth } & \text { Fo Iron } & \text { RE Rare earth } \\ \text { Cd Cadmium } & \text { Pb Lead } & \text { Re Rhenium } \\ \text { Cr Chromium } & \text { LI Lithium } & \text { Sc Scandium } \\ \text { Cs Cosium } & \text { Mn Manganese } & \text { Ag Silver } \\ \text { Co Cobait } & \text { Hg Mercury } & \text { To Tollurium }\end{array}$

NONMETALS - INDUSTRIAL MINERALS

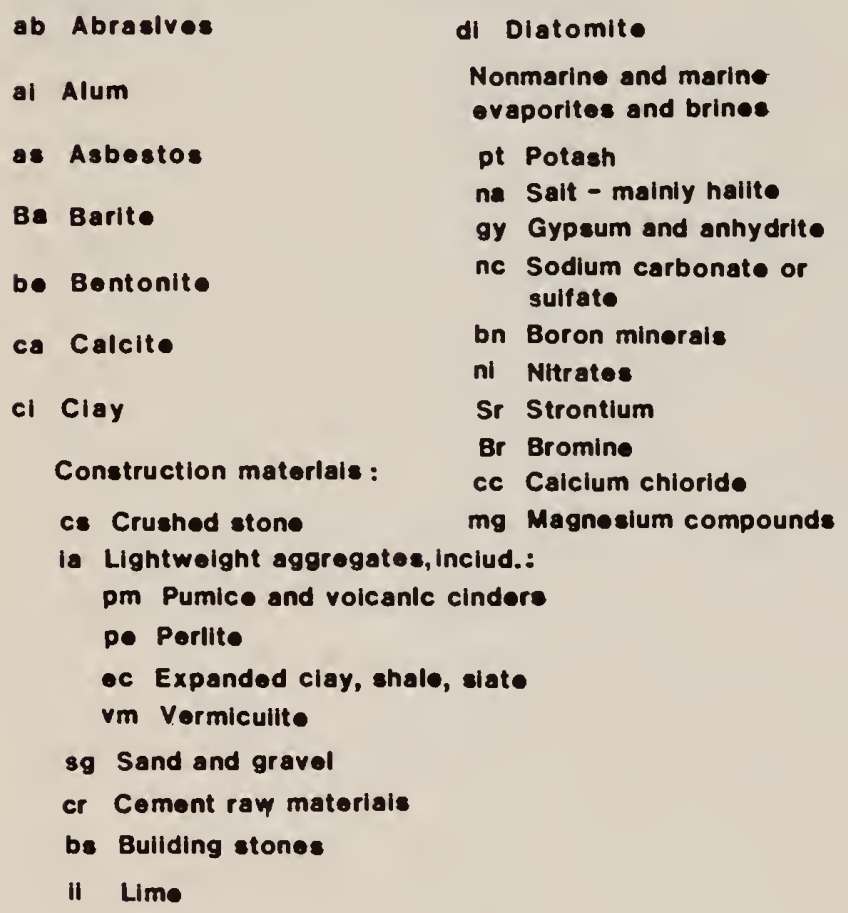

$\begin{array}{ll}\text { fs Foldspar } & \text { mg Magnesian } \\ \text { F Fiuorite(fiuorspar) } & \text { mi Mica } \\ \text { gs. Gem stones } & \text { ph Phosphate } \\ \text { ge Graphite } & \text { pi Plgment and fillers } \\ \text { He Hellum } & \text { qz Quartz crystals } \\ \text { kI Kaolln } & \text { si Sllica sand } \\ \text { ky Kyanite and related } & \text { S Suifur } \\ \text { Is Limestone } & \text { tc Talc } \\ \text { Im Lithium minerals } & \text { ze Zoolites } \\ & \text { hm Humate }\end{array}$

TI Thallum

Sn Tin

Ti Titanium

w Tungston

v Vanadium

Zn ZIne

Zr Zirconium and Hf Hafnium 



\title{
SPECIAL GEOLOGICAL FEATURES
}

POINT OF SPECIAL GEOLOGIC INTEREST
m Mineral occurrence
I Fossil locality
$\checkmark$ Volcanic phenomenon
t Stratlgraphic sequence

\author{
- Structurai, bedding, foliation, etc., \\ b Brecciation, shear zone, etc., \\ y High yield spring \\ p Spring with mineral water
}

u Radloactive epring

g Thermal spring

a Extensive rock alteration

r Lithoiogic type looaity

FAVORABILITY POTENTIAL AND LEVEL OF CONFIDENCE FOR MINERAL RESOURCES

\section{FAVORABILITY:}

$1 A$ - Undefined

1 - Not fevorabie - combine with elther B, C, or D

2 - Low

3 - Moderate

4. High

\section{LEVEL OF CONFIDENCE:}

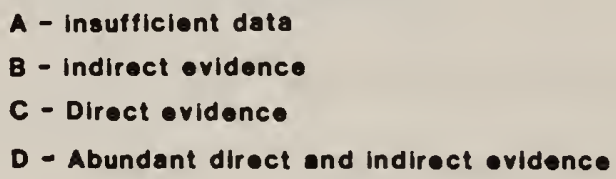

D - Abundant direct and indirect evidence 



\section{Lithostratigraphy - Rock Units}

In southwestern Arizona older Precambrian crystalline basement is overlain by younger Precambrian and Paleozoic shallow marine sediments; Mesozoic volcanics and continental clastic sediments, mid-Tertiary volcanics and clastic continental sediments; and late-Tertiary volcanics and valley-fill sediments. Intrusive activity and metamorphism took place during the Precambrian, mid-Mesozoic, Laramide and mid-Tertiary. Metamorphic core complexes were probably emplaced during the latter event.

\section{1der Precambrian Rocks}

01der Precambrian rocks in Arizona crop out most extensively in the northwest-trending Central Mountain region, to the northeast of the Bill Williams GRA. Here they have been divided into three distinct northeast-trending belts (fig. 2C; Titley, 1982), which according to Anderson (1976) accreted onto the North American craton from the southeast. The northwesterly of these belts consists of gneisses which are in part metavolcanic, have been metamorphosed to the amphibolite facies (Stensrud and More, 1980) and were deposited about 1.8 b.y.B.P. (Titley, 1982). The central belt consists of the Yavapai Series which was deposited $1.82-1.775$ b.y.B.P. (Anderson and Silver, 1976). It is a greenstone belt which is 40,000 feet thick and is dominated by volcanic and volcanoclastic rocks of basaltic to rhyolitic composition (Anderson and Silver, 1976; Titley, 1982) and has been metamorphosed to the greenschist facies. Massive sulfide $\mathrm{Cu} / \mathrm{Zn}$ deposits are associated with submarine rhyolitic volcanism especially in the Prescott-Jerome area (Donnelly and Hahn, 1981). The southeastern belt consists of the Pinal schists which were deposited 1.7-1.68 m.y.B.P. (Silver, 1978 ) and consist of quartz-muscovite schist, arkose and quartzite (Titley, 1982). 



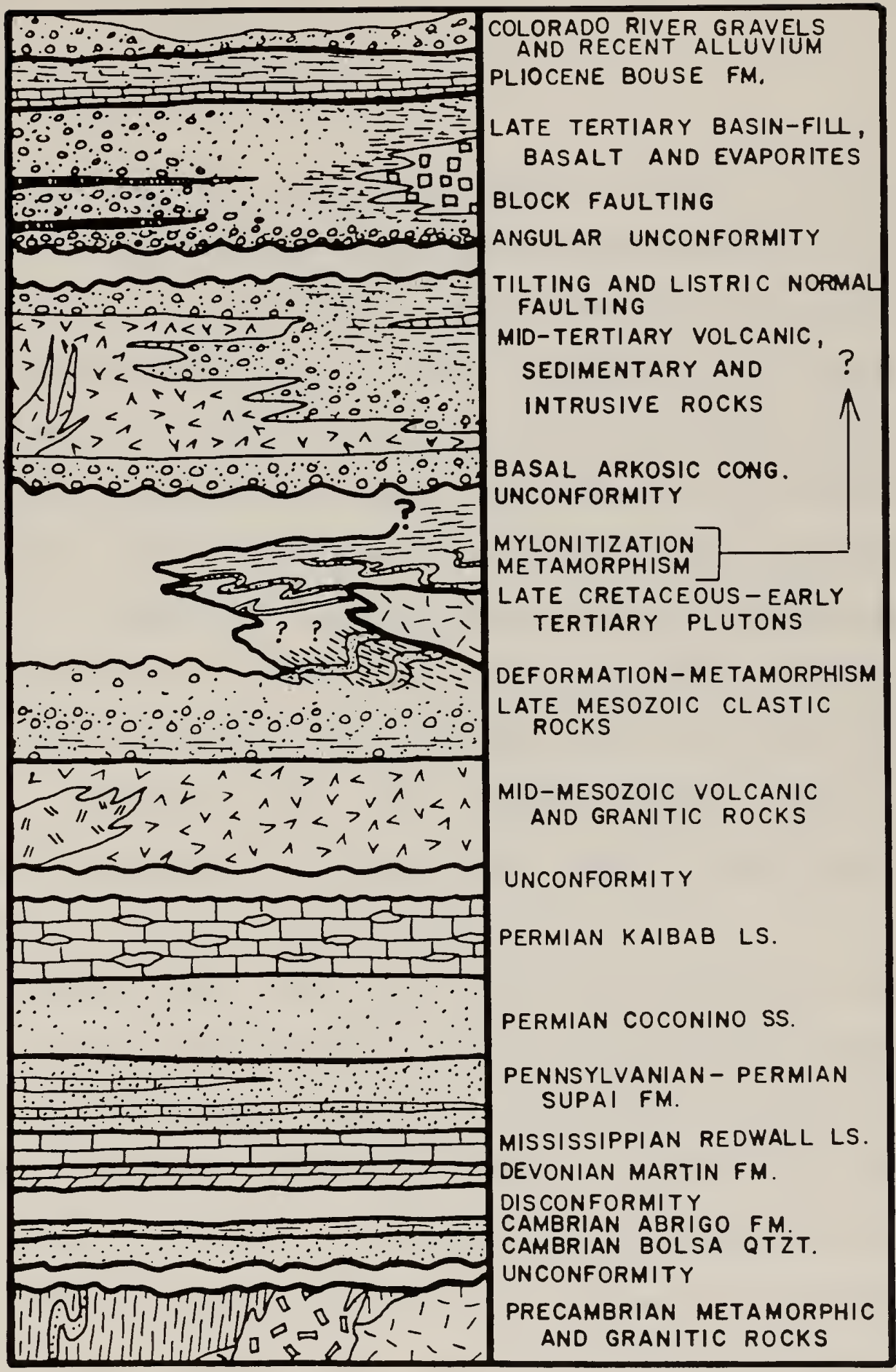

FIG. 6 CHRONOLOGY OF ROCK UNITS AND MAJOR EVENTS. After Reynolds (1980). 

The older Precambrian rocks were metamorphosed and intruded by granites during the Arizonan revolution 1.76 - 1.63 b.y.B.P. (Damon, 1968) and were intruded by granites during the llazatzal revolution 1.5-1.4 b.y.B.P. (Damon, 1968; Silver et al., 1977).

In the Bill Williams GRA, Precambrian metamorphic rocks are widespread in the Mohave, Bill Williams, Whipple, Buckskin and Rawhide Mountains, and in the latter three areas they are present in both lower and upper plates of metamorphic core complexes (Davis et a1., 1980). The southwestern extension of the boundary between the gneissic metavolcanic terrains and the schistose Yavapai Series passes approximately through the center of the Buckskin sub-area (see fig. 2a). Most of the Precambrian metamorphic rocks in the GRA consist of gneisses, except the northeast corner of the Buckskins where schists, possibly equivalent to the Yavapai Series, are present. No details are known about these metamorphic rocks in the GRA, but to the north of the Havasu sub-area, Stensrud and More (1980) describe them as quartzofeldspathic-biotite-muscovite gneiss and schist which may be metarhyolitic tuffs.

Precambrian granitic rocks crop out in the Hualapai Mountains in the northeast corner of the Havasu sub-area, in the northwestern Bill Williams Mountains in the central Havasu sub-area, and in the Ruckskin Mountains in northeastern Buckskin sub-area. Again, no details are known about these rocks in the GRA, but to the north of the Havasu sub-area Stensrud and More (1980) describe them as strongly foliated two-mica granite; weakly foliated, medium-grained biotite granodiorite; fine-grained biotite-hornblende granodiorite; and a coarsely porphyritic biotite-quartz monzonite. According to Wilson et al. (1969), Precambrian granitic rocks in southwestern Arizona may range in composition between granite and quartz diorite. $P$. Anderson (pers. comm. in Scarborough and wilt, 1979) states that they are alkalic and 
alkalic-calcic and range in age from 1.5 to 1.3 b.y.B.P.

\section{Paleozoic}

Paleozoic sedimentary rocks crop out in the Buckskin and Rawhide Mountains in northern Buckskin and southern Havasu sub-areas. Paleozoic rocks in southwest Arizona have been described by Miller (1970) and recently by Reynolds (1980). They consist mainly of quartzite, dolomite and limestone and include the Bolsa Quartzite, Abrigo Formation, Martin Formation, Escabrosa Limestone, Supai Formation, Coconino Sandstone and the Kaibab Limestone or their stratigraphic equivalents. The sediments were laid down in a shelf environment on a stable platform to the east of the Cordilleran geosyncline (see fig. 2b) from which they are separated by the Wasatch Line (Burchfiel, 1979).

The Bolsa Quartzite is Cambrian and consists of a brown to maroon quartzite. It is 330 feet thick and unconformably overlies Precambrian crystalline basement. It is conformably overlain by the Cambrian Abrigo Formation which is a sandy shale interbedded with calcareous fine-grained quartzite and is 160 feet thick.

The overlying Martin Formation is Devonian and disconformably overlies the Cambrian strata. Apparently the region was a structural high during the Ordovician and Silurian and no sediments of that age were deposited in southwest Arizona. The Martin Formation consists of dolomitic Limestone, dolomite and sandy dolomite and is 330 feet thick. The remaining Paleozoic formations form a conformable sequence. The Mississippian Escabrosa Limestone is a tan-weathering dolomite and cherty limestone, and is about 400 feet thick. The Supai Formation is Pennsylvanian to Permian, consists of white, pink, maroon or light brown quartzite interbedded with limestone and a reddish mudstone. It is between 530 and 1200 feet thick. The overlying 

Coconino Sandstone and Kaibab Limestone are Permian. The Coconino Sandstone consists of gray vitreous quartzite and is between 660 and 1100 feet thick. Finally, the Kaibab Limestone is 660 to 1100 feet thick and it consists of chert-bearing limestone.

The Paleozoic sedimentary rocks vary from virtually unmetamorphosed sediments to highly metamorphosed schistose rocks and wollastanite-bearing carbonate rocks.

\section{Mesozoic}

Mesozoic rocks in southwestern Arizona have only recently been studied in detail, and their stratigraphy and structure are imperfectly known. They can be broadly divided into mid-Mesozoic volcanic and intrusive rocks and late Mesozoic clastic sediments (Reynolds, 1980).

The mid-Mesozoic volcanic and plutonic rocks crop out to the south of the GRA, in the Plomosa Mountains where they have been described by Miller (1970) and Reynolds (1980). The volcanic rocks are dacitic, quartz latitic and rhyolitic in composition and include flows, ash-flow tuffs and agglomerates which are locally interbedded with volcanic conglomerate, sandstone and red mudstone. They are up to three miles thick. The plutonic rocks are granitic, they intrude Paleozoic sediments and are characterized by abundant $K$-feldspar phenocrysts. They have been dated as mid-Jurassic and are possibly coeval with the volcanic rocks. The igneous rocks lie on a mid-Jurassic magmatic arc which extends across southwestern Arizona and the southwestern part of the GRA (see figure 2B). The arc includes the intrusive rocks with which the well-known porphyry copper deposit at Bisbee is associated.

Following the mid-Jurassic, the magmatic arc moved west (Coney and Reynolds, 1977) and in southwestern Arizona Late Mesozoic clastic beds were 

deposited. These crop out extensively to the south of the GRA, particularly in the Trigo, Castle Dome and the Plomosa Mountains and Livingston Hills. They are described in general by Reynolds (1980) and in some detail in the Plomosa Mountains by Robinson (1980) and Harding (1980). The basal sequence of the sediments is described by Robinson (1980) and consists of red beds that are about 3000 feet thick. They consist of conglomerate (5\%), sandstone $(25 \%)$, siltstone (15\%), mudstone $(40 \%)$ and limestone with gypsum (15\%), all a characteristic red color and deposited in a cyclothemic pattern. The red beds are interpreted to have been deposited by a meandering stream entering into a playa environment where the periodic evaporation precipitated the limestone and gypsum. The red beds rest disconformably on the mid-Mesozoic volcanics and are probably Late Jurassic to Early Cretaceous. They are derived from Paleozoic sediments, probably transported from the Mogollon Highl ands (see fig. 2B).

The red beds are conformably overlain by the Livingston Hills Formation which is described to the south of the GRA in the Plomosa Mountains and in the Livingston Hills by Harding (1980). The formation ranges in thickness from at least 5700 feet in the Plomosa Mountains and at least 10,800 feet in the Livingston Hills, with the top not exposed in either area. In both areas the lower third of the formation is dominated by conglomerate, the middle third by sandstone, and the upper third by siltstone. The formation contains quartzite and carbonate clasts of Paleozoic provenance, and in the upper part, silicic volcanic and granitic clasts, probably of mid-Mesozoic magmatic arc provenance.

In the Bill Williams GRA, Mesozoic rocks crop out in the northern Plomosa Mountains. In this area the Mesozoic rocks are not differentiated and have been metamorphosed to schists. In the Granite Wash Mountains, to the southeast of the GRA, metamorphic structures in similar Mesozoic rocks 
are cut by a Laramide pluton (Rehrig and Reynolds, 1980), indicating that the metamorphism and folding is pre-Laramide.

\section{Laramide Orogenic Period}

The Laramide was a period of volcanism, intrusion and intense tectonic activity in southern Arizona. It is of particular importance because a large number of porphyry copper deposits were formed at this time, especially in southeastern Arizona (see, for instance, Damon and Mauger, 1966; Shafiqullah et al., 1980; Heidrick and Titley, 1982; and fig. 2C, this report). The magmatic and tectonic activity took place during the southeastward sweep of the magmatic arc, possibly as a result of the decrease in the dip of the Benioff zone (Coney and Reynolds, 1977; Clark et al., 1982).

In the Bill Williams GRA, Laramide intrusions are found in the Whipple Mountains and Harcuvar metamorphic core complexes. In the Whipple Mountains, the Laramide intrusives are synkinematic with mylonitization associated with emplacement of the metamorphic core complex (Davis et al., 1980). The intrusives include foliated biotite granodiorite, two-mica adamellite, a garnet-two-mica adamellite and a two-mica tonalite. The rocks are calc-alkaline and peraluminous. In the Granite Wash Mountains immediately to the southeast of the Buckskin sub-area, and on the southwest flank of the Harcuvar metamorphic core complex, Laramide granitic intrusives are locally foliated, contain xenoliths of gneiss and are cut by garnet- and muscovitebearing pegmatites and aplites (Rehrig and Reynolds, 1980). To the south of the GRA in the Gunnery Range, a two-mica granite of the Gunnery Range batholith is also of Laramide age (Shafiqullah et al., 1980). Most of these Laramide intrusives in southwestern Arizona appear to have at least some characteristics of S-type granites as described by Chappell and White (1974).

In the Granite Wash Mountains the granitic rocks intrude metamorphosed 
and folded Mesozoic rocks and thus post-date an earlier Mesozoic episode of folding and metamorphism. In the Whipple Mountains, the granitic intrusives are coeval with the early stages of the emplacement of the metalnorphic core complex.

\section{Metamorphic Core Complexes}

More than a dozen metamorphic core complexes have been identified and described recently in southwestern Arizona. They occur along a northwest-trending zone that extends from southeastern to west-central Arizona, and are part of a more extensive zone that runs from Sonora to Arizona, through eastern Nevada, Idaho, eastern Washington and southeastern British Columbia (Coney, 1980). Their general features have been summarized recently by Davis and Coney (1979) and Reynolds (1980), as follows. Metamorphic core complexes are characterized by metamorphic and mylonitic rocks whose gently dipping foliation defines broad domes which generally are elongated in a ENE to NE direction. The core of the domes consists of amphibolite facies gneisses and granite that have undergone ductile deformation. Up section, a mylonitic fabric with an ENE to NE lineation is overprinted on both igneous and metamorphic rocks. This grades upward into a greenschist facies breccia over a short distance and records a sharp thermal and strain gradient. The breccia is overlain by a narrow decollement zone or dislocation plane above which allochthonous, deformed, but unmetamorphosed upper plate rocks are present. These range in age from Precambrian to Miocene and have undergone listric normal faulting as recently as mid-Miocene. The core complexes typically record 30-20 m.y.B.P. K-Ar cooling ages. It is generaliy agreed that the complexes formed in an extensional environment (back-arc spreading?) during and after the fast regression of the magmatic arc 40-20 m.y.B.P. (Coney and Reynolds, 1977) at a time of high heat 
flow. Davis and Coney (1979) regard the complexes as megahoudins formed from crystalline basement. Rehrig and Reynolds (1980) agree that the complex formed by an extensional process but consider that the metamorphic core complex itself develops between separating blocks.

In the Bill Williams GRA, metamorphic core complexes are present in the Whipple Mountains and in the Buckskin and Rawhide Mountains. In the Whipple Mountains, the geology of the core complex has been described by Davis et al. (1980). The lower plate core rocks consist of amphibolite facies quartzofeldspathic gneiss, foliated calc-alkaline plutons and amphibolite, intruded by hornblende-biotite-two-mica adamellite. Upwards in the section these rocks become progressively mylonitized and are intruded by synkinematic calc-alkaline plutons of adamellite to tonalitic composition. For up to 1000 feet below the detachment surface, brittle deformation predominates and a chlorite and epidote-bearing breccia is present. The upper plate rocks consist of Precambrian crystalline basement including gneiss, amphibolite and granite, and mid-Tertiary volcanics and valley-fill sediments.

In the Buckskin Mountains, the geology of the metamorphic core complex has been described by Shackelford (1977), Davis et al. (1980), and Rehrig and Reynolds (1980). The core rocks consist of quartzofeldspathic gneiss and schist, quartzite, marble, and foliated granitic rocks. Upward in the section, these rocks are affected by a gently dipping mylonitic fabric which becomes progressively brecciated and chloritic as the detachment zone is approached. The upper plate rocks in the Buckskin and Rawhide Mountains consist of Precambrian crystalline basement including gneiss, amphibolite and granite; Paleozoic metasediments including marble, quartzite and phyllite; Mesozoic rocks including metavolcanics, conglomerates and phyllites; and mid-Tertiary volcanics and valley-fill sediments. 



\section{Mid-Tertiary}

Mid-Tertiary rocks are here defined to include all sedimentary and igneous rocks deposited after the Laramide orogeny and the post-Laramide period of peneplanation and before Basin and Range-type faulting became dominant. These pre-Basin and Range rocks have been divided into three units by Eberly and Stanley (1973) and Scarborough and Wi1t (1979).

The lowest unit consists of indurated red to brown arkosic fluvial sandstone, fanglomerates of gneissic and granitic orovenance up to 300 feet thick, and minor lacustrine sediments with some algal limestone. Andesitic to rhyolitic volcanics increase in abundance towards the upper part of this unit.

The middle unit is characterized by voluminous intermediate to felsic volcanism that is associated with the mid-Tertiary orogeny. The volcanics consist of flows, ash flow tuffs, tuff breccias and ash of latitic, quartz latitic, rhyolitic and trachytic composition, and flows and flow breccias of basaltic, basaltic andesite and andesitic composition (Reynolds, 1980). Small intrusions of the above compositions are also present. The volcanic rocks are interbedded with red sand and gravel fluvial deposits, massive fanglomerates and lacustrine deposits with local organic-rich facies, algal limestones and water-laid tuffs. It is within such beds that the well-known Anderson Mine is located (Sherborne et al., 1979).

The upper unit consists of grayish brown poorly consolidated sandstones, fanglomerates, mudstones and water-laid tuffs. The rocks contain abundant volcanic debris and are overlain and intercalated with basaltic volcanics. Mudstones in lacustrine deposits contain fresh water ostracods.

The mid-Tertiary rocks rest unconformably on Precambrian, Paleoznic, Mesozoic and Laramide rocks. They were deposited in northwest-striking 
basins which were tilted north-eastward and southwestward as shown in figure 2D (Scarborough and Wilt, 1979).

The mid-Tertiary volcanic rocks lie mainly in the middle unit but they do extend into the lower and upper units. The volcanism was extremely voluminous and in southwestern Arizona about a million cubic kilometers were uplifted (Shafiqullah et al., 1980). These may have been largely emptied from cauldrons such as have been identified in the Datil volcanics in southwestern New Mexico by Elston (1978) and Elston and Bornhorst (1979). However, no such cauldrons have been identified in southwestern Arizona to date. The volcanism lasted from 35 m.y.B.P. to about 12 m.y.B.P., with the interval between 24 and 12 m.y.B.P. being the transition from the mid-Tertiary orogeny to Basin and Range faulting, which did not take place simultaneously throughout southwestern Arizona (Shafiqullah et al., 1980). In western Arizona, the intensity of volcanism peaked about 21 m.y.B.P. as the volcanic arc swept from east to west during the steepening of the Benioff zone in the late 0ligocene and early Miocene (Coney and Reynolds 1977). At first the volcanism was calc-alkaline, but as the main magmatic arc passed westward volcanism became highly potassic with eruption of potassic trachyandesites and ultra-potassic trachytes (Shafiqullah et al., 1980). Towards the close of the mid-Tertiary orogeny volcanism became almost entirely basaltic.

Mid-Tertiary rocks crop extensively in the Bill Williams GRA. Sediments crop out in the upper plates of the Whipple Mountain and Harcuvar metamorphic core complexes, in the northern part of the Plomosa Range, and they probably are present at depth in the basins that underlie Dutch Flat and the vicinity of Lake Havasu in the Havasu sub-area and Butler Valley and Cactus Plain in the Buckskin sub-area.

In the Whipple Mountains, the Tertiary sediments have been sub-divided 
into the Gene Canyon Formation and the Copper Basin Formation (Davis et al., 1980). The Gene Canyon Formation is nearly 2000 feet thick and consists of red to buff sandstone, andesitic debris flows, siltstone and minor limestone. The formation rests unconformably on crystalline Precambrian rocks. The Copper Basin Formation is nearly 2500 feet thick and consists of red sandstone, conglomerate and siltstone interbedded with andesitic volcanic rocks. It rests unconformably on the Gene Canyon Formation. Both formations contain clasts of mylonitic gneisses and are affected by listric normal faulting that is associated with emplacement of the metamorphic core complexes. The formations are therefore coeval with the core complexes.

In the Rawhide and Buckskin Mountains, the Tertiary rocks consist of coarse breccia, conglomerate, sandstone, siltstone, limestone and volcanic rocks of the Chapin Wash and Artillery Formations, which according to Rehrig and Reynolds (1980) are correlative with the Copper Basin Formation in the Whipple Mountains.

In the west-central part of the Buckskin sub-area near the town of Parker the Tertiary rocks have been examined by Scarborough and Wilt 11979; see figs. 1 and 3). Here, up to 6000 or 7000 feet of red to brown arkosic sands with minor thin gravel lenses rest on a detachment surface above mylonitic gneisses. The sediments are locally known as the "Osborne Redbeds". They are interbedded with andesite flows, they are in fault contact with younger rhyolitic pyroclastic deposits and are overlain by basalts dated at 16 to 20 m.y.B.P..

About 10 miles to the east of the Buckskin sub-area, near Artillery Peak (fig. 1), some 2000 feet of the Artillery Formation are exposed (Scarborough and wilt, 1979). Here the formation consists of 150 feet of basal red arkosic conglomerate which is overlain by a mainly lacustrine sequence of multi-colored shale and mudstone interlayered with lesser limestone and 

sandstone. The formation rests unconformably on a Precambrian(?) granite.

In the Plomosa Mountains, just to the south of the Buckskin sub-area (fig. 1), the Tertiary sediments rest unconformably on Precambrian gneiss. They consist of 100 feet of basal arkose, 200 feet of thinly-bedded calcareous shale and limestone, several hundred feet of andesitic flows and a capping of rhyolitic welded tuff (Scarborough and Wilt, 1979). The beds dip south and are overridden by a thrust sheet of Mesozoic schist.

The mid-Tertiary rocks also underlie most of the valley-fill sediments that were deposited in basins during and after Basin and Range faulting (Eberly and Stanley, 1978). Based on interpretation of drill hole and seismic profile data, Eberly and Stanley (1978) showed that most of the basins to the east and south of the GRA are underlain by over 1000 feet and up to 6000 feet of mid-Tertiary sediments and volcanics. The basins underlying Dutch Flat, Havasu Lake area, Butler Valley and Cactus Plain are thus likely to also be underlain by mid-Tertiary rocks.

Mid-Tertiary volcanic rocks crop out on the southwest side of the Mohave and Bill Williams Mountains in the Havasu sub-area and in the west-central and south-central Buckskin sub-area. They are mainly andesitic in composition and probably consist of flows and breccias. Tertiary basalts are present in the Parker area in west-central Buckskin sub-area.

\section{Late Tertiary}

Late Tertiary deposits are found in all the tectonic basins formed during the Basin and Range disturbance. The depths of these basins has been estimated by Oppenheimer and Sumner (1980) through gravity modeling and drill-hole data and is shown in figures 3 and 4 , and summarized in figure 1 , of this report. The depths of these basins is highly variable but those that are deeper than 800 feet include Dutch Flat and the area near Lake Havasu in 
the Havasu sub-area, and the Cactus Plain and the Butler Valley in the Buckskin sub-area.

The deposits consist mainly of poorly consolidated, tan-colored fanglomerate, sandstone and siltstone of fluvial and lacustrine origin and lesser basaltic and silicic volcanics (Scarborough and Wilt, 1979; Reynolds, 1980). In the Parker area along the Colorado River, marine sediments of the Bouse Formation are present (Metzger, 1967, 1968). The sediments consist of a basal limestone which contains foraminifera, mollusks, ostracods, charophytes and barnacles and is up to 100 feet thick. This is overlain by about 200 feet of claystone interbedded with silt, fine sand and gravel. The claystone is pale olive and swells when moistened. These sediments were deposited in an embayment of the Gulf of California during the Pliocene.

The Late Tertiary sediments rest unconformably on Mid-Tertiary rocks. In the Parker area, the Bouse Formation rests on a fanglomerate (Metzger, 1967) which may be the clastic upper unit of the Mid-Tertiary sequence.

The initiation of Basin and Range faulting and deposition of basin-fill sediments took place 13-12 m.y.B.P. according to Eberly and Stanley (1978). Shafiqullah et al. (1980), however, present evidence to show that the transition from the mid-Tertiary orogeny to the Basin and Range disturbance took place over the time interval between 19 and 12 m.y.B.P. and that volcanism decreased in intensity from 9 to $4 \mathrm{~m} \cdot y \cdot B . P$. The interval during which Basin and Range tectonism volcanic activity and sedimentation was dominant in southwest Arizona was probably 14-4 m.y.B.P. (Shafiqullah, 1980), though some volcanism is as young as 1 m.y.B.P.. The volcanism associated with Basin and Range faulting is mainly basaltic but in the Bill Williams GRA considerable Late Tertiary silicic volcanism is also present. Little is known about these volcanics, but they could be related to the garnet-and topaz-bearing rhyolites reported by Burt et a1. (1981) from the Burro Creek 
area near the Anderson Uranium Mine, to the east of the Buckskin sub-area. These rhyolites are enriched in $F, B e, L i, R b, S r$ and possibly $U$, and could be good source rocks for uranium in the nearby sedimentary basins. According to Suneson and Lucchitta (1979), the silicic volcanics were erupted 15.1 to 10.3 m.y.B.P. along a northwest-trending lineament known as the "Aubrey Lineament" which marks the northeasterly margin of metamorphic core complexes in southwestern Arizona. The silicic volcanics were erupted together with basalts and they constitute a bimodal volcanic suite. The silicic volcanics overlie and are interbedded with a distinctive red arkosic conglomerate (Suneson and Lucchitta, 1979).

\section{Late Tertiary and Quaternary}

During the last $4 \mathrm{~m} \cdot \mathrm{y}$. volcanic and tectonic activity has slowed down in southwestern Arizona. The dominant geological processes have been erosion of ranges and formation of extensive pediments, deposition of fanglomerates and deposition of alluvium, mainly along the Colorado River.

\section{STRUCTURAL GEOLOGY}

The GRA lies within the North American craton and east of the Wasatch line, and has been affected by tectonism during Proterozoic, mid-Mesozoic, Laramide and mid-Tertiary orogenies and most recently, by the Basin and Range disturbance. The area is therefore structurally very complex. It is only recently, and largely as a result of detailed structural studies and radiometric dating, that the structure and tectonics of the area has begun to be understood. Particularly important recent studies include strain analysis of various deformations by Davis (1981) and a summary of recent radiometric dates by Shafiqullah et al. (1980).

During the Arizonan revolution, 1.76 to 1.63 b.y.B.P. (Damon, 1968), the Precambrian rocks were folded about ENE striking axes and underwent $N-S$ to 
NNW faulting (Davis, 1981). The Colorado lineament (fig. 2A), a major strike slip system according to Warner (1978), was initiated about this time and its southwestern extension passes through the GRA.

No pronounced tectonic or igneous activity took place during the Paleozoic, but southwestern Arizona was strongly affected by a mid-Mesozoic magmatic arc and a later period of metamorphism and folding. The magmatic arc extended across southwestern Arizona and the southwestern part of the GRA (see fig. 2B) during the mid-Jurassic and produced voluminous volcanism and granitic plutonism. The area underwent folding and metamorphism after deposition of molasse-like sediments and prior to the Laramide orogeney. Northwest-trending strike slip faulting was initiated (Davis, 1981) and movement along the Mohave-Sonora left-lateral megashear (see fig. 2B) partially took place at this time (Silver and Anderson, 1974). Northwest-trending linear discontinuities in depositional patterns (see fig. 2B) were produced in southeastern Arizona (Titley, 1976).

The Laramide was a period of intense tectonism and localized magmatic activity which were associated with the southeastward migration of the magmatic arc (Coney and Reynolds, 1977; Lowe11, 1974). The Laramide basement-cored uplifts and thrust faults which strike NNW to NW (Nielsen, 1979; Davis, 1981); the WNW left lateral strike slip faulting of the Texas zone of Schmitt (1966); and the ENE striking tensional features (Rehrig and Heidrick, 1976) are all probably related to ENE plate motion and compression. Laramide plutons associated with porphyry copper mineralization have a pronounced NNW to NW trend and a secondary ENE trend (Heidrick and Titley, 1982, see fig. 2C). The former is parallel to the Laramide magmatic arc and basement cored uplifts, and the latter parallel to Precambrian fold axes and Laramide tensional features. The major NNW to NW porphyry copper trend may overlap the northeast corner of the Bill Williams GRA (see fig. 2C). 

The mid-Tertiary orogeny lasted approximately from 34 to 14 m.y.B.P. (Shafiqullah et al., 1980), and involved eruption of large volumes of volcanic rocks, emplacement of metamorphic core complexes and listric normal faulting. These geologic events accompanied the steepening of the Benioff zone and the resultant westward migration of the magmatic arc at this time (Coney and Reynolds, 1977).

The volcanism produced enormous volumes of ignimbrite eruptions and was dominantly calc-alkaline but became potassic in the later stages. In southwestern New Mexico, similar volcanics originated from numerous cauldrons (Elston and Bornhorst, 1979). Cauldrons may be present in southwestern Arizona though none have been located to date. Thick sections of volcanics in the northwestern part of the GRA suggest that such structures could be present there.

The metamorphic core complexes are characterized by mylonitic augen gneiss and an overlying brittle fracture zone separated by a dislocation surface from an allochthonous upper plate which is unmetamorphosed (Davis and Coney, 1979; Coney, 1980; Rehrig and Reynolds, 1980). The mylonitic foliation defines gently dipping NE- to ENE-striking domes which have physiographic expression. The mylonitic rocks have a pronounced NE to ENE lineation which is developed parallel to the direction of extension in the lower plate. Most workers agree that metamorphic core complexes indeed formed as a response to extension in a NE-SW to ENE-WSW direction. Davis (1980) considers the complexes as mega-boudins, whereas Rehrig and Reynolds (1980) consider that the complexes developed in areas of high heat flow between separating blocks. The relationship of the core complexes to the coeval volcanism is not known. Metamorphic core complexes are present within the Whipple, Rawhide and Buckskin Mountains in the Bill Williams GRA.

Listric normal faulting is common in the upper plates of metamorphic 

core complexes. The faults merge downward into the dislocation surface. The faults generally strike northwest, are spoon-shaped, gravity-like faults that typically involve 01 igocene to mid-Miocene rocks (Davis, 1981).

About 14 m.y.B.P. a transition occurred between listric faulting and Basin and Range normal faulting. Basin and range faults strike NW to NS, and are high angle faults (Davis, 1981). The present day ranges and basins result from this tectonic episode which was terminated in much of southwestern Arizona about 4 m.y.B.P.

\section{Geologic History}

The geologic history of the area is long and complex, and only a brief synopsis is presented here. Excellent summaries of the main geological events that affected the southern North American Cordillera are given by Burchfiel (1979) and Dickinson (1981). More detailed accounts pertaining particularly to southwestern Arizona are given by Shafiquilah et al. (1980) and Reynolds (1980). The geologic history is summarized pictorially in figure 6 and can be described as follows:

1. Volcanic and clastic rocks were accreted onto the North American Craton 1.8 to 1.6 b.y.B.P. from the southeast (Anderson, 1976; Anderson and Silver, 1976; Silver, 1978; Titley, 1982). The boundary between the dominantly volcanic and volcaniclastic Yavapai series and the metavolcanic gneissic rocks approximately coincides with the Bright Angel-Mesa Butte linear (Titley, 1982; see fig. 2a), the extension of which passes through the Buckskin sub-area of the GRA. The rocks were folded about northeasterly axes, metamorphosed and intruded by granites 1.7 to 1.6 b.y.B.P. (Damon, 1968), and then intruded by anorogenic granites 1.5 to 
1.4 b.y.B.P. (Damon, 1968; Silver et al., 1977).

2. Some time after this the area was uplifted and eroded. The area to the east of the GRA was submerged beneath epicontinental seas, and shallow marine clastic sediments and minor carbonates of the late Proterozoic Apache Group were deposited. Apparently at this time the area covered by the GRA remained above sea level.

3. During the Cambrian, the GRA area was submerged beneath epicontinental seas, and shallow marine sandstones and sandy mudstones were deposited (Miller, 1970; Reynolds, 1980).

4. No deposition took place during the Ordovician and Silurian, and the Cambrian is disconformably overlain by a thick sequence of Devonian to Permian shallow marine carbonates and sandstones (Miller, 1970; Reynolds, 1980).

5. During the mid-Mesozoic a magmatic arc extended over the southwesern part of the GRA (see fig. 2b) and produced voluminous intermediate to felsic volcanics and minor intrusives (Reynolds, 1980). The Benioff zone then steepened, the magmatic arc moved west (Coney and Reynolds, 1977), and a thick sequence of continental molasse-like sediments, some of which are distinctly red, were deposited (Robinson, 1980; Harding, 1980). The Mesozoic volcanics and sediments were folded and metamorphosed prior to the Laramide (Rehrig and Reynolds, 1980).

6. The Laramide was a period of intense tectonic activity characterized by NNW to NW-trending basement-cored uplifts and thrust faults (Nielsen, 1979; Davis, 1981); WNW-trending left-lateral faults of the Texas zone (Schmitt, 1966); 

ENE-striking tensional features (Rehrig and Heidrick, 1976); and intrusion of granitic plutons, which in southeastern Arizona are epizonal and are located along NW and ENE trends (Heidrick and Titley, 1982). In southwestern Arizona and in the GRA, the Laramide plutons crystallized at moderate depths and have characteristics of S-type granites. In the GRA they were associated with the early stages of metamorphic core complex emplacement. The Laramide magmatic activity proceeded from northwest to southeast as the dip of the Benioff zone flattened during the time interval from 70 to 50 m.y.B.P. (Coney and Reynolds, 1977).

7. The Laramide was followed by a period of tectonic quiet during which erosion proceeded.

8. The mid-Tertiary orogeny lasted from about 35 to 14 m.y.B.P. During this time a great thickness of fluvial and lacustrine sediments interbedded with voluminous felsic to intermediate volcanics were deposited in northwest-striking basins (Eberly and Stanley, 1978; Scarborough and Wilt, 1979; see fig. 2D). The volcanism was calc-alkaline to potassic (Shafiqullah et al., 1980), and was dominated by ignimbrite eruptions possibly related to cauldrons. Coeval with the volcanism was the emplacement of metamorphic core complexes which occur along a northwest-trending zone (Coney, 1980) which passes through the GRA. Associated with the core complexes and also present el sewhere in southwestern Arizona, are listric normal faults (Davis, 1981) which offset the mid-Tertiary volcanic and sedimentary rocks. Volcanism and tectonism migrated westward during the mid-Tertiary, as the dip of the Benioff zone 

steepened (Coney and Reynolds, 1977).

9. After the westward passage of the magmatic arc, listric faulting gave way to steep, normal Basin and Range faulting which became dominant after about 14 m.y.B.P. (Shafiqullah et al., 1980). At this time volcanism became mainly basaltic, but to the northeast of the metamorphic core complexes it was bimodal (Suneson and Lucchitta, 1979). The present ranges were uplifted and the basins were filled with fluvial, lacustrine, and near Parker, marine sediments.

10. Since 4 m.y.B.P. volcanism and tectonism have been very minor (Shafiqullah et al., 1980) and the dominant geologic process has been erosion of ranges with formation of extensive pediments, and deposition of extensive fans in the basins and flood plain deposits near major rivers.

\section{Paleontologic Documentation}

Paleontological documentation is important for three major reasons, as follows:

A. guide fossils, which in the sedimentary sequence are most useful for stratigraphic correlation,

B. outstanding fossil specimens or fossils which are extraordinarily preserved can be beneficial to science and/or tourism, and

c. fossils can be excellent indicators of the paleogeographic and paleoecological environments; as a result, even moderately to poorly preserved, "uninteresting" fossils can be important geologically.

Plant fossils must also be considered important as organic material can trigger the precipitation of uranium and other metals. 
The following is a brief summary of the sedimentary formations of the Bill Williams GRA and its enclosed WSAs, including a list of fossils known to occur in those rocks. To the authors' knowledge, there are no fossil localities of outstanding importance or interest. A list of some of the more common and abundant marine fossils of Arizona is provided by Wilson (1962, p. 111-112) and may include some fossils found in the area. Unfortuantely, little specific information has been reported about fossils occurring in rocks of the Bill Williams GRA.

No fossils are reported to occur in the Cambrian Bolsa Quartzite. Heindl and McClymonds (1964) state that trilobites are known to occur in other areas of outcrop of the Cambrian Abrigo Formation, which is comprised of sandy shale interbedded with quartzite. Outside of the Kofa GRA, the Martin Formation of Devonian age is divided into two members, a lower member containing coalified plant material and a brachiopod, gastropod, ostracod and fish bearing upper member (Teichert, 1965). The Mississippian Escabrosa Limestone contains crinoids, coral, bryozoans and brachiopods in other areas of outcrop in Arizona. The quartzite and interbedded limestone and mudstone of the Pennsylvanian-Permian Supai Formation is not reported to be fossil-bearing in this region, as is true of the Permian Coconino Sandstone and Kaibab Limestone. In the Bill Williams GRA, Paleozoic sediments, with no reported fossil occurrences, crop out in the Gibraltar Mountain (050-012), Planet Peak (050-013) and Swansea (050-015A) WSAs.

Mesozoic sediments of the GRA include mid-Mesozoic volcanic conglomerate, sandstone and red mudstone and late Mesozoic clastics. The late Mesozoic clastics are comprised of cyclothemic basal red beds of fluvial and playa deposition and the conformable conglomerate, sandstone and siltstone of the Livingston Hills Formation. No Mesozoic sediments crop out in any of the WSAs of the Bill Williams GRA. 

Sediments of the lowest mid-Tertiary unit of Eberly and Stanley (1978) and Scarborough and Wilt (1979) include algal limestones. Sediments which are interbedded with volcanics of the middle unit include lacustrine deposits with local organic-rich facies as well as algal limestones. Mudstones of the upper unit are reported to contain fresh water ostracods in other parts of Arizona. Late Tertiary sediments, comprised of poorly consolidated fanglomerate plus sandstone and siltstone of fluvial lacustrine origin, are not known to contain fossils. Mid- and late Tertiary rocks which may contain some of the above-mentioned sediments and fossils crop out in all the WSAs except the Needles Eastern Extension (050-005B) WSA. The Pliocene Bouse Formation, a marine unit with foraminifers, mollusks, ostracods, charophytes, and barnacles, crops out near the Gibraltar Mounain (050-012) WSA.

Late Tertiary and Quaternary fanglomerates and alluvium are not known to contain fossils. These sediments occur in all the WSAs except the Needles Eastern Addition (050-005B) WSA.

\section{ENERGY AND MINERAL RESOURCES}

\section{Known Mineral Deposits, Mines or Prospects with Recorded Production}

1. Planet Mine Location:

Commodities: Production: References:

\section{Cienga} Location:

Commodity:

Ore Materials: Gold present in base-metal sulfide minerals. Deposit description and geology: Production: More than 10,000 oz. Au produced. References: Base-metal sulfides replace limestone.

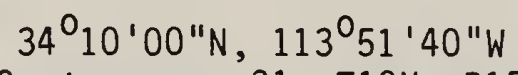

$34^{\circ} 15^{\prime} 20^{\prime \prime} \mathrm{N}, 114^{\circ} 07^{\prime} 30^{\prime \prime} \mathrm{W}$

NW $1 / 4$ sec. $34, T 11 \mathrm{~N}, \mathrm{R} 18 \mathrm{~W}$

location derived from Arizona Bureau of Mines Bulletin 180

$$
\text { Butletin } 180
$$
USGS, CRIB Mineral Resources File 12, Record 2660 , p. 6761; Arizona Bureau of Mines Bulletin 180 . 

4. Dobbins Claims
Other names:
Location:
Jolly Roger
Comodity:
Ore Haterials: Pyrolusite, psilomelane.
Deposit Description: $33^{\circ} 56^{\prime} 43^{\prime \prime} \mathrm{N}, 113^{\circ} 55^{\prime} 23^{\prime \prime} \mathrm{W}$
Sec. $15, T 7 N, R 16 \mathrm{~W}$

Small $N 65^{\circ}$ E striking, NW dipping tabular shaped ore body.

Geology :

Mineralization along a shear zone in Tertiary andesite. Manganese minerals cement the fault

Production: breccia and rep?ace andesite fragments.

References: $\quad$ USGS CRIB Mineral Resources File 12, Record 2774, $p$. 7073-7075.

\section{Little Butte Copper Mine}

\section{Other Names: \\ Location:}

Arjzona Pride

$33^{\circ} 57^{\prime} 50^{\prime \prime} \mathrm{N}, 114^{\circ} 03^{\prime} 15^{\prime \prime} \mathrm{W}$

Sec. 7 and $8, T 7 N, R 17 W$

Commodities: $\mathrm{Au}$, (major product); $\mathrm{Cu}, \mathrm{Ag}$ (minor product); $\mathrm{Fe}, \mathrm{Mn}$. Ore Materials: Chrysocolla, malachite, hematite, specularite.

Deposit description and geology:

Sma11, irregularly shaped deposit is in 1 imestone and granite intruded by Tertiary diabase.

Underground workings.

Production: Yes, 5800 tons through 1955, $0.45 \mathrm{oz} / \mathrm{T} \mathrm{Au}, 0.16 \mathrm{oz} / \mathrm{T}$ $\mathrm{Ag}, 2 \% \mathrm{Cu}$.

Reference: USGS CRIB Mineral Resources File 12, Record 2776, p. 7078-7080; Keith, 1978

Note:

Latjtude and longitude $\left(24^{\circ} 57^{\prime} 18^{\prime \prime}\right.$,

$114^{\circ} 18^{\prime} 42^{\prime \prime} W$ ) given in USGS CRIB is obviously

wrong, location given is PLS location given in the CRIB and confirmed by geology and symbol on topographic map.

\section{Blue Slate Mine}

Location: $\quad 33^{\circ} 57^{\prime} 54^{\prime \prime} \mathrm{N}, 114^{\circ} 04^{\prime} 08^{\prime \prime} \mathrm{W}$

Commoditites: $\mathrm{Au}$ (major product); $\mathrm{Cu}, \mathrm{Ag}$ (minor products), $\mathrm{Fe}$ (occurrence).

Ore Materials: Gold, copper stain, hematite, limonite.

Deposit Description:

Vein is a maximum of 2 feet wide and strikes $\mathrm{N} 20^{\circ} \mathrm{W}$, dipping $\mathrm{NE}$. Workings: 2 shafts and open cuts.

Geology: Deposit is along a fault zone in Cretaceous metamorphosed shales intruded by Tertiary diorite porphyry.

Production: $\quad 130$ tons of ore containing $3 \% \mathrm{Cu}, 1 \mathrm{Oz} \mathrm{Au} / \mathrm{T}$ and traces of $\mathrm{Ag}$ were removed.

References: $\quad$ USGS CRIB Mineral Resources File 12, Record $2777, p$. 7081-7083, Keith, 1978. 

8. Dutchman Mine

Other Names:

Location:

Flying Dutchman

$33^{\circ} 57^{\prime} 17^{\prime \prime} \mathrm{N}, 114^{\circ} 04^{\prime} 32^{\prime \prime} \mathrm{W}$

Sec. 7 and 18 , T7N, R17W

Commodities: $\mathrm{Au}$ (major product); $\mathrm{Cu}, \mathrm{Ag}$ (minor products); $\mathrm{Fe}$ (occurrence).

Ore Materials: Gold, hematite, Cu-stain.

Deposit description:

Small vein. Workings: shaft.

Geology: Mineralization is along a steeply dipping fault zone in Cretaceous shales that have been intruded by granite porphyry.

Production: $\quad 1050$ tons up t.o $1941,0.802 \mathrm{oz} \mathrm{Au} / \mathrm{T}, 1 \% \mathrm{Cu}, 0.1 \mathrm{oz}$ $\mathrm{Ag} / \mathrm{T}$

Reference: $\quad$ USGS CRIB Mineral Resources File 12, Record 2778, p. 7084-7086; Keith, 1978.

\section{01d Maid Mine}

Location: E center sec. 13, T7N, R18W

Comnodities: $\mathrm{Al}, \mathrm{Ag}, \mathrm{Cu}, \mathrm{Fe}$

Ore Materials: Gold, hematite, oxidized copper minerals.

Deposit Description:

Vein with maximum thickness of 3 feet, trends $N$ and dips $60 \%$ W. Workings: underground.

Geology: Mineralization is in a complexly faulted vein in Cretaceous shales which have been intruded by granite porphyry.

Production: $\quad 150$ tons in the early $1900^{\prime} \mathrm{s}-1938,2.6 \mathrm{oz} \mathrm{Au} / \mathrm{T}, 0.6$ $0 \mathrm{z} \mathrm{Ag} / \mathrm{T}$ and $0.1 \% \mathrm{Cu}$.

References: USGS CRIB Mineral Resources File 12, Record 2779, p. 7087-7089; Keith, 1978.

11. Mammoth Prospect

Synonym name: Corona Copper Company

Location:

$34^{\circ} 03^{\prime} 38^{\prime \prime N}, 113^{\circ} 46^{\prime} 13^{\prime \prime} \mathrm{W}$

Sec. 1,12 and 13, T8N, R15W

Commodities: $\quad \mathrm{Cu}$ (major product); $\mathrm{Au}, \mathrm{Ag}$ (minor products); $\mathrm{Fe}, \mathrm{Ba}$, $F$ (occurrences).

Ore materials: Cu-silicate, Fe-oxide, barite, fluorite.

Deposit description:

Yes, $1890^{\prime} \mathrm{s}$ and early $1900^{\prime} \mathrm{s}, 16 \% \mathrm{Cu}, 0.8 \mathrm{oz} \mathrm{Au} / \mathrm{T}$, $1.3 \mathrm{oz} \mathrm{Ag} / \mathrm{T}$.

References: $\quad$ USGS CRIB Mineral Resources File 12, record 2788, p. 7113-7115; Keith, 1978.

\section{Copper Glance Mine}

Synonym names: Corona Copper Company, Mammoth Group

Location:

$34^{\circ} 03^{\prime} 10^{\prime \prime} \mathrm{N}, 113^{\circ} 4^{\prime} 28^{\prime \prime} \mathrm{W}$

Sec. 12 , T8N, R15W

Commodities: $\mathrm{Cu}$ (major product); $\mathrm{Au}, \mathrm{Ag}$ (minor products); $\mathrm{Ba}, \mathrm{Fe}$ (occurrences).

Ore Materials: Chalcopyrite, Cu-silicate, hematite, magnetite,

Deposit description: gold, silver, barite.

Stringers of 4 inch maximum width, trend $N 52^{\circ} \mathrm{W}$ 


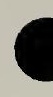

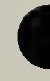

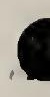


and dipping 60 $\mathrm{NE}$. Workings: inclined shaft.

Geology: Stringers occupy a shear zone in gneiss and schist of the metamorphic core complex which has been intruded by Tertiary pegmatite/aplite dikes.

Production: Yes, small amount.

References: $\quad$ USGS CRIB Mineral Resources File 12, record 2789, p. 7116-7118.

\section{Chicago Prospect}

Other Names: Corona Copper Co., Mammoth Group

Location:

$34^{\circ} 03^{\prime} 13^{\prime \prime} \mathrm{N}, 113^{\circ} 47^{\prime} 03^{\prime \prime} \mathrm{W}$

Commodities: $\quad \mathrm{Cu}$ (major product); $\mathrm{Ag}, \mathrm{Au}$ (minor products); $\mathrm{Ba}, \mathrm{Fe}$ (occurrences).

Ore materials: Chrysocolla, gold, silver, barite, iron.

Deposit description:

Smal1 vein (max. width 4 inches) trends $N 35 W$ and

dips $80^{\circ} \mathrm{NE}$. Ore is present as irregular masses

and vug fillings. Workings: underground.

Geology: Mineralization is along a fault plane in gneiss of the metamorphic core complex which has been cut by pegmatite and aplite dikes. The rock is brecciated, with thin film of barite coating fragments.

Production: Yes, small amount

References: $\quad$ USGS CRIB Mineral Resources File 12, Record 2790, p. 7119-7121.

\section{Moro Mine Group}

Synonym name:

Location:

Big Horn
$34^{\circ} 09^{\prime} 02^{\prime \prime} \mathrm{N}, 113^{\circ} 49^{\prime} 00^{\prime \prime} W$

W $1 / 2$ sec. 3 , T9N, R15W

Commodities: $\quad \mathrm{Cu}$ (major producer); $\mathrm{Au}, \mathrm{Ag}$ (minor products); $\mathrm{Fe}$ (occurrence)

Ore materials: Cu-carbonate, Cu-silicate, leaf gold, specularite, Deposit description: $\mathrm{Cu}$ glance, $\mathrm{Fe}-\mathrm{oxide}$.

Smal1, irregularly shaped deposit. Workings: underground.

Geology: Deposit occurs in conglomerate overlying gneiss.

Production: $\quad 2300$ tons averaging $3 \% \mathrm{Cu}$, minor $\mathrm{Au}$ and $\mathrm{Ag}$.

References: $\quad$ USGS CRIB Mineral Resources File 12, record 2798, D. $7141-7143$; Keith, 1978.

\section{Pride Mine}

Other name: Location:

Arjzona Pride

$34^{\circ} 09^{\prime} 14^{\prime \prime} \mathrm{N}, 114^{0} 02^{\prime} 15^{\prime \prime} \mathrm{W}$

NW $1 / 4$ sec. 4 , T9N, R17W

Commodities: $\mathrm{Au}$ (major product); $\mathrm{Ag}, \mathrm{Cu}$ (minor products); $\mathrm{Fe}$ (occurrence).

Ore Materials: Cu-silicate, azurite, malachite, chalcopyrite,

Deposit description: hematite.

Small replacement bodies. Workings: shaft and several adits.

Geology: Deposit is in thin marble beds at or near 
Production:

References:

intersection with thrust fault which separates marble from underlying metamorphic rocks. Some mineralization is also present along the joint. planes in amphibole schist.

Few tens of tons.

USGS CRIB Mineral Resources File 12, Record 2799, p. 7144-7146, Keith, 1978.

18. Clara Mine

Location:

$34^{\circ} 09^{\prime} 48^{\prime \prime N}, 113^{\circ} 47^{\prime} 36^{\prime \prime} \mathrm{W}$

Sec. 20,26 and 35, T10N, R15W

Commodities: $\quad \mathrm{Cu}$ (major product); $\mathrm{Au}, \mathrm{Ag}$ (minor products); $\mathrm{Fe}$ (occurrence).

Ore materials: Chrysocolla, chalcocite, iron staining, leaf gold and jasper.

Deposit description:

Smal1, irregular and lensing shaped replacement. Workings: consist of a short adit tunnel and adit with a short winze at the end.

Geology: Mineralization in Precambrian granite and gneiss, and in Paleozoic limestone, associated with Tertiary volcanic tuff.

Production: $\quad 1911-1940,50,000$ tons at $4.7 \% \mathrm{Cu}$, minor $\mathrm{Ag}$, Au.

References: $\quad$ USGS CRIB Mineral Resources File 12, record 2808, $p$. 7166-7168; Keith, 1973.

\section{Clara-Swansea Mine}

Synonym name: Signal, Copper Prince

Location:

$34^{\circ} 10^{\prime} 03^{\prime \prime} \mathrm{N}, 113^{0} 50^{\prime} 34^{\prime \prime} \mathrm{W}$

Sec. 29, 32, T10N, R15W

Commodities: $\quad \mathrm{Cu}$ (major product); $\mathrm{Ag}$, $\mathrm{Au}$ (minor products); $\mathrm{Fe}$ (occurrence).

Ore materials: Chalcopyrite, bornite, pyrite, specularite, and hematite.

Deposit description:

Smal1, irregularly shaped replacement. Workings: underground.

Geology: Mineralization in Precambrian gneiss and in fault

block of folded Paleozoic limestone.

Production: $\quad 352,000$ tons of ore at $3 \% \mathrm{Cu}, 0.09 \mathrm{oz} \mathrm{Ag} / \mathrm{T}$, and minor Au.

References: USGS CRIB Mineral Resources File 12, record 2809, $p$. 7169-7170; Keith, 1978.

20. Mystery Hill

Location:

Commodities: $\mathrm{Ag}, \mathrm{F}, \mathrm{Pb}, \mathrm{Au}$.
Ore Materials: Silver, fluorspar, lead and gold.

Sec. 29, T10N, R15W.

Deposit description:

Small vein deposit. Workings: underground.

Production: Yes, small amount.

References: $\quad$ USGS CRIB Mineral Resources File 12, record 2810, $p$. $7172-7173$.

\section{Mineral Hill Mine}


Other names: Continental

Location:

SE $1 / 4 \mathrm{sec}$. 2, NE $1 / 4$ and $E$ cen. sec. 10, NW $1 / 4$ sec. 11, T10N, R17W.

Commodities: $\quad \mathrm{Cu}$ (major product); $\mathrm{Aa}, \mathrm{Au}, \mathrm{Fe}$ (minor products); Be (occurrence).

Ore materials: Chrysocolla, specularite, azurite, and malachite.

Deposit Description:

Small irregular shaped hydrothermal replacement. Workings: underground, short adits, a raise, numerous pits.

Geology: Mineralization in folded and faulted Paleozoic Limestone and 1 imey shale ovelying Precambrian gneiss.

Production: Worked sporadically from early 1900's through 1970 , averageing $1.7 \% \mathrm{Cu}$, minor $\mathrm{Au}$ and $\mathrm{Ag}$.

References: $\quad$ USGS CRIB Mineral Resources File 12, Record 2811, p. 7174-7176; Keith, 1978.

\section{Iron King Mine}

Other name:

Location:

\section{War Eagle}

$34^{\mathrm{O}} 13^{\prime} 16^{\prime \prime} \mathrm{N}, 113^{\circ} 58^{\prime} 47^{\prime \prime} \mathrm{W}$

Sec.12, T10N, R17W

Comodities: $\mathrm{Mn}$ (major product); $\mathrm{Ba}, \mathrm{Fe}$ (occurrence).

Ore materials: Mn oxides, barite, hematite and Fe-oxide.

Deposit description:

Sma11 $N 45^{\circ} \mathrm{W}$-trending, SW dipping, blow outs

shaped replacement. Workings: underground, short tunnels and shallow shaft.

Geology: $\quad$ Mineralization in Precambrian granite gneiss associated with Tertiary basalt flows.

Production: Yes, small amount.

References: $\quad$ USGS CRIB Mineral Resources File 12, Record 2813, p. 7179-7181.

24. Carnation Mine

Other names:

Location:

Empire, Gray Eagle

$34^{\circ} 11^{\prime} 56^{\prime \prime} \mathrm{N}, 114^{\circ} 8^{\prime} 45^{\prime \prime} \mathrm{W}$

Sec. 16, 17 and 21, T10N, R18W

Commodities: $\mathrm{Cu}, \mathrm{Au}$ (major products); Ag (minor product).

Ore materials: Copper carbonate, siderite, and hematite.

Deposit description:

Sma11, irregular lense shaped vein. Workings:

underground.

Geology: Mineralization in Precambrian amphibolitic schists

Production: 8,000 tons.

References: USGS CRIB Mineral Resources File 12, Record 2814, p. 7182-7184; Keith, 1978.

\section{Mardwell and Osbourne Mine}

0 ther name:

Location:

Mammon Copper.

$34^{\circ} 09^{\prime} 38^{\prime \prime N}, 114^{\circ} 07^{\prime} 10^{\prime \prime} \mathrm{W}$

Sec. 34, T1ON, R18W

Commodities: $\mathrm{Cu}$ (major product); $\mathrm{Au}, \mathrm{Ag}, \mathrm{Fe}$ (minor products).

Ore Materials: Hematite, chrysocolla and malachite. 
Deposit Description:

Small, irregular, tabular shaped vein/replacement, S30 $\mathrm{W}$-trending. Workings: underground, adit tunne? and an inclined shaft.

Geology: Mineralization in Precambrian quartz-mica and amphibolitic schists associated with Tertiary tuff and olivine basalt.

Production: 800 tons.

References: $\quad$ USGS CRIB Mineral Resources File 12, Record 2815, D. 7185-7187; Keith, 1978.

\section{Sue Manganese Mine}

Other name:

Location:

Sue Mine

Sec. 23, TION, R19W

Commodities: $\mathrm{Mn}, \mathrm{Cu}, \mathrm{Au}, \mathrm{Ag}$

Ore materials: Chrysocolla, malachite and manganese

Deposit description:

Small $\mathrm{N} 25^{\circ} \mathrm{W}$-trending, $80^{\circ} \mathrm{SW}$ dipping, irregularly shaped vein/shear zone. Workings: underground.

Geology: $\quad$ Mineralization in brecciated zone cutting silicified and metamorphosed Paleozoic limestone and metamorphosed Precambrian rocks.

Production: $\quad 400$ tons at $3.5 \% \mathrm{Cu}, 0.2 \mathrm{oz} \mathrm{Au} / \mathrm{T}, 0.1 \mathrm{oz} \mathrm{Ag} / \mathrm{T}$.

References: $\quad$ USGS CRIB Mineral Resources File 12, Record 2816, $p$. 7188-7190; Keith, 1978.

\section{Billy Mack Mine} Other name: Location:

Ruby
$34^{\mathrm{O}} 11^{\prime} 19^{\prime \prime} \mathrm{N}, 11 \mathrm{w}^{\mathrm{O}} 11^{\prime} 27^{\prime \prime} \mathrm{W}$

Sec. 24, T10N, R19W

Commodities: $\mathrm{Cu}, \mathrm{Au}$ (major products); Ag (minor product). Ore Materials: Malachite, chrysocolla, gold and specularite. Deposit Description:

Smail, NE trending, $45^{\circ} \mathrm{NW}$ dipping irregular bunches discontinuous pockets. Iregular replacement of hematite and limonite containing small pockets and masses of malachite and chrysocolla, threads and disseminations of gold in quartz.

Geology: Mineralization controlled by fracture intersections in metamorphosed Paleozoic limestone along a steeply dipping thrust fault of Precambrian metamorphics over the sediments.

Production: $\quad$ Some 3000 tons between 1909-1919 and 1943-1960.

References: $\quad$ USGS CRIB Mineral Resources File 12, Record 2817, p. 7191-7193; Keith, 1978.

28. Lion Hill Mine

Other names:

Location:

Glory Group, Rico

$34^{\prime} 10^{\prime} 58^{\prime \prime} \mathrm{W}, 114^{\prime} 11^{\prime} 18^{\prime \prime} \mathrm{W}$, Sec. 25, T1ON, R19W.

Commodities: $\mathrm{Au}$ (major product); $\mathrm{Cu}, \mathrm{Ag}$ (minor products).

Ore materials: Gold, silver, chrysocolla, malachite, limonite and specularite. 
Deposit description:

Smal1, irregular shaped vein/replacement. Workings: underground, including about 2000 feet of drifts, together with some winzes, raises and stopes.

Geology: Mineralization in carboniferous 1 imestone associated with Tertiary intrusive masses and basalt deposits controlled by fracturing and bedding.

Production: Yes, small amount.

References: $\quad$ USGS CRIB Mineral Resources File 12, Record 2818, p. 7194-7196; Keith, 1978.

29. Capiland Mine

Other name:

Location:

Capilano Mine

$34^{0} 11^{\prime} 01^{\prime \prime} \mathrm{N}, 114^{\circ} 12^{\prime} 4^{\prime \prime} \mathrm{W}$, Sec. 26, TION, R19W.

Commodities: $\mathrm{Au}, \mathrm{Cu}$ (major products); $\mathrm{Ag}$ (minor product)

Ore Materials: Chrysocolla, malachite, specularite and gold.

Deposit description:

Smal1, irregular shaped deposit in a yein/shear

zone. Workings: property has been explored by a

shallow shaft and several surface cuts.

Geology: Mineralization in Paleozoic limestone and in

Precambrian schistose quartzite associated with

Tertiary basalt flow.

Production: Limited production.

References: USGS CRIB Mineral Resources File 12, Record 2819, p. 7197-7199; Keith, 1978.

30. Rio Vista Mine

Other names:

Northside, Quartz King

Location:

$34^{0} 10^{\prime} 39^{\prime \prime} \mathrm{N}, 114^{\mathrm{O}} 11^{\prime} 59^{\prime \prime} \mathrm{W}$,

Sec. 26, T1ON, R19W

Commodities: $\mathrm{Cu}, \mathrm{Au}$ (major products); $\mathrm{Ag}$ (minor product).

Ore materials: Chrysocolla, malachite, hematite and specularite.

Deposit description:

Small NS-trending, vertical dipping, irregular, lenticular shaped vein in a shear zone. Workings: underground.

Geology: Mineralization in Paleozoic metamorphosed limestone, and in Precambrian schistose quartzite associated with Tertiary basalt.

Production: 200 tons at $5-8 \% \mathrm{Cu}, 0.4-0.5 \mathrm{oz} \mathrm{Au} / \mathrm{T}$.

References: $\quad$ USGS CRIB Mineral Resources File 12, Record 2820 , p. 7200-7202; Keith, 1978.

31. New Planet Mine

Other names:

Location:

Planet Copper Mine, Planet Mine.

Commodities: $34^{\circ} 14^{\prime} 38^{\prime \prime} \mathrm{N}, 113^{\circ} 58^{\prime} 11^{\prime \prime} \mathrm{W}$

Ore Materials:

Deposit Description:

$\mathrm{Cu}, \mathrm{Au}, \mathrm{Ag}, \mathrm{Fe}$.

Hematite, chrysocolla, gold, silver, bornite, chalcopyrite, pyrite, limonite, azurite and malachite.

Smal1, irregular shaped replacement and veins along

fault zone. Workings: underground. 


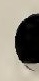


Geology: Mineralization in fault zone. Wall rock brecciated Paleozoic limestone and shale, with gouge, quartz, calcite and feldspar above Precambrian metamorphics.

Production: Worked sporadically from 1863 to $1937,60,000$ tons at $10 \% \mathrm{Cu}$, minor $\mathrm{Au}, \mathrm{Ag}$.

References: $\quad$ USGS CRIB Mineral Resources File 12, Record 2835, p. 7242-7244; Keith, 1978.

\section{Midway Mining Disrict}

Location:

T9N, R16W (south-central Buckskin Mountains).

Comnodities:

$\mathrm{Cu}, \mathrm{Au}, \mathrm{Ag}, \mathrm{Fe}$, marble, $\mathrm{Ba}, \mathrm{F}$.

Ore Materials: Oxidized copper minerals, sulfides, hematite,

Deposit description:

barite, fluorite.

Spotty oxidized, copper mineralization with minor sulfides, usually associated with hematite or with quartz, barite, and fluorite along fracture or fault zones.

Geology: $\quad$ Mineralization in Precambrian schist and Mesozoic

Production: $\quad$ Smaliments or as limestone replacements. since the early 1900 's. Total production would be some 212 tons of ore containing about 4-5 tons of copper, 45 ounces of gold, and 35 ounces of silver. No commercial production of marble has been

Reference: Keith, 1978.

Note: $\quad$ District boundary line is approximate.

\section{Cienega Mining District}

Location:

T9N, R17W, T11N, R19W (west end of Buckskin Mountains).

Commodities: $\mathrm{Cu}, \mathrm{Al}, \mathrm{Ag}, \mathrm{Pb}, \mathrm{Hg}, \mathrm{W}, \mathrm{Ba}$.

Ore materials: Copper silicates, carbonates, oxides, sulfides,

Deposit description: gold.

Smal1, pockety replacement bodies, usually closely associated with faults, fractures and shear zones. Some high grade pockets, and reportedly, cupriferous pyrite and copper sulfides at depth.

Geology: Mineralization associated with faults, fractures and shear zones in thrust faulted blocks of partly metamorphosed Paleozoic and Mesozoic limestones, shales, and quartzites, lying unconformably on Precambrian metamorphics, or in Precambrian metamorphics thrusted over Paleozoic and Mesozoic sediments.

Production: Numerous scattered tunnels, shafts and surface workings, were mined sporadically from the late 1800 's to 1969 . Total estimated and recorded production would be 19,000 tons of ore containing about 917 tons of copper, 11,707 ounces of gold, 3,364 ounces of silver and a few hundred pounds of lead.

Reference: Keith, 1978. 
Note: District boundary line is approximate.

35. Black Metal Copper Mine

Location: $\quad 34^{\circ} 15^{\prime} 22^{\prime \prime} \mathrm{N}, 114^{\circ} 08^{\prime} 53^{\prime \prime} \mathrm{W}$,

Comodities: $\mathrm{Au}, \mathrm{Cu}$.

Ore materials: Not reported.

Deposit description:

Production: Small fissures. Wor

Reference: $\quad$ USGS, 1972, CRIB Mineral Resources File 12, record 2836 , P. $7245-7246$.

\section{Mesa Manganese Prospect.}

Location:

$34^{\circ} 16^{\prime} 54^{\prime \prime} \mathrm{N}, 113^{\circ} 50^{\prime} 44^{\prime \prime} \mathrm{W}$,

Commodity:

Sec. 20, 21, T11N, R15W.

Ore materials: Psilomelane and pyrolusite.

Deposit description:

Smal1, $N 32^{\circ} \mathrm{W}$-trending, $90^{\circ}$ dipping, Dodlike

masses, seams and veinlets in a shear zone and

bedded. Workings: Surface and underground.

Geology: Mineralization in Paleocene limestones, and in

Tertiary sandstones and volcanics associated with Quaternary basalts.

Production: Yes, small amount.

References: USGS, 1979, CRIB Mineral Resources file 12, Record 2394 , P. 2393-2395.

37. Castaneda Group

Location:

$34^{\circ} 22^{\prime} 27^{\prime \prime} \mathrm{N}, 113^{\circ} 52^{\prime} 47^{\prime \prime} \mathrm{W}$,

Sec. 4, T12N, R16W.

Commodity:

$\mathrm{Mn}$

Ore materials: Psilomelane and manganite

Deposit description:

Smal 1, $\mathrm{N} 40^{\circ} \mathrm{W}$-trending, $15^{\circ} \mathrm{NE}$ dipping

deposit, located in bedded and fracture zone.

Geology: Mineralization in Pliocene Artillery Sandstone.

Production: Yes, small amount.

References: USGS, 1979, CRIB Mineral Resources File 12, Record 908, P. 2419-2421.

38. Pilot Rock Mine

Location:

$34^{\circ} 24^{\prime} 35^{\prime \prime} \mathrm{N}, 114^{\circ} 16^{\prime} 30^{\prime \prime} \mathrm{W}$,

Commodity:

Sec. 6, T12N, R19W.

Ore Materials: Psilomelane and pyrolusite.

Deposit Description:

Smal1, N-trending, east dipping enechelon fractures in veins and fracture zones. Workings: surface and underground.

Geology:

Mineralization in Tertiary basalt and sandstones

Production: associated with Precambrian granites.

References:

Yes, small amount.

USGS, 1979 CRIB Mineral Resources file 12, record 
909, p. $2422-2424$.

\section{Arizona Manganese Prospect}

Location: $34^{\circ} 27^{\prime} 14^{\prime \prime} \mathrm{N}, 114^{\circ} 19^{\prime} 46^{\prime \prime} \mathrm{W}$, Sec. 23, T13N, R2OW.

Commodities: $\quad M n$ (major product); Fe (minor product).

Ore materials: Psilomelane and pyrolusite.

Deposit description:

Smail, NW-trending deposits dipping to the NE, located in veins and brecciated zones. Workings: surface.

Geology: Mineralization in Precambrian gneiss, diorite and granite associated with Late Tertiary basalt and sandstone.

Production: Yes, small amount.

References: USGS, 1979, CRIB, Mineral Resources File 12, Record 913, p. 2432-2434.

40. Dutch Flat Mine

Other Name: Kampf.

Location: $\quad 34^{\mathrm{O}} 31^{\mathrm{i}} 55^{\mathrm{\prime}} \mathrm{N}, 114^{\circ} 10^{\prime} 33^{\prime \prime} \mathrm{W}$, Sec. 19, 20, 29 and 30, T14N, R18W.

Commodities: $\quad W, \mathrm{Au}$, (major products); $\mathrm{Ag}, \mathrm{Cu}, \mathrm{Pb}$ (minor products).

Ore Materials: Wolframite, galena and specularite.

Deposit description:

Smail, $N 28^{\circ} \mathrm{W}$-trending, ore body dipping $60 \mathrm{SW}$, stringers, short pods, and lense shaped

Geology: vein. Workings: underground.

associated with granite and basic felsitic dikes.

Production: Yes, small amount.

References: $\quad$ USGS, 1979, CRIB Mineral Resources File 12, Record 916, p. 2440-2442; Wi 1 son, 1941.

41. Chemehuevis Placers
Other name:
Location:
Calizona
Commodity: $\quad \mathrm{Au}$
Ore Material: Gold
Deposit description:
$34^{\circ} 35^{\prime} 01^{\prime \prime N}, 114^{\circ} 17^{\prime} 47^{\prime \prime} \mathrm{W}$,
Small, placer deposits. Workings: Surface.
Production: Yes, small amount.
References: $\quad$ USGS, 1979, CRIB Mineral Resources File 12, Record 917 , p. 2443-2445.
Geology: Conglomerate, fanglomerate and gravels are present.

\section{Yucca Mine}

Location:

Commodity:

$34^{\mathrm{O}} 38^{\prime} 09^{\prime \prime} \mathrm{N}, 114^{\mathrm{O}} 22^{\prime} 28^{\prime} \mathrm{W}$, Sec. $17, T 15 \mathrm{~N}, \mathrm{R} 20 \mathrm{~W}$.

Ore materials: Wad-like oxides, psilomelane and pyrolusite. Deposit description: 
bedded, shear zone. Workings: Surface and underground.

Geology: Mineralization in Tertiary sandstone and andesite flows.

Production: Yes, small amount.

References: USGS, 1979, CRIB Mineral Resources File 12, Record 918 , P. 2446-2448.

\section{Happy Day No. 3 Mine}

Other names: Black Mule, Barite No. 3.

Location: Sec. 31, T7N, R17W.

Commodities: $\mathrm{Ba}, \mathrm{F}$.

Ore Material: Barite and fluorite.

Deposit description:

Irregular lensing barite and fluorite in fault veins

Geology: $\quad$ and breccia zones. Workings: Open cut operations. and breccia zones in rhyolitic volcanics, interbedded with metamorphosed Mesozoic sediments.

Production: $\quad 100$ tons in $1938,80 \% \mathrm{BaSO}_{4}$ and $3.5 \% \mathrm{CaF}_{2}$.

References: $\quad$ McCrory and O'Haire, 1965, Keith, 1978.

84. Chemehuevis District Placers

Other names: Gold Wing District, includes Calizona Placer channel, Fisher Diggings, Silver Creek, the "49",

Chief, and Prentice Gulch properties.

Comodities: $\mathrm{Au}$, rare earths.

Ore Materials: Auriferous gravels, detrital monazite.

Deposit description:

Placer gold deposits.

Geology: $\quad$ Auriferous gravel is in conglomerate or fanglomerate. The source is thought to be gold-bearing quartz veins in Precambrian schist. Placer deposts were worked along the Colorado River, in the Red Hills area and in Dutch and Printer Gulches.

Production: Yes, total between 100 and 1000 troy ounces.

References: Johnson, 1972; Arizona Bureau of Mines, 1969.

85. Santa Maria District Placers

Other names: Planet District Placers

Location: T10N, R15W; T1ON, R16W.

Commodity: $\quad \mathrm{Au}$

Deposit description:

Geology:

Placer. Planet district; presumably they are the source of the gold.

Production: 12 ounces of gold and 12 ounces of silver.

References: Johnson, 1972; Keith, 1978.

95. Golden Ray Mine Group

Location: Sec. 24, T10N, R19W.

Commodities: $\mathrm{Au}, \mathrm{Cu}, \mathrm{Ag}$. 
Ore materials: Copper silicate and carbonate, hematite.

Deposit description:

Spotty copper silicate and carbonate with hematite in irregular replacement bodies in 1 imestone.

Geology:

In folded and faulted Paleozoic limestone along thrust fault zone bringing metamorphosed Precambrian rocks over Paleozoic sediments.

Production: 175 tons in 1940-1941 and 1949-1950.

References: Stipp, Haiger, Alto and Sutherland, 1967; Keith, 1978 .

100. Cienga District Placers

Location: TION, R18W

Deposit description:

Placer.

Production: Some production in 1910.

Reference: Johnson, 1972.

102. Eagle Nest Mine

Location: W central sec. 16, T10N, R18W.

Commodity: $\mathrm{Cu}, \mathrm{Au}, \mathrm{Ag}$.

Ore material: Chrysocolla, malachite, azurite, gold, hematite.

Deposit description:

Spotty and irreguiar lenses and pods of chrysocolla, malachite, and azurite, and hematite with gold values in Paleozoic limestone.

Geology:

Ore bodies closely associated with thrust fault zone and sheared, faulted, fractured and brecciated Paleozoic sediments and thrust faulted overlying

Production: 4000 tons.

References: $\quad$ Stipp et a1., 1967; Keith, 1978.

105. Arizona McGinnis Mine

Other name: Copper Queen

Location:

Cen. sec. 9, NW 1/4 sec. 16, NE 1/4 sec. 17, T10N, R18W.

Commodities: $\mathrm{Cu}, \mathrm{Au}, \mathrm{Ag}$.

Ore Materials: Cuprite, malachite, chrysocolla, gold.

Deposit description:

Spotty cuprite, malachite and chrysocolla in

stringers and replacement. Ore occurs in irregular and shallow shoots with some rich gold pockets.

Geology: Workings: Shaft, tunnel and open cuts. Mineralization in metamorphosed Paleozoic limestone along and below thrust faulted Precambrian quartz schist.
Production: $\quad$ Sporadic workings, 170 tons of ore averaging $9 \% \mathrm{Cu}$, References: Keith, 1978.

109. New Standard Mine

Location:

SW $1 / 4$ sec. 9, T9N, R17W.

Commodities: $\mathrm{Cu}, \mathrm{Fe}, \mathrm{Ag}, \mathrm{Au}$.

Ore Material: Copper carbonate, chalcopyrite, bornite, hematite. 
Deposit description:

Irregular, tabular, replacement bodies, some vein and breccia fillings of hematite cut by stringers and disseminations of copper carbonates. Reported chalcopyrite and bornite at depth.

Geology: Mineralization in Precambrian gneiss and schist and Paleozoic limestone overlying the metamorphic core complex along a probable thrust fault zone.

Production: Worked sporadically from early 1900 's to 1924. Reference: Keith, 1978.

111. Arizona Midway Mine

Location: S. Sec. 1, T8N, R16W.

Commodities: $\mathrm{Cu}, \mathrm{Au}, \mathrm{Ag}$, marble.

Deposit description:

Spotty, oxidized, copper mineralization in

Precambrian schist. Some high grade copper pods.

Limited exposures of varicolored marble bounded by schist.

Geology: Mineralization in Mesozoic schist containing

limestone bands.

Production: Limited production around 1917.

References: Keith, 1978.

120. Battleship Copper Mine

Location: NW 1/4 sec. 3, T8N, R15W.

Commodities: $\mathrm{Cu}, \mathrm{Ag}, \mathrm{Fe}$.

Ore materials: Oxidized copper and sulfides, hematite.

Deposit description:

Spotty oxidized copper mineralization with minor sulfides in irregular, hematite-rich, replacement lenses.

Geology: Mineralization in flat-lying shale beds of metamorphosed Mesozoic sediments, overlying metamorphic core complex.

Production: Limited production in early 1900's.

Reference: Keith, 1978.

\section{Black Chief Mine}

Location: Sec. 24, T7N, R18W.

Commodities: $\mathrm{Mn}$, Fe.

Ore materials: Manganese and iron oxides.

Deposit description:

Irregular, lenticular masses and strands of manganese oxides mixed with iron oxides and calcite in breccia.

Geology: Mineralization in breccia, along a fracture vein in metamorphosed Mesozoic sedimentary rocks.

Production: Small amount of high grade ore during WWII, and some 2000 tons mined in 1953.

Reference: Keith, 1978.

137. Black Mountain Mine Group:

Location: Sec. $34, T 8 N$, R17W.

Commodities: $\mathrm{Ba}, \mathrm{F}, \mathrm{Cu}$. 
Ore Materials: Barite, fluorite, copper staining.

Deposit description:

Fissure veins, voids and replacement. Workings: Open cut and shaft operations.

Geology: Barite with variable fluorite and copper staining, mixed with wall rock in fissure veins, voids, and replacement in strongly fractured Tertiary agglomerate and tuff.

Production: Late 1940 's 2500 tons of $75 \% \mathrm{BaSO}_{4}$ and $14 \%$ $\mathrm{CaF}_{2}$.

References: $\quad$ Stipp et al., 1967, Keith, 1978.

141. Bentonite Mine

Location: Sec. 25, T7N, R17W.

Commodities: Bentonitic clay.

Ore material: Bentonitic clay.

Deposit description:

Bentonitic clay in alluvium. Workings: shallow surface.

Geology: $\quad$ Bentonitic clay in alluvium, probable old lake bed, probable swelling type and derived from alteration of tuffaceous sediments.

Production: Few hundred tons in 1940 's.

References: Stipp et al., 1967; Keith, 1978.

145. Green Streak Mine

Location: NE 1/4 sec. 28, T9N, R16W.

Commodities: $\mathrm{Cu}, \mathrm{Au}, \mathrm{Ag}$.

Ore Material: Oxidized copper mineralization.

Deposit description:

Spotty copper mineralization in a quartz vein.

Geology: Mineralization in quartz vein cutting metamorphic core complex (gneiss and schist).

Production: $\quad 200$ tons of ore in 1953-1954 averaging $1.3 \% \mathrm{Cu}, 0.2$ $0 \mathrm{Z} \mathrm{Au} / \mathrm{T}$ and $0.1 \mathrm{oz} \mathrm{Ag/T}$.

Reference: $\quad$ Keith, 1978.

146. Bullion Mine Group

Other name: Scotchman

Location: SE $1 / 4 \mathrm{sec} .12, T 7 \mathrm{~N}, \mathrm{R} 18 \mathrm{~W}$.

Commoditieso: $\mathrm{Cu}, \mathrm{Au}, \mathrm{Ba}, \mathrm{Fe}, \mathrm{Mn}$.

Ore Materials: Oxidized copper, chalcocite, barite, hematite,

Deposit description: manganese oxide.

Spotty lenses and streaks of leached and oxidized copper mineralization, local chalcocite enrichment. Barite, quartz, calcite, hematite and manganese oxides in gangue.

Geology: Mineralization in fissure veins in metamorphosed Mesozoic schist and limestone cut by diorite porphyry dikes.

Production: $1915-191850$ tons of ore averaging $11 \% \mathrm{Cu}$ and 0.09 $\mathrm{Oz} . \mathrm{Au} / \mathrm{T}$.

Reference: Keith, 1978. 
147. Cindy Mine

Location: W central sec. 19, T7N, R17W.

Commodities: Mn.

Ore materials: Psilomelane and pyrolusite.

Deposit description:

Lenses of psilomelane and pyrolusite mixed with

siliceous limestone and calcite.

Geology: Mineralization in bedding plane fracture in

metamorphosed Mesozoic limestone.

Production: Worked in 1953, producing 144 tons of sorted $25 \% \mathrm{Mn}$.

Reference: Keith, 1978.

148. Coronation Mine Group

Other names: Mystery Hill, Blue Moon, Copper Hill.

Location: Sec. 31, T7N, R17W.

Commodities: $\mathrm{Cu}, \mathrm{Ag}, \mathrm{Au}$.

Ore material: Unknown.

Deposit description:

Spotty copper, silver and gold mineralization, largely oxidized in irregular qauartz veins.

Geology: Mineralization in quartz veins along fractures in Precambrian gneiss.

Production: Worked in late $1940^{\prime}$ 's and early 1950's, producing 115 tons of ore averaging about $1.8 \% \mathrm{Cu}, 0.18 \mathrm{oz}$. $\mathrm{Ag} / \mathrm{T}$ and $0.07 \mathrm{oz}$. Au/T.

Reference: Keith, 1978.

149. Heart's Desire Mine

Other names: Jackson Copper, Copper King.

Location: SE 1/4 sec. 13, T7N, R18W.

Commodities: $\mathrm{Cu}, \mathrm{Pb}, \mathrm{Ag}, \mathrm{Au}$.

Ore Materials: Oxidized copper, lead, silver and gold

Deposit description: mineralization.

Spotty lensing, oxidized copper, lead, silver, and gold mineralization with sulfides at depth, along a fault zone at intersections with cross fractures.

Geology: Mineralization in metamorphosed Mesozoic schist,

$\begin{array}{ll} & \text { with interbedded andesite and cut by diorite dikes } \\ \text { Production: } & \text { Worked from early } 1900^{\prime} \text { s to about } 1914 \text {, producing }\end{array}$ some 200 tons of ore averaging about $7 \% \mathrm{Cu}, 2 \% \mathrm{~Pb}, 3$ $0 \mathrm{z} . \mathrm{Ag} / \mathrm{T}$ and $1.6 \mathrm{Oz} \mathrm{Au} / \mathrm{T}$.

Reference: Keith, 1978.

150. Linda K Mine

Location:

Commodities:

SE $1 / 4 \mathrm{sec} .14, \mathrm{~T} 7 \mathrm{~N}, \mathrm{R} 16 \mathrm{~W}$.

Ore materials: Pyrolusite, psilomelane, and manganite.

Deposit description:

Pyrolusite, psilomelane, and manganite with calcite

Geology: Mineralized fracture zones in Tertiary andesitic and breccia in seams and veinlets in fracture zones.

volcanics covering Tertiary granite.

Production: $\quad 30$ tons in 1918, 1500-2000 tons in 1953-1954.

Reference: $\quad$ Keith, 1978. 
151. Angelus Mine

Location:

SE $1 / 4 \mathrm{sec} .1, \mathrm{~T} 10 \mathrm{~N}, \mathrm{R} 17 \mathrm{~W}$.

Commodities:

Au, $\mathrm{Ag}, \mathrm{Fe}$.

Ore material: Gold, iron oxide.

Deposit description:

Finely divided particles of gold in irregular streaks and small, discontinuous pockets of brecciated to pulverized sugary quartz with abundant

Geology: iron oxide and sericite in a brecciated zone.

schistose quartzite.

Production: $\quad 100$ tons averaging $1 \mathrm{Oz} \mathrm{Au/T}$ and $0.2 \mathrm{oz} . \mathrm{Ag} / \mathrm{T}$. Reference: Keith, 1978.

152. Argus and Maryland Mine Group

Location: $\quad \mathrm{N}$ central sec. 6, T10N, R16W.

Commodities: $\mathrm{Cu}, \mathrm{Fe}, \mathrm{Au}, \mathrm{Ag}$.

Ore material: Cupiferous hematite.

Deposit description:

Irregular lenses of cupiferous hematite in Paleozoic carbonate rocks.

Geology: Mineralized carbonate rocks along or above the brecciated and schistose contact with underlying Precambrian metamorphics.

Production: $\quad 250$ tons of ore averaging $3 \% \mathrm{Cu}, 0.4 \mathrm{oz}$. Au/T, 0.2 Oz. Ag/T.

Reference: $\quad$ Keith, 1978.

153. Lucky Mine Group

Location: S central sec. 12, N central sec. 13, T10N, R17W.

Commodities: $\mathrm{Mn}, \mathrm{Fe}$.

Ore Materials: Manganese and iron oxides.

Deposit Description:

Manganese oxides mixed with iron oxides in irregular replacement lenses in Paleozoic limestone and in fractures, seams, veinlets, and irregular bunches.

Geology: Mineralized limestone beds underlain by sandstone

Production: and Precambrian metamorphics.

Production: 275 tons of ore produced.

Reference: Keith, 1978.

154. Revenue Mine Group

Location: Central sec. 31, T10N, R15W.

Commodities: $\mathrm{Cu}, \mathrm{Fe}, \mathrm{Ag}, \mathrm{Au}$.

Ore material: Oxidized copper mineralization and hematite.

Deposit description:

Oxidized copper mineralization in lensing hematite replacement bodies in folded and faulted Paleozoic limestone.

Geology: $\quad$ Mineralized faulted Paleozoic limestone along a fault contact with underlying Precambrian metamorphic rocks. Granite nearby.

Production: $\quad 200$ tons averaging $2 \% \mathrm{Cu}$ and minor gold. 
Reference: $\quad$ Keith, 1978.

157. Lake Havasu Sand and Gravel

Location: $\quad T 13 \mathrm{~N}$, R20W.

Commodities: Sand and gravel.

Production: $\quad 1,553,000$ tons as of 1967 .

Reference: Arizona Bureau of Mines, 1969.

159. Plomosa Mining District

Location: T8N, R18W

Commodities: $\mathrm{Au}, \mathrm{Ag}, \mathrm{Cu}, \mathrm{Pb}, \mathrm{Zn}, \mathrm{Mn}, \mathrm{Ba}, \mathrm{Fe}$, bentonite.

Ore materials: Gold, partly oxidized copper minerals, lead and zinc minerals, iron and manganese oxides, barite, fluorite.

Deposit description:

Spotty, partly oxidized copper and gold

mineralization with minor lead and zinc, with

quartz, iron and manganese oxides in irregular fault and fracture veins, in metamorphosed Mesozoic sediments, shale, sandstone, conglomerate, and 1 imestone; Precambrian metamorphics; and Cretaceous or Tertiary volcanics, with diorite and granite intrusions. Manganese oxides occur also in irregular lenticular bodies and veinlets with variable amounts of iron oxides, calcite, barite and gypsum. Fracture and breccia zones in Cretaceous or Tertiary andesitic volcanics. Barite and fluorite also occur in veins along faults and fractures in Cretaceous or Tertiary volcanic flows and agglomerates. Copper, lead and zinc mineralization occurs with silver and gold, associated iron and manganese, in faulted Palenzoic limestone blocks and irregular veins in Cretaceous or Tertiary andesite volcanics, cut by quartz monzonite intrusives. Gold and silver mineralization in irregular veins along fractures and fault zones associated with quartz stringers and Laramide diorite and granite porphyry dikes in Mesozoic schist. Bentonitic clay occurs in probable lake bed sediment.

Production: 26,000 tons of ore produced in the district (which includes areas outside of the Bill Williams GRA). The ore contained about 26,000 tons of copper, 344 tons of lead, 65 tons of zinc, 7,000 ounces of gold, and 127,400 ounces of silver. Some 9000 tons of manganese ore, 2700 tons of barite ore, and a small amount of bentonite production.

Reference: Keith, 1978.

Note: $\quad$ District boundary line is approximate.

\section{Santa Maria Mining District}

Location: T9N, R15W, T11N, R17W.

Commodities: $\mathrm{Cu}, \mathrm{Fe}, \mathrm{Mn}, \mathrm{Au}, \mathrm{Ag}$.

Ore materials: Copper oxides and sulfides, hematite, manganese

Deposit description: oxides, gold. 

Oxide and sulfide copper mineralization in irregular, lensing and often massive iron oxide replacement bodies in bedded, faulted, folded and tilted Paleozoic limestone, marble, and dolomite and in Precambrian schist, usually close to faulted and brecciated contact of carbonate beds with Precambrian gneiss and schist. Manganese oxides associated with iron oxides occur in irregular bodies along shear zones in Paleozoic quartzite and limestone and along Paleozoic limestone beds. Free gold occurs in fractures in Paleozoic or Precambrian quartzite.

Production: Several large scale open pit and shaft operations and many smaller mines and prospects worked from the $1860^{\prime} \mathrm{s}$ to recent times. Total estimated and recorded mine production of base and precious metals is some 1.4 million tons of ore containing 23 thousand tons of copper, 1008 ounces of gold, 35 thousand ounces of silver, 400 tons of manganese ore and concentrates have been shipped.

Reference: Keith, 1978.

Note:

District boundary line is approximate.

\section{Known Prospects, Mineralized Areas, And Geothermal Resources with No Recorded Production}

\section{Buckskin Mountain-Mineral Hill}

Location:

$34^{0} 14^{\prime} 20^{\prime \prime} \mathrm{N}, 113^{0} 59^{\prime} 30^{\prime \prime} \mathrm{W}$

NW $1 / 4$ sec. 1, T10N, R17W. Location was modified from the CRIB location by use of the geologic descriptions in Arizona Bureau of Mines Bulletin 180 .

Commodities: $\mathrm{Fe}, \mathrm{Sb}, \mathrm{Cu}$.

Ore Materials: Hematite, copper minerals.

Deposit description and geology:

Specularite and associated copper minerals replace beds of metamorphosed Paleozoic limestone.

Production: Unknown.

References: $\quad$ USGS CRIB Mineral Resources File 12, Record 2657, p. 6758; Arizona Bureau of Mines Bulletin 180.

5. Good Bet Prospect

Other name: Smokey.

Location:

$33^{0} 56^{\prime} 11^{\prime \prime} \mathrm{N}, 113^{\circ} 55^{\prime} 29^{\prime \prime} \mathrm{W}$,

Commodity: Fe.

Ore Material: Hematite.

Deposit Description:

Small replacement deposit.

Geology:

Ore is in fractured Mesozoic granite and replaces

Production: limestone.

Reference:

None.

USGS, CRIB Minera! Resources File 12, Record 2775 , p. 7076-7077. 
10. Bouse Gold-Copper Prospect

Location:

$33^{0} 56^{\prime} 04^{\prime \prime} \mathrm{N}, 114^{\circ} \mathrm{n} 4^{\prime} 43^{\prime \prime} \mathrm{W}$,

Commodities: $\mathrm{Au}, \mathrm{Cu}, \mathrm{Fe}$.

Ore materials: Hematite.

Deposit description:

300 feet long, 30 to 40 feet thick, irregularly shaped replacement deposit. Workings: inclined shaft.

Geology: Hematite replaces Precambrian(?) limestone which has been intruded by Precambrian(?) biotite granite.

Production: Unknown.

Reference: $\quad$ USGS CRIB Mineral Resources File 12, Record 2780, p. 7090-7091.

16. Mineral No. 1 Prospect

Location: $\quad 34^{8} 08^{\prime} 45^{\prime \prime} \mathrm{N}, 114^{\circ} 04^{\prime} 42^{\prime \prime} \mathrm{W}$,

Sec. 6, T9N, R17W.

Commodity: Au.

Ore material: Gold.

Deposit description:

Smail $550^{\circ} E$-trending, NE dipping, irregularly shaped vein. Workings consist of shallow shaft and surface cut.

Geology: Mineralization in Precambrian gneiss and schist associated with Tertiary aplite, pegmatite and basic dikes. Gangue is quartz.

Production: None.

Reference: USGS CRIB Mineral Resources File 12, Record 2800, p. 7147-7149.

17. Mail Pouch Prospect

Other name: Liftle Golden

Location:

$34^{\circ} 08^{\prime} 08^{\prime \prime} \mathrm{N}, 114^{\circ} 03^{\prime} 15^{\prime \prime}$,

Commodity:

Sec. 9, T9N, R17W.

Ore material: Gold.

Deposit description:

Small $\mathrm{S} 20^{\circ} \mathrm{E}$-trending, $40^{\circ} \mathrm{N}$ dip, irregularly shaped vein, workings consist of a short shaft and open cuts.

Geology: Mineralization in metamorphic core complex (gneiss-schist), associated with Tertiary aplite, pegmatite and basic dikes.

Production: None:

References: USGS CRIB Mineral Resources File 12, Record 2801, p. 7150-7151.

\section{Mohave Chief and Norma Prospect}

Location:

$34^{\circ} 13^{\prime} 48^{\prime \prime} \mathrm{N}, 114^{\circ} 00^{\prime} 37^{\prime \prime} \mathrm{W}$,

Commodity:

Sec. 10, 11, T10N, R17W.

Ore materials: Chrysocolla and brochantite.

Deposit description: 
Smal $1 \mathrm{~N} 20^{\circ} \mathrm{W}$-trending, irregular shaped

replacement, surface and underground workings

consist of several open cuts and an adit.

Geology: Mineralization in Paleozoic limestone, shale and

quartz chlorite schist.

Production: None.

References: $\quad$ USGS CRIB Mineral Resources File 12, Record 2812, p. 7177-7178.

32. Dome City Prospect

Location: $\quad 34^{\circ} 09^{\prime} 39^{\prime \prime} \mathrm{N}, 114^{\circ} 04^{\prime} 44^{\prime \prime} \mathrm{W}$,

Sec. 31, T1ON, R17W, and sec. 36, T10N, R18W.

Commodities: $\mathrm{Au}$ (major product); $\mathrm{Fe}$ (minor product).

Ore material: Specularite.

Deposit description:

Small, irregular shaped vein, surface and

underground workings which consist of shallow shafts and open cuts.

Geology: Mineralization in Precambrian gneiss and schist

associated with Tertiary aplite, pegmatite and basic dike.

Production: None.

References: $\quad$ USGS CRIB Mineral Resources File 12, Record 2822, p. 7206-7208.

43. Unnamed Fluorspar Occurrence

Location: Sec. 21, T10N, R17W.

Commodity: $\quad F$

Production: Unknown.

Reference: McCrory and O'Haire, 1965.

44. Unnamed Sand, Gravel and Crushed Rock Occurrence

Location: Sec. 36, T10N, R19W.

Commodities: Sand, gravel and crushed rock.

Production: Unknown

Reference: $\quad$ McCrory and 0'Haire, 1965.

45. Unnaned Sand, Gravel and Crushed Rock Occurrence

Location: $\quad$ Sec. 26, T10N, R19W.1

Commodities: Sand, gravel and crushed rock.

Production: Unknown.

Reference: McCrory and O'Haire, 1965.

46. Unnamed Sand, Gravel and Crushed Rock Occurrence

Location:

Sec. 1, T9N, R19W.

Commodities: Sand, gravel and crushed rock.

Production: Unknown.

References: $\quad$ McCrory and O'Haire, 1965.

47. Unnamed Barite Occurrence

Location: $\quad$ Sec. 17, T7N, R17W.

Commodity: $\quad \mathrm{Ba}$.

Production: Unknown.

References: $\quad$ McCrory and O'Haire, 1965. 
48. Unnamed Barite Occurrence

Location: $\quad$ Sec. 20, T7N, R17W.

Commodity: Ba.

Production: Unknown.

Reference: $\quad$ McCrory and O'Haire, 1965.

49. Unnamed Barite Occurrence

Location: Sec. 35, T8N, R17W.

Commodity: Ba.

Production: Unknown.

Reference: $\quad$ McCrory and O'Haire, 1965.

50. Unnamed Barite Occurrence
Location:
Comodity:
Sec. 12, T7N, R17W.
Production:
Ba.
Reference:
Unknown.
McCrory and O'Haire, 1965.

51. Unnamed Barite Occurrence
Location:
Commodity:
Sec. 7, T7N, R16'.
Production:
Ba.
References:
Unknown.
McCrory and O'Haire, 1965.

53. Unnamed Barite Occurrence
Location:
Sec. 31, T7N, R17W.
Cormodity:
Ba.
Production:
Unknown.
References: McCrory and O'Haire, 1965.

54. Unnamed Barite Occurrence
Location:
Commodity:
Sec, 32, T7N, R17W.
Production:
$\mathrm{Ba}$
References:
Unknown.
McCrory and O'Haire, 1965.

55. Unnamed Mineral Occurrence

Location: Sec. 30, T16N, R20W.

Commodity: Unknown.

Production: Unknown.

Reference: Stipp et al., 1967.

56. Unnamed Mineral Occurrence

Location: Sec. 34, T16N, R20W.

Commodity: Unknown.

Production: Unknown.

Reference: $\quad$ Stipp et al., 1967.

57. Unnamed Mineral Occurrence

Location: Sec. 30, T16N, R18W.

Commodity: Unknown.

Production: Unknown.

References: $\quad$ Stipp et al., 1967.

58. Unnamed Mineral Occurrence 

Location: Sec. 5, 6, T15N, R20W.

Commodity: Unknown.

Production: Unknown.

References: Stipp et al., 1967.

59. Unnamed Mineral Occurrence

Location: Sec. 4, 5, T15N, R20W.

Commodity: Unknown.

Production: Unknown.

References: $\quad$ Stipp et a1., 1967.

60. Unnamed Mineral Occurrence
Location:
Commodity:
Sec. 33, 34, T15N, R20W.
Production:
Unknown.
Reference:
Unknown.
Stipp et al., 1967.

61. Osborne Wash Uraniun Occurrence

Location: W $1 / 2 \mathrm{sec} .4$, T9N, R17W.

Commodity: $U$.

Ore materials: No uranium mineralization reported.

Deposit Description:

$3 \times$ background radiation in limonite altered crystalline rocks.

Geology: $\quad$ Recrystallized Tertiary limestone barren of mineralization, is in low angle fault contact with gneissic rocks. Radiation is associated with $\mathrm{Cu}$ -

Production: $\mathrm{Fe}-\mathrm{Mn}($ ?) mineralization.

Reference:

Unk nown.

Scarborough and wilt, 1979.

62. Unnamed Manganese Occurrence

Location: Sec. 30, T15N, R20W.

Commodity: $\quad \mathrm{Mn}$.

Production: Unknown.

Reference: $\quad$ Stipp et a1., 1967.

63. Unnaned Silver and Gold Occurrence

Location: Sec. 4, T15N, R18W.

Commodities: $\mathrm{Ag}, \mathrm{Au}$.

Production: Unknown.

Reference: Stipp et a7., 1967.

64. Unnamed Mineral Occurrence

Location: $\quad$ Sec. 9, T15N, R18W.

Commodity: Unknown.

Production: Unknown.

Reference: $\quad$ Stipp et al., 1967.

65. Unnamed Gold Occurrence

Location:

Commodity:

Production:

Reference:
Sec. 23, T14N, R20W.

Au.

Unknown.

Stipp et al., 1967. 

66. Unnamed Copper Occurrence
Location:
Commodity:
Sec. 36, T14N, R2OW.
Production:
Cu.
Reference:
Unknown.
Stipp et al., 1967.

67. Unnamed Gold Occurrence
Location:
Commodity:
Production:
Sec. 6, T14N, R19W.
$\mathrm{Au}$.
Reference:
Unknown.
Stipp et al., 1967.

68. Unnamed Mineral Occurrence
Location:
Sec. 17, T14N, R19W.
Commodity:
Unknown.
Production:
Unknown.
Reference:
Stipp et a1., 1967.

69. Unnamed Mineral Occurrence
Location:
Commodity:
Sec. 16, T14N, R19W.
Production:
Unknown.
Reference:
Unknown.
Stipp et al., 1967.

70-75. Unnamed Gold and Tungsten Occurrences Location: 70: Sec. 25, T14N, R19W, 71: Sec. 16, T14N, R18W, 72: Sec. 19, T14N, R18W, 73: Sec. 21, T14N, R18W, 74: Sec. 29, 30, T14N, R18W, 75: Sec. 31, T14N, R18W.

Commodities: $\mathrm{Au}, \mathrm{W}$.

Production: Unknown.

Reference: Stipp et al., 1967.

76. Unnamed Manganese Occurrence

Location: Sec. 7, T13N, R19W.

Commodity: $\quad \mathrm{Mn}$.

Production: Unknown.

Reference: $\quad$ Stipp et al., 1967.

77. Unnamed Mineral Occurrence

Location: Sec. 8, T13N, R18W

Commodity: Unknown.

Production: Unknown.

Reference: $\quad$ Stipp et al., 1967.

78. Unnamed Manganese Occurrence
Location:
Commodity:
Sec. 9, T12N, R19W.
Production:
$\mathrm{Mn}$.
Reference:
Unknown.
Stipp et al., 1967.

79. Unnamed Manganese Occurrence

Location:

Sec. 8, T12N, R17W. 

Comodity: $\quad M n$.

Production: Unknown.

Reference: Stipp et al., 1967.

80. Unnamed Manganese Occurrence

Location: Sec. 13, T12N, R17W.

Commodity: $\quad \mathrm{Mn}$.

Production: Unknown.

Reference: $\quad$ Stipp et a1., 1967.

81. Unnamed Mineral Occurrence

Location: Sec. 20, T12N, R17W.

Commodity: Unknown.

Production: Unknown.

Reference: $\quad$ Stipp et a1., 1967.

82. Unnamed Manganese Occurrence

Location: Sec. 26, T12N, R16W.

Commodity: $\quad \mathrm{Mn}$.

Production: Unknown.

Reference: Stipp et a1., 1967.

83. Unnamed Gold Occurrence

Location: Sec. 24, T12N, R15W.

Commodity: Au.

Production: Unknown.

Reference: $\quad$ Stipp et al., 1967.

86. Unnamed Manganese Occurrence

Location: $\quad$ Sec. 34, T11N, R18W.

Commodity: $\quad \mathrm{Mn}$.

Production: Unknown.

Reference: $\quad$ Stipp et a1., 1967.

87. Unnamed Manganese Occurrence

Location: $\quad$ Sec. 18, T11N, R16W.

Commodity: $\quad \mathrm{Mn}$.

Production: Unknown.

Reference: $\quad$ Stipp et a1., 1967.

88. Unnamed Manganese Occurrence

Location: $\quad$ Sec. 20, T11N, R15W.

Commodity: $\mathrm{Mn}$.

Production: Unknown.

Reference: Stipp et al., 1967.

89. Unnamed Silver Occurrence

Location: $\quad$ Sec. 17, T11N, R15W.

Commodity: $\quad \mathrm{Ag}$.

Production: Unknown.

Reference: Stipp et al., 1967.

90. Unnamed Copper Occurrence

Location: Sec. 31, T11N, R16W.

Commodity: $\mathrm{Cu}$. 
Production: Unknown.

Reference: Stipp et al., 1967.

91. Unnamed Iron Occurrence
Location:
Commodity:
Sec. 31, T11N, R16W.
Production:
$\mathrm{Fe}$.
Reference:
Unknown.
Stipp et a1., 1967.

92. Unnamed Manganese Occurrence

Location: Sec. 26, T10N, R19W.

Commodity: $\quad \mathrm{Mn}$.

Production: Unknown.

Reference: $\quad$ Stipp et a1., 1967.

93. Unnamed Copper Occurrence
Location:
Commodity:
Production:
Sec. 35, T10N, R19W.
Reference:
$\mathrm{Cu}$.
Unknown.
Stipp et al., 1967.

94. Unnamed Copper and Gold Occurrence

Location: Sec. 23, T10N, R19W.

Commodities: $\mathrm{Cu}, \mathrm{Au}$.

Production: Unknown.

Reference: $\quad$ Stipp et al., 1967.

96. Unnamed Copper and Gold Occurrence

Location: Sec. 27, T10N, R19W.

Commodities: $\mathrm{Cu}, \mathrm{Au}$.

Production: Unknown.

Reference: Stipp et al., 1967.

97. Unnamed Mineral Occurrence

Location: Sec. 9, T10N, R18W.

Commodity: Unknown.

Production: Unknown.

Reference: $\quad$ Stipp et a1., 1967.

98. Unnamed Mineral Occurrence

Location: Sec. 17, T10N, R18W.

Commodity: Unknown.

Production: Unknown.

Reference: Stipp et al., 1967.

99. Unnamed Mineral Occurrence

Location: Sec. 19, 20, 29 and 30, T10N, R18W.

Commodity: Unknown.

Production: Unknown.

Reference: Stipp et al., 1967.

101. Unnamed Molybdenum Occurrence

Location: Sec. 18, T10N, R18W.

Commodity: Mo.

Production: Unknown. 
Reference: Stipp et a1., 1967.

103-104. Unnamed Silver, Copper and Gold Occurrences

Location: 103: Sec. 21, T10N, R18W,

104: Sec. 30, T10N, R18W.

Commodities: $\mathrm{Ag}, \mathrm{Cu}, \mathrm{Au}$.

Production: Unknown.

References: Stipp et al., 1967.

106. Unnamed Iron Occurrence

Location: Sec. 34, T10N, R18W.

Commodity: Fe.

Production: Unknown.

Reference: $\quad$ Stipp et al., 1967.

107. Unnamed Mineral Occurrence

Location: Sec. 7, T1ON, R17W.

Commodity: Unknown.

Production: Unknown.

Reference: $\quad$ Stipp et al., 1967.

108. Unnamed Copper and Gold

Location: Sec. 9, T10N, R17W.

Commodities: $\mathrm{Cu}, \mathrm{Au}$.

Production: Unknown.

Reference: Stipp et al., 1967.

110. Unnamed Iron Occurrence

Location: Sec. 3, T10N, R17W.

Commodity: Fe.

Production: Unknown.

Reference: Stipp et al., 1967.

112. Unnamed Manganese Occurrence

Location: Sec. 23, T10N, R17W.

Commodity: Mn.

Production: Unknown.

Reference: Stipp et al., 1967.

113. Unnamed Iron Occurrence

Location: Sec. 7, T10N, R16W.

Commodity: Fe.

Production: Unknown.

Reference: Stipp et al., 1967.

114. Unnamed Copper Occurrence

Location: Sec. 7, 8, T10N, R16W.

Commodity: Cu.

Production: Unknown.

Reference: Stipp et al., 1967.

115. Unnamed Copper and Gold Occurrence

Location:

Commodities:

Production:

Sec. 31, T10N, R16W.

$\mathrm{Cu}, \mathrm{Au}$.

Unknown. 

Reference: $\quad$ Stipp et a1., 1967.

116. Unnamed Iron Occurrence

Location: Sec. 29, T10N, R16W.

Commodity: Fe.

Production: Unknown.

Reference: $\quad$ Stipp et a1., 1967.

117. Unnamed Fluorite Occurrence

Location: Sec. 29, T10N, R16W.

Commodity: $\quad F$.

Production: Unknown.

Reference: $\quad$ Stipp et a1., 1967.

118. Unnamed Mineral Occurrence

Location: Sec. 4, T9N, R18W.

Commodity: Unknown.

Production: Unknown.

Reference: $\quad$ Stipp et al., 1967.

119. Unnamed Copper Occurrence
Location:
Commodity:
Sec. 4, T9N, R17W.
Production:
$\mathrm{Cu}$.
Reference:
Unknown.
Stipp et al., 1967.

121. Unnamed Copper and Gold Occurrence

Location: Sec. 10, T9N, R17W.

Commodities: $\mathrm{Cu}, \mathrm{Au}$.

Production: Unknown.

Reference: $\quad$ Stipp et al., 1967.

122. Unnamed Manganese Occurrence
Location:
Commodity:
Sec. 7, T9N, R16W.
Production:
Mn.
Reference: $\quad$ Stipp et al., 1967.

123.

Unnamed Copper and Gold Occurrence

Location: Sec. 4, T9N, R15W.

Commodity: $\mathrm{Cu}, \mathrm{Au}$.

Production: Unknown.

Reference: $\quad$ Stipp et a1., 1967.

124. Unnamed Copper and Gold Occurrence

Location: Sec. 31, T9N, R14W.

Commodities: $\mathrm{Cu}, \mathrm{Au}$.

Production: Unknown.

Reference: $\quad$ Stipp et a1., 1967.

125-131. Unnamed Manganese Occurrences

Location: 125: Sec. 14, T7N, R17W,

126: Sec. 18, T7N, R17W,

127: Sec. 20, T7N, R17W,

128: Sec. 29, T7N, R17W, 


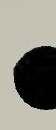

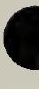


129: Sec. $33, T 7 N, R 17 W$,

130: Sec. $25,36, T 7 N, R 17 W$,

131: Sec. 22, T7N, R16W.

Commodity: $\quad M n$.

Production: Unknown.

Reference: $\quad$ Stipp et a1., 1967.

132. Unnamed Copper, Silver and Gold Occurrence

Location: $\quad$ Sec. 5, T7N, R17W.

Cormodities: $\mathrm{Cu}, \mathrm{Ag}, \mathrm{Au}$.

Production: Unknown.

Reference: $\quad$ Stipp et al., 1967.

133. Unnamed Copper and Gold Occurrence

Location: $\quad$ Sec. 17, T7N, R17W.

Commodities: $\mathrm{Cu}, \mathrm{Au}$.

Production: Unknown.

Reference: Stipp et al., 1967.

134. Unnamed Copper, Gold and Lead Occurrence

Location: Sec. 19, T7N, R17W.

Commodities: $\mathrm{Cu}, \mathrm{Au}, \mathrm{Pb}$.

Production: Unknown.

Reference: Stipp et al., 1967.

135. Unnamed Gold Occurrence

Location: $\quad$ Sec. 30, T7N, R17W.

Commodity: $\quad \mathrm{Au}$.

Production: Unknown.

Reference: $\quad$ Stipp et a1., 1967.

138-140. Unnamed Barite Dccurrences

Location: $\quad 138$ : Sec. 1, 12, T7N, R17W,

139: Sec. $16,21, T 7 N, R 17 W$,

Commodity: $\quad \mathrm{Ba}$.

Production: Unknown.

Reference: Stipp et a1., 1967.

142. Unnamed Bentonite Occurrence

Location: $\quad$ Sec. 35, T7N, R17W.

Commodity: be

Production: Unknown.

Reference: $\quad$ Stipp et a1., 1967.

143. Unnamed Copper and Gold Occurrence

Location: $\quad$ Sec. 25, T7N, R17W.

Commodity: $\quad \mathrm{Cu}, \mathrm{Au}$.

Production: Unknown.

Reference: Stipp et al., 1967.

144. Squaw T Claims

Location: T7N, R15W.

Commodities: $\mathrm{Cu}, \mathrm{W}, \mathrm{Be}$.

Ore materials: Copper and tungsten minerals. 
Deposit description:

Copper and tungsten minerals in contact

metamorphosed schist. Grade $0.03 \% \mathrm{Be} 0$.

References: Arizona Bureau of Mines, 1969; Stipp et al., 1967.

155. Unnamed Marble Occurrence

Location: T9N, R16W.

Commodity: Marble.

Deposit Description:

Coarsely crystall ine, marmorized Paleozoic

1 imestone.

Production: None.

Reference: Arizona Bureau of Mines, 1969.

156. Unnamed Pumicite Occurrence

Location: T7N, R17W.

Commodities: Pumicite.

Ore material: Pumicite bef.

Production: None.

Reference: Arizona Bureau of Mines, 1969.

158. Geothermal Well Site MH-19

Location: Center sec. 20, T11N, R16W.

Temperature: $\quad 54^{\circ} \mathrm{C}$.

Well depth: 625 metgrs.

Heat flow: $\quad 70 \mathrm{~mW} / \mathrm{m}^{2}$.

Production: None.

Reference: Witcher et al., 1982.

161. Unnamed Uranium Occurrence

Location: SE $1 / 4$ of SE $1 / 4 \mathrm{sec}$ 18, T11N, R17W

Commodity: U.

Deposit Description:

Production: None.

\section{Mining Claims, Leases, and Material Sites}

The most important details pertaining to the mining claims density (number of claims per square mile) in the Bill Williams GRA and other relevant records are summarized in table 2 and are shown in figures 7 and 8 . Additionally, in the figures, locations and number of potential claims are also shown. All data have been obtained from and are reported after the BLM's records as of June, 1982. It is easy to note that the distribution of claims and their density within the Bill Williams GRA is very irregular and grouped in certain areas (figs. 7 and 8 ). 


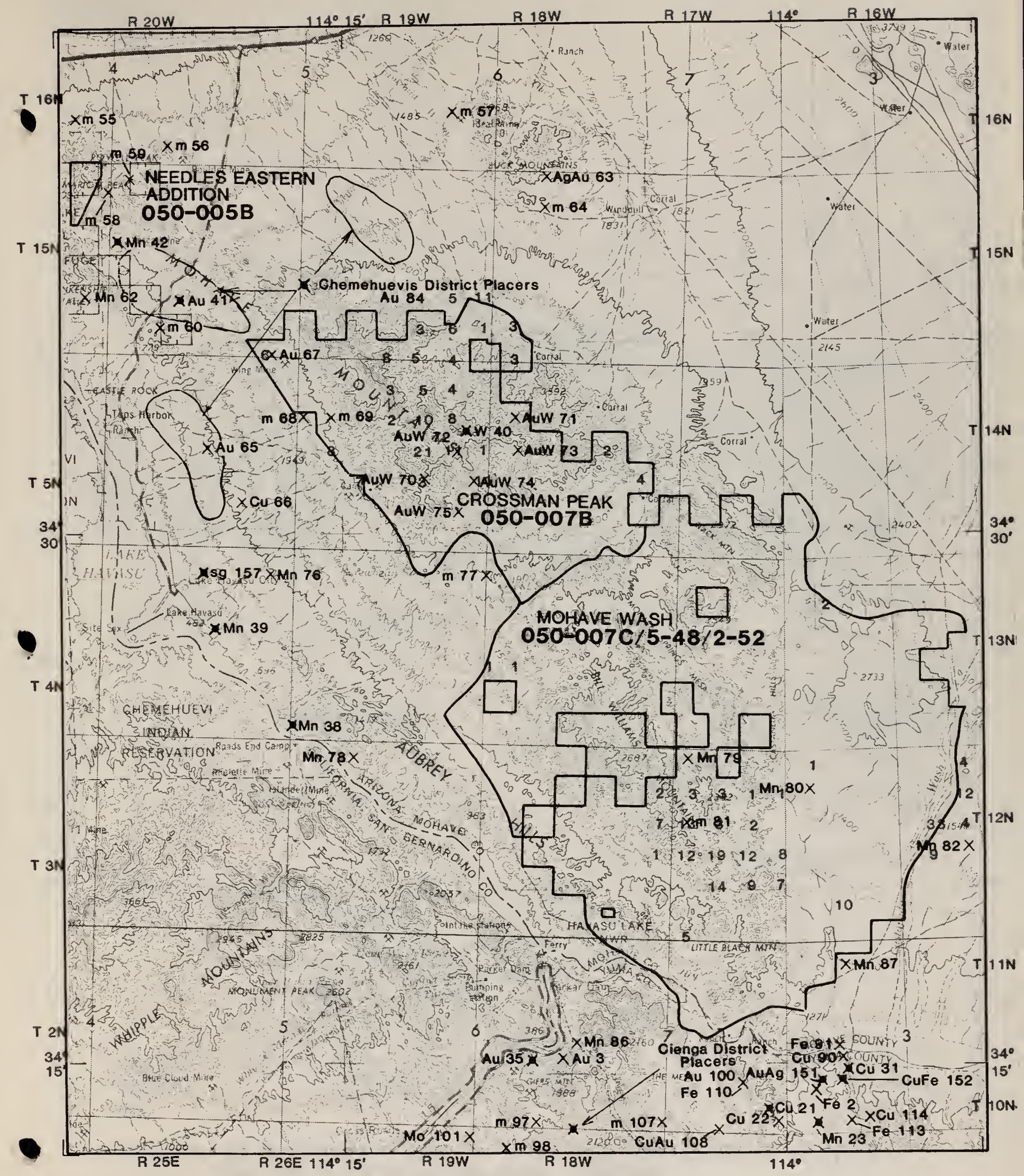

Figure 7 CLAIM DENSITY MAP, WITH OIL AND GAS LEASING STATUS, OF THE HAVASU SUB-AREA, ARIZONA.

Note: hachured lines enclose oil and gas leases; numbers are claims per section. 
TABLE 2

CLAIM DENSITY RECORDS IN THE WILDERNESS STUDY AREAS (WSA), BILL WILLIAMS GRA ACCORDING TO BLM (JUNE 1982), ARIZONA STATE OFFICE

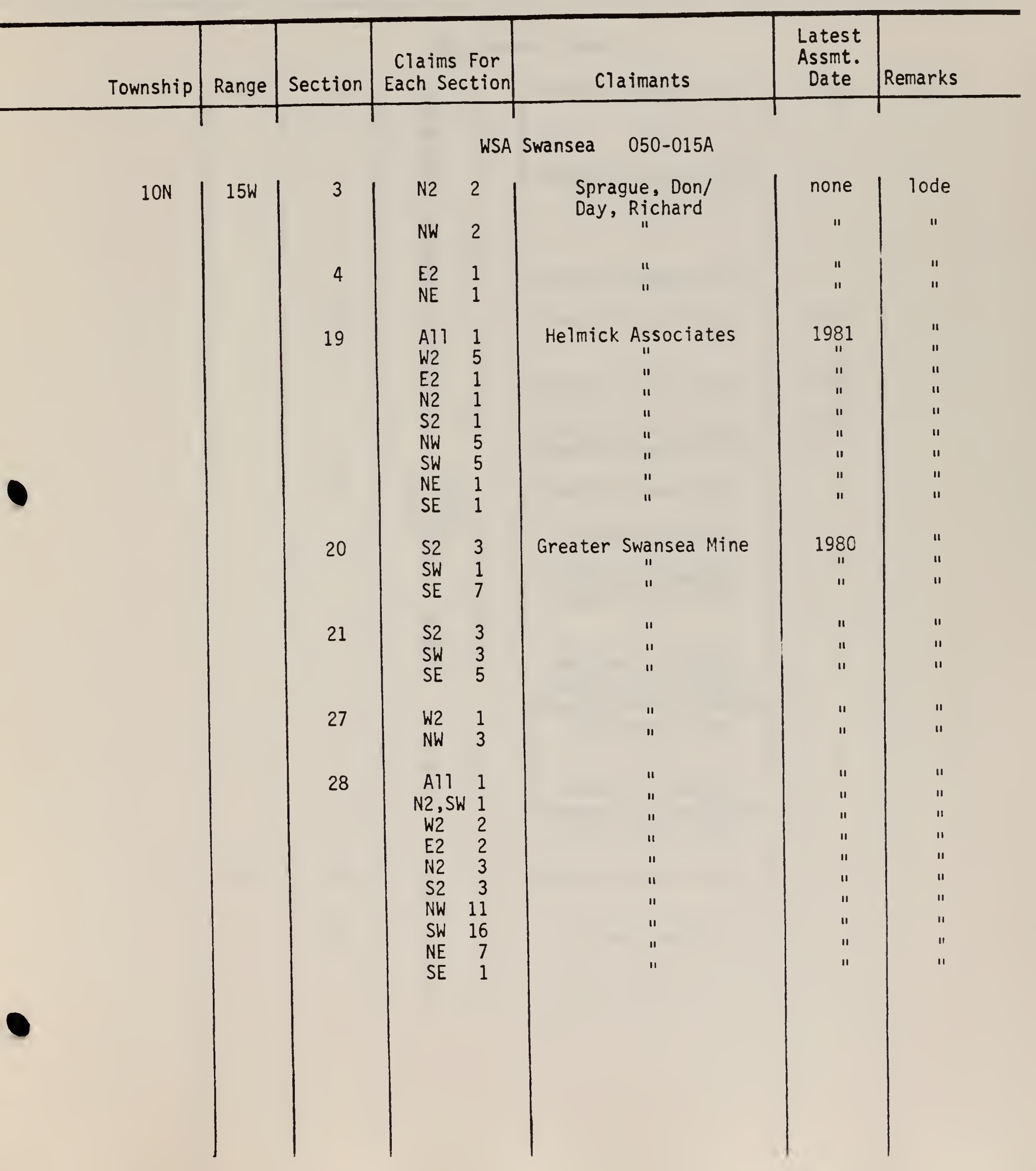


TABLE (Cont'd.)

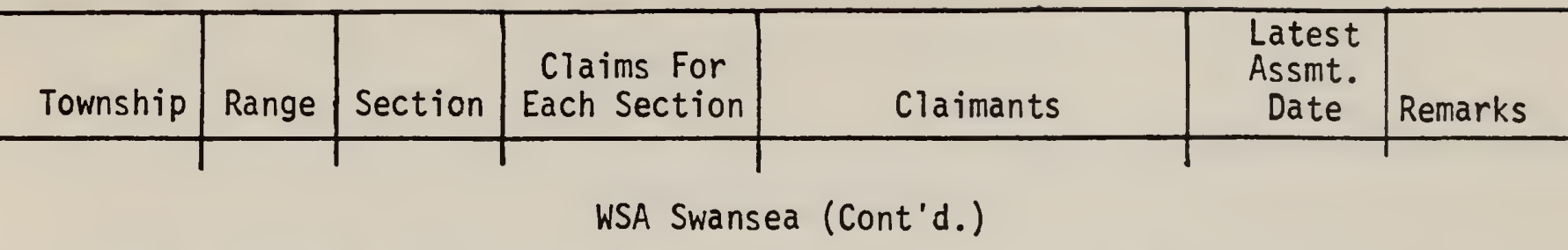

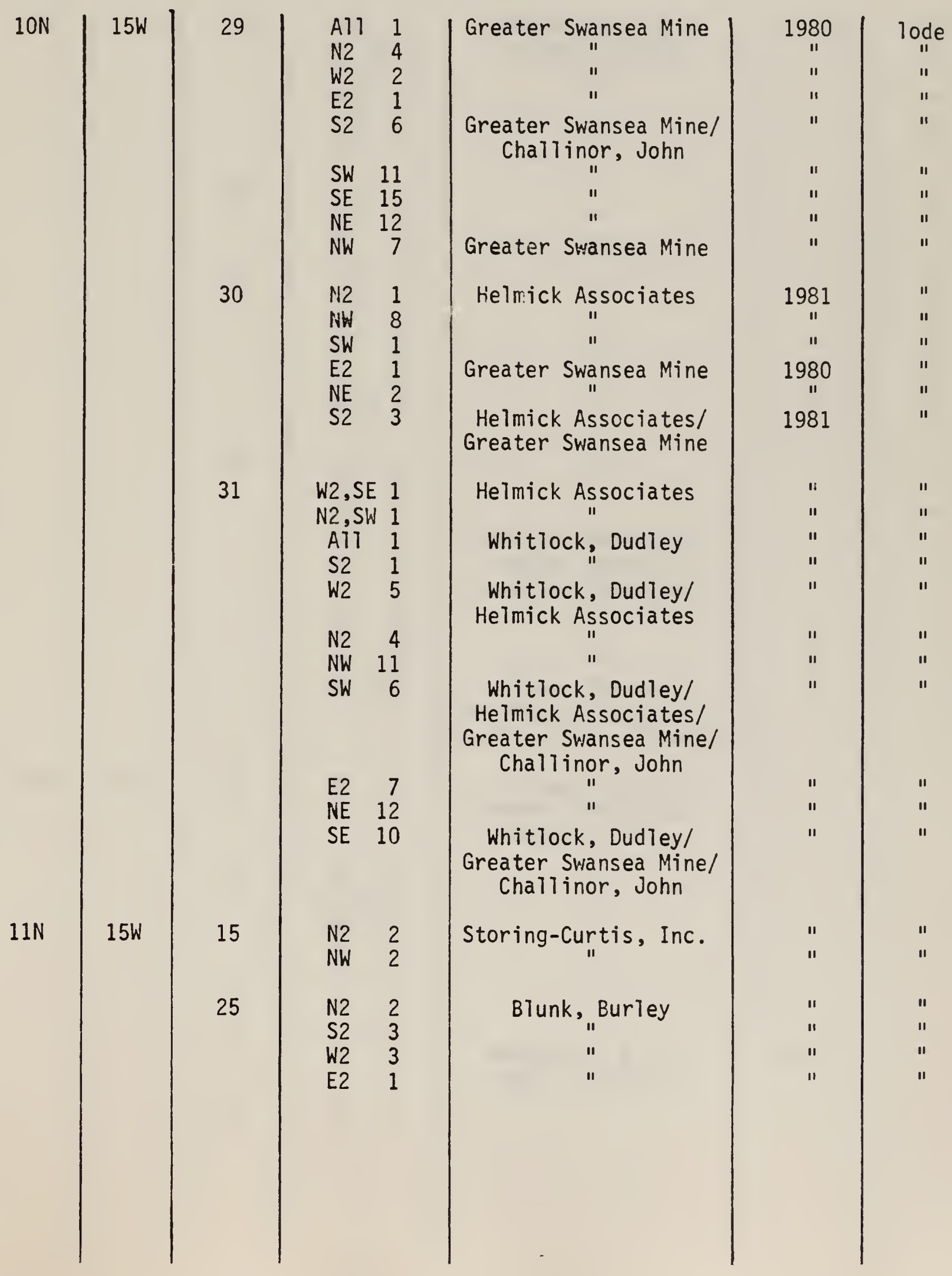


TABLE (Cont'd.)

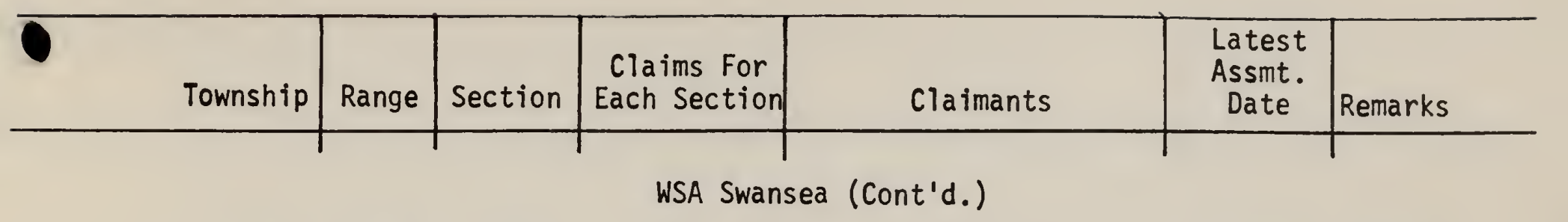

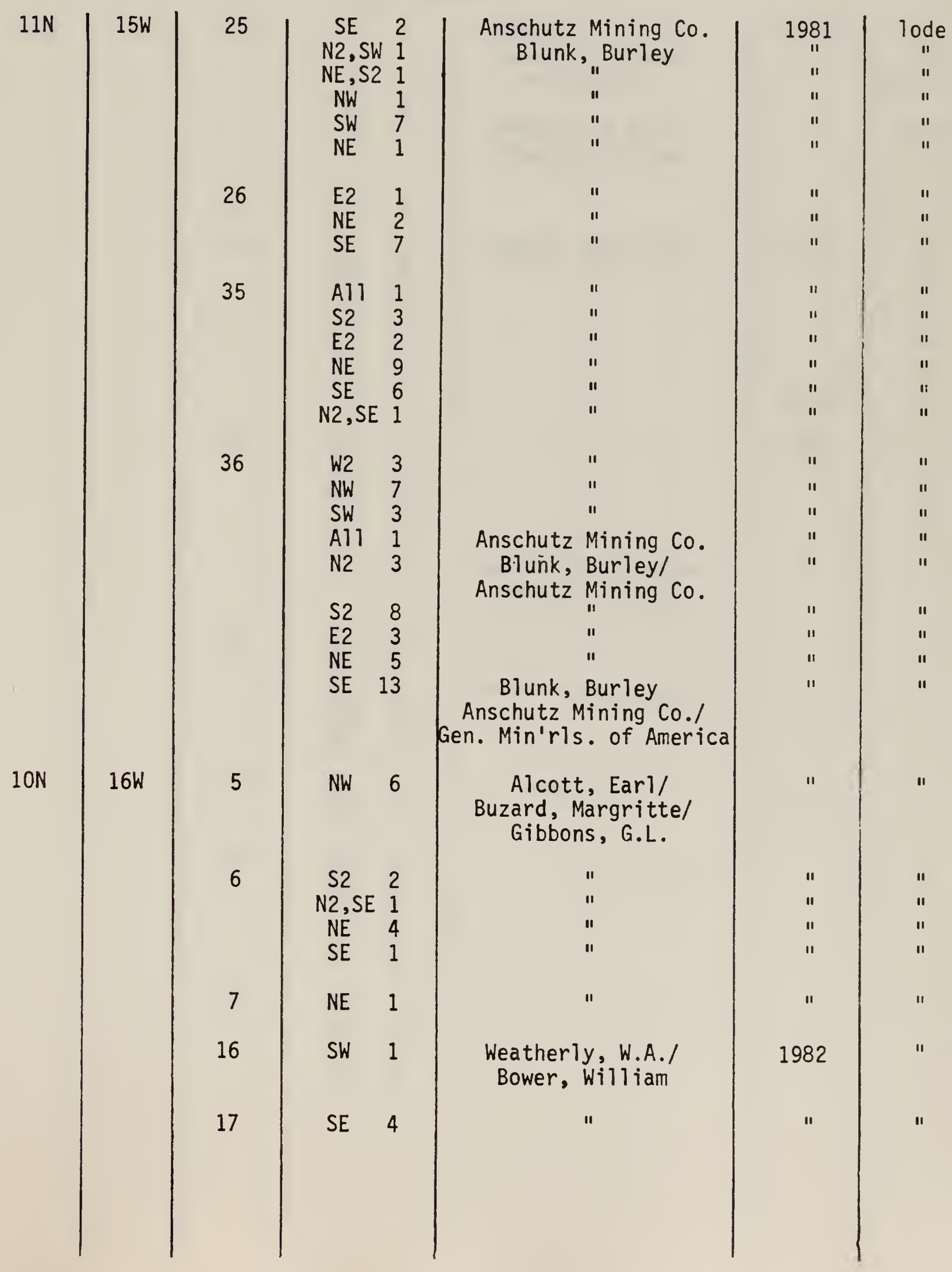


TABLE (Cont'd.)

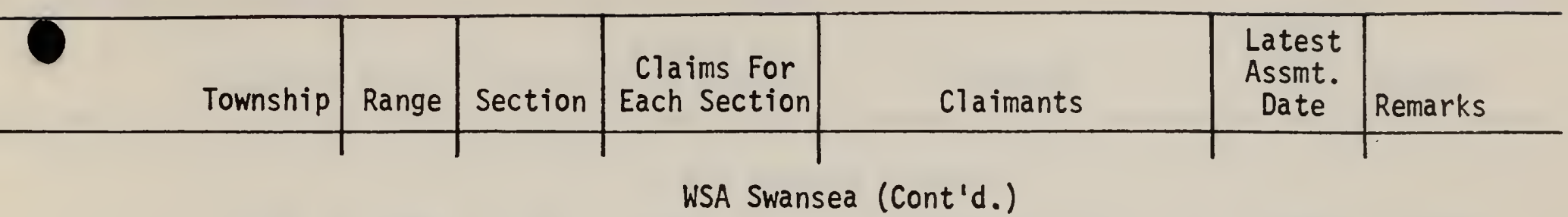

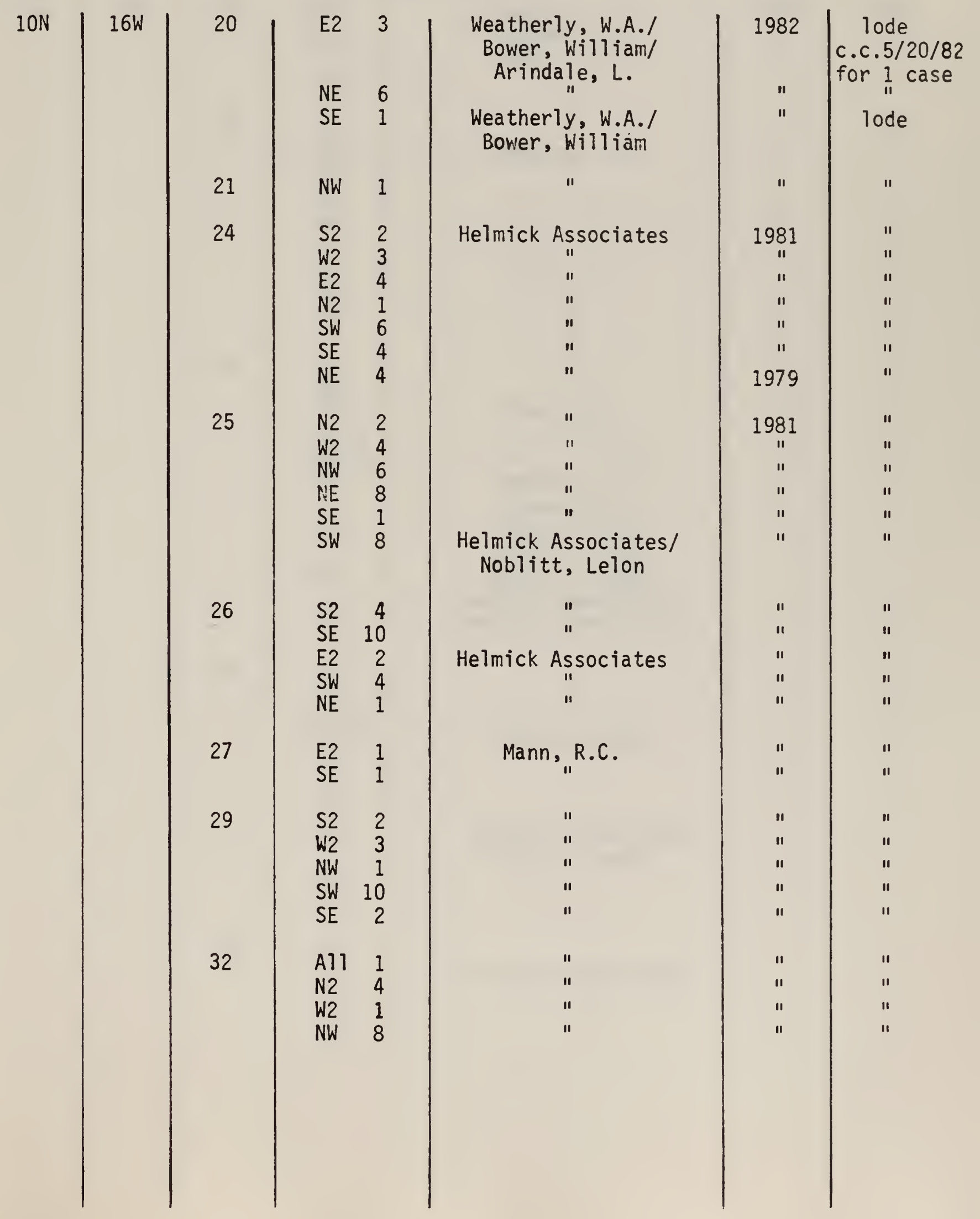


TABLE (Cont'd.)

\begin{tabular}{|c|c|c|c|c|c|c|}
\hline Township & Range & Section & $\begin{array}{l}\text { Claims For } \\
\text { Each Section }\end{array}$ & Claimants & $\begin{array}{c}\text { Latest } \\
\text { Assmt. } \\
\text { Date }\end{array}$ & Remarks \\
\hline \multicolumn{7}{|c|}{ WSA Swansea (Cont'd.) } \\
\hline $10 N$ & $16 \mathrm{~W}$ & 36 & $\begin{array}{cc}\text { NE, S2 } & 1 \\
\text { N2, SW } & 1 \\
\text { SE } & 8 \\
\text { NE } & 4\end{array}$ & $\begin{array}{c}\text { Helmick Associates } \\
\text { " } \\
" 1\end{array}$ & $\begin{array}{c}1981 \\
" 1 \\
" \\
"\end{array}$ & $\begin{array}{c}\text { lode } \\
11 \\
" 1\end{array}$ \\
\hline
\end{tabular}

WSA 050-012 Gibralter Mountain

\section{$9 N$}


TABLE (Cont'd.)

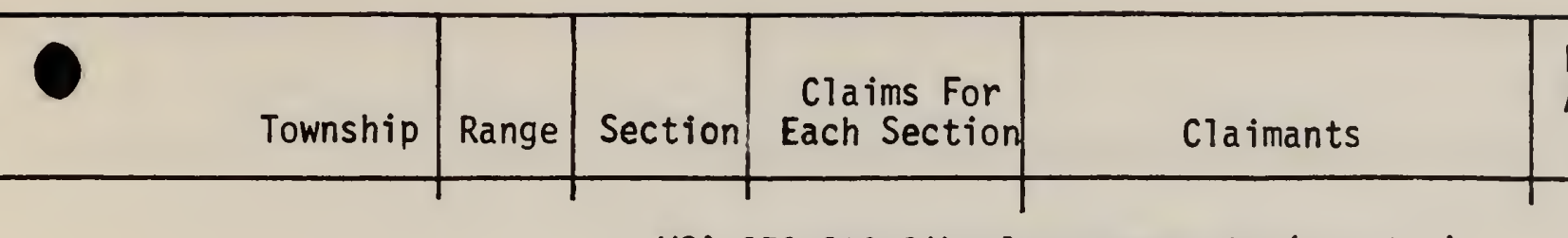

Latest

Assmt.

Date Remarks

WSA 050-012 Gibralter Mountain (Cont'd.)

$10 N$

18W

King, Thomas

11
11
11
11

19

S2 4

W2 1

NE 1

J.B. Roberts Associates

Roberts, J.B./

Crowley, Blanche/

Patrick, Lois/

Gibson, Louise/

Flowers

Roberts, J.B.I

Crowley, Blanche/

Patrick, Lois/

Gibson, Louise/ Flowers/

J.B. Roberts Associates/ Huckaby, Norma

20

N2 3

E2 1

NW 1

NE 5

SE 9

21

25

30
King, Thomas

"

"

"I

"

"

"

Woodis, Louis/

Huckaby, Norma

J.B. Roberts Associates/

Huckaby, Norma

Huckaby, Norma

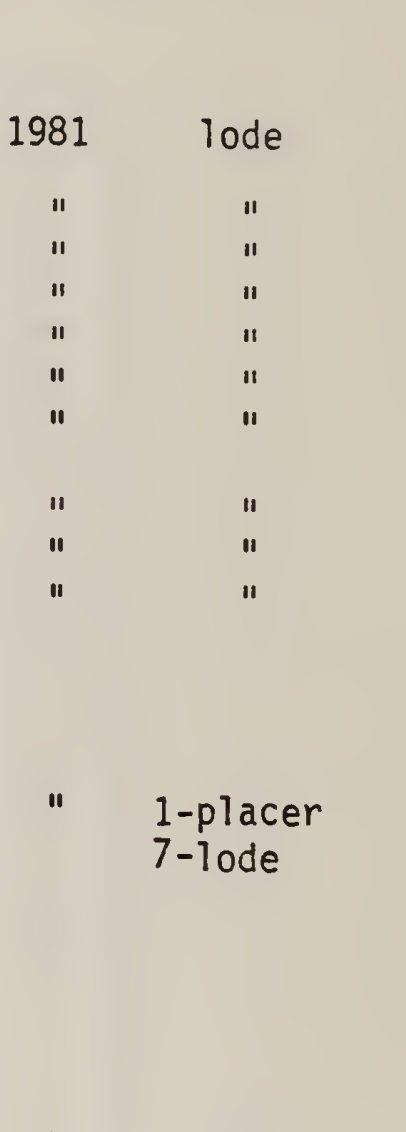

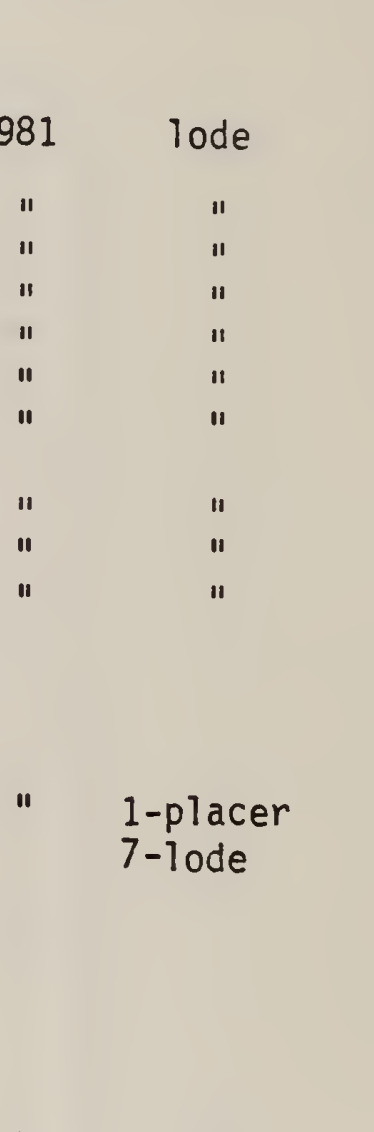

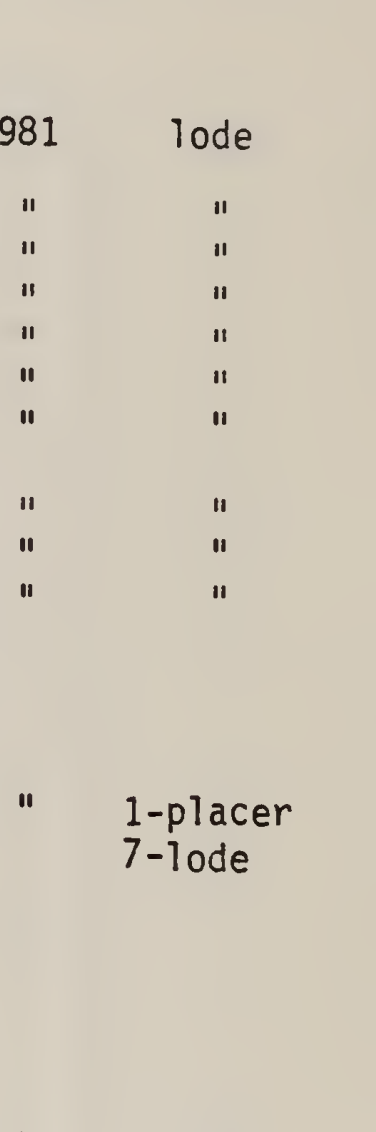

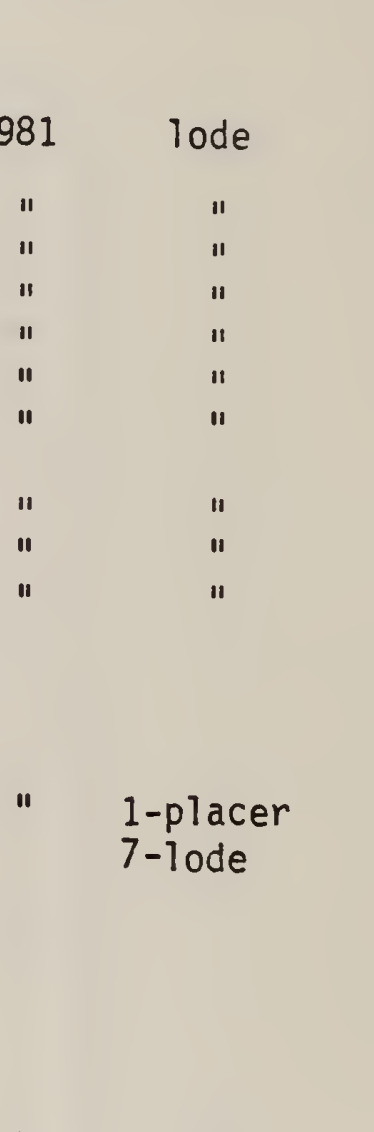

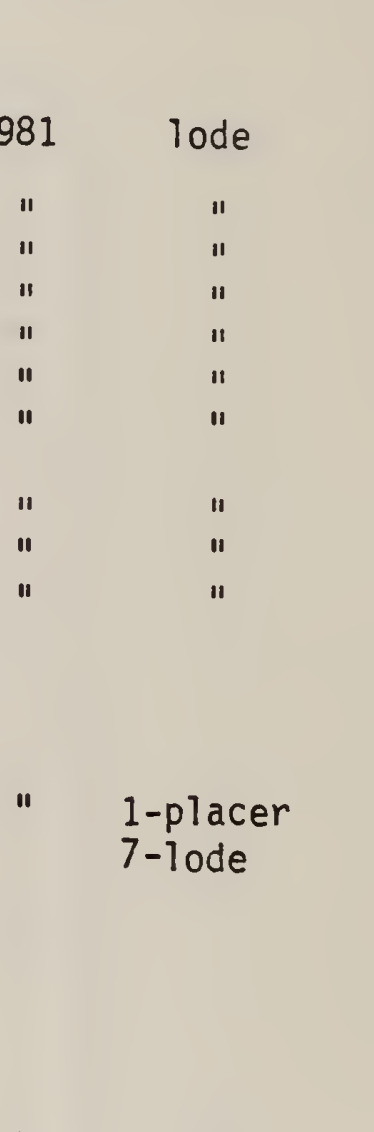

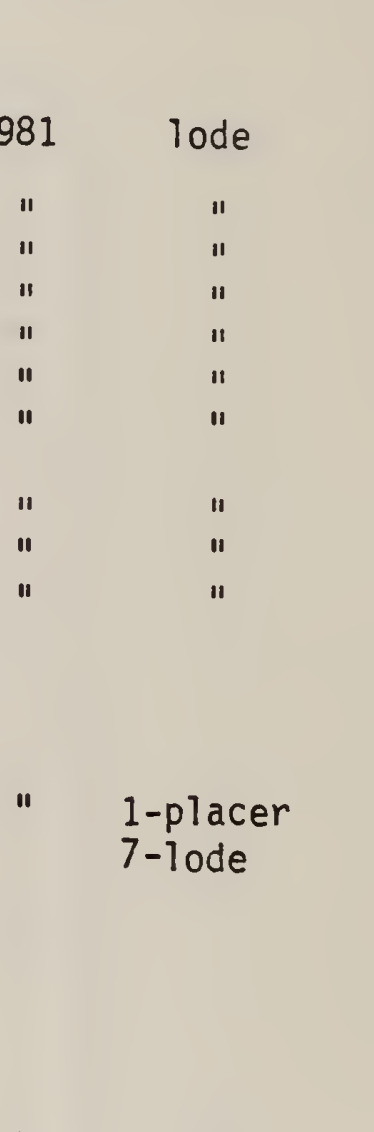

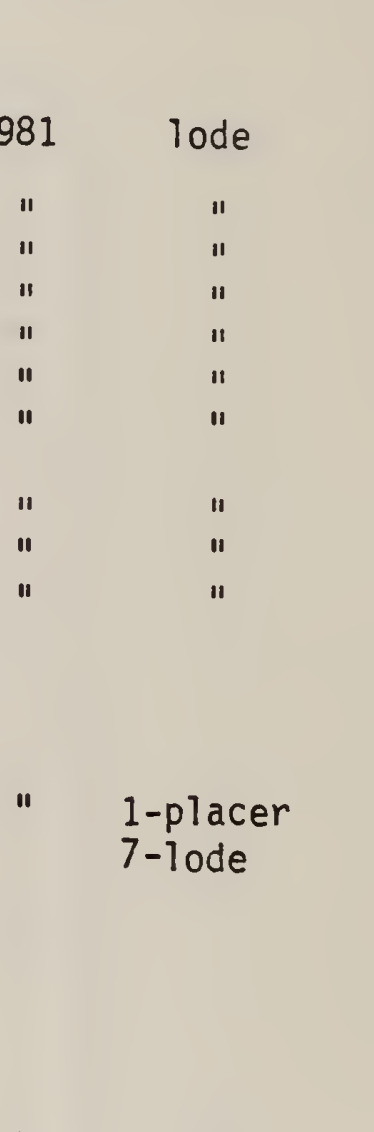

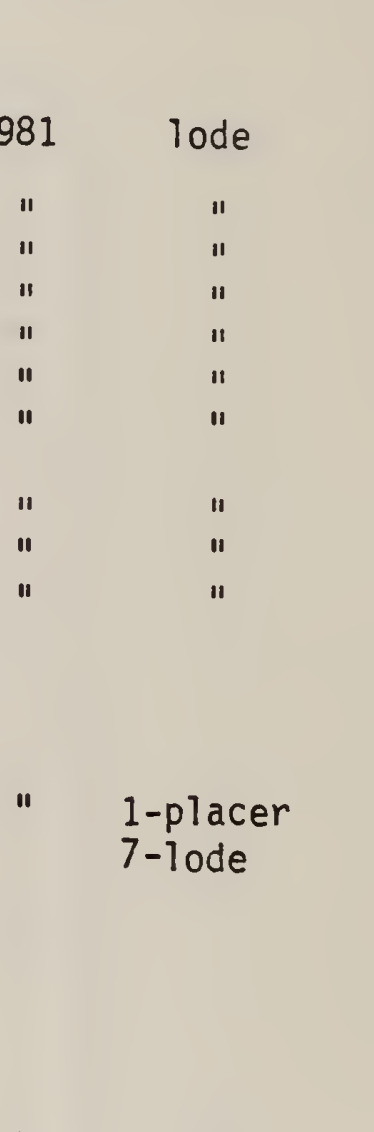

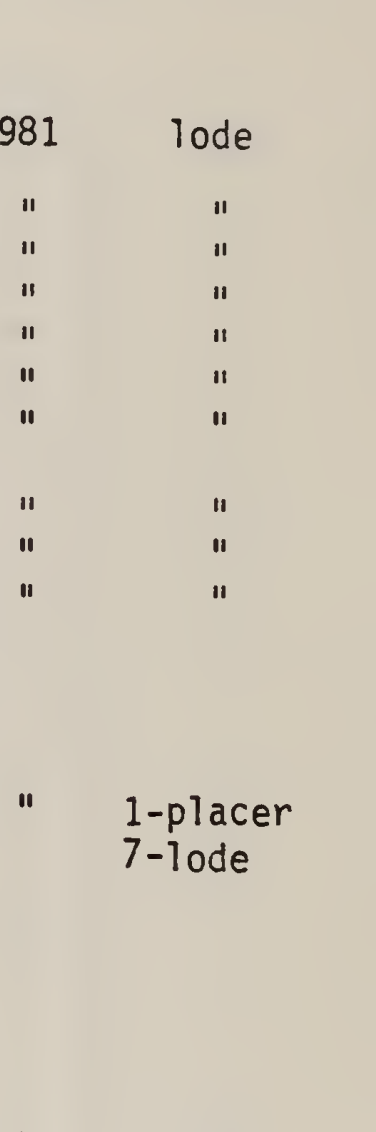

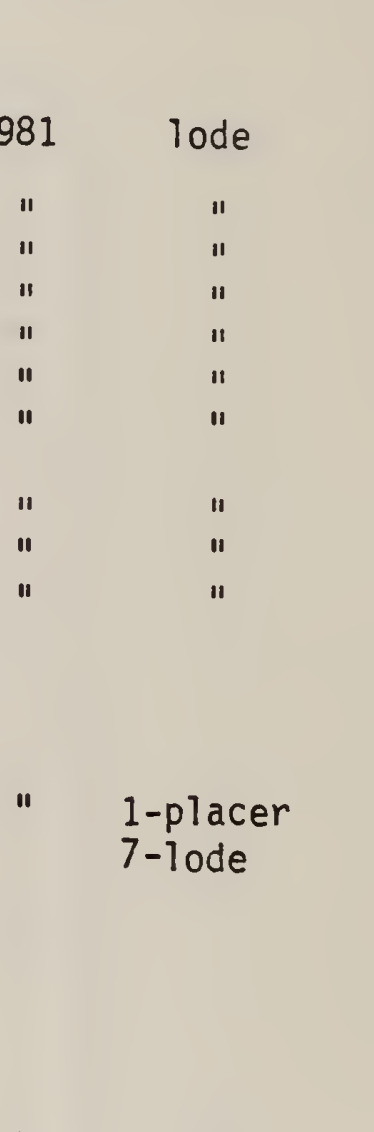

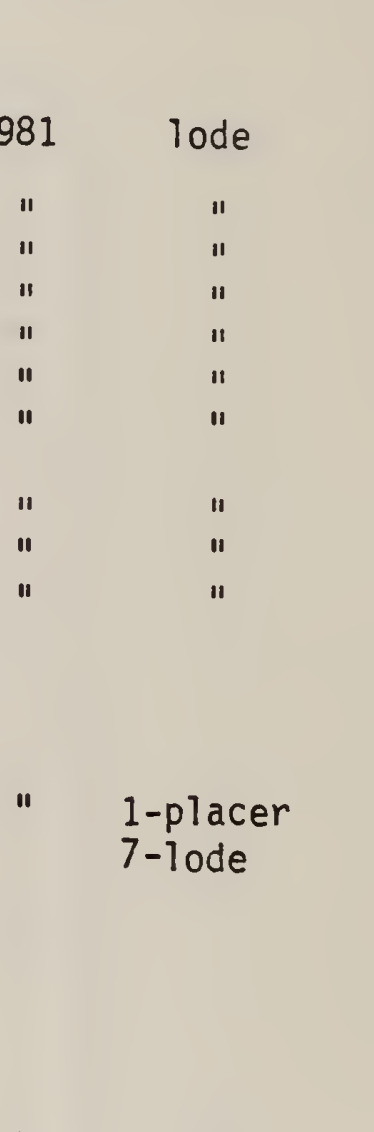

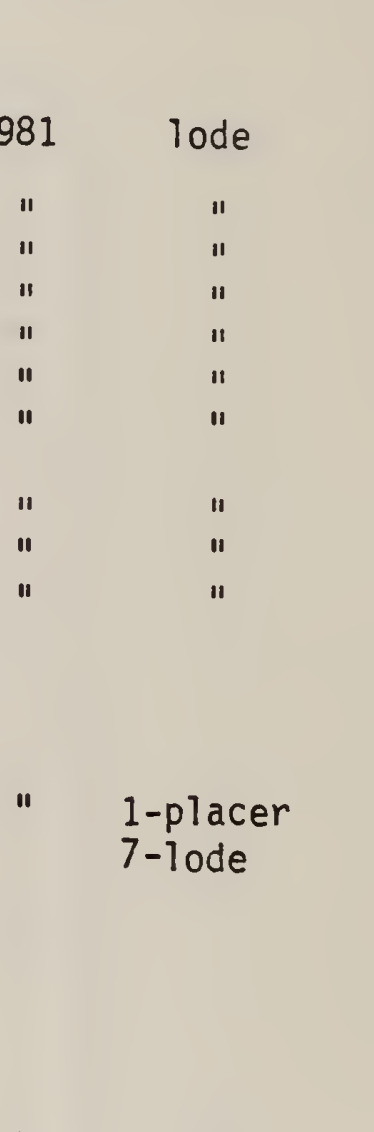

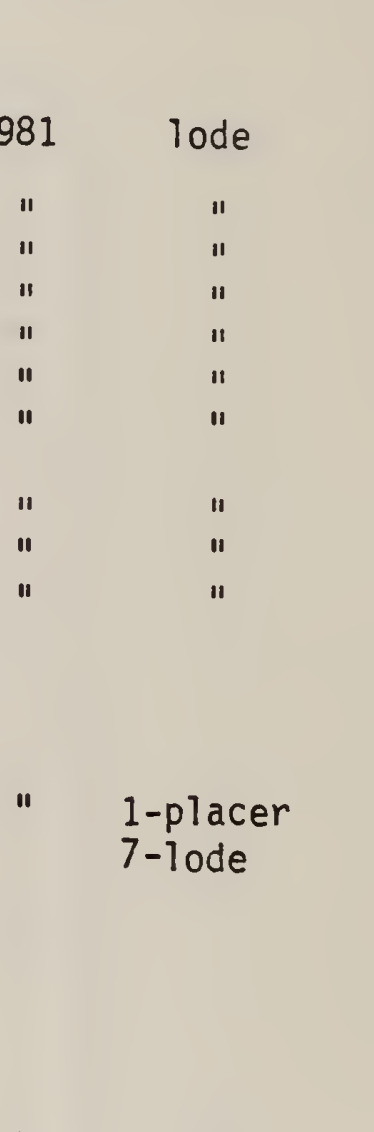

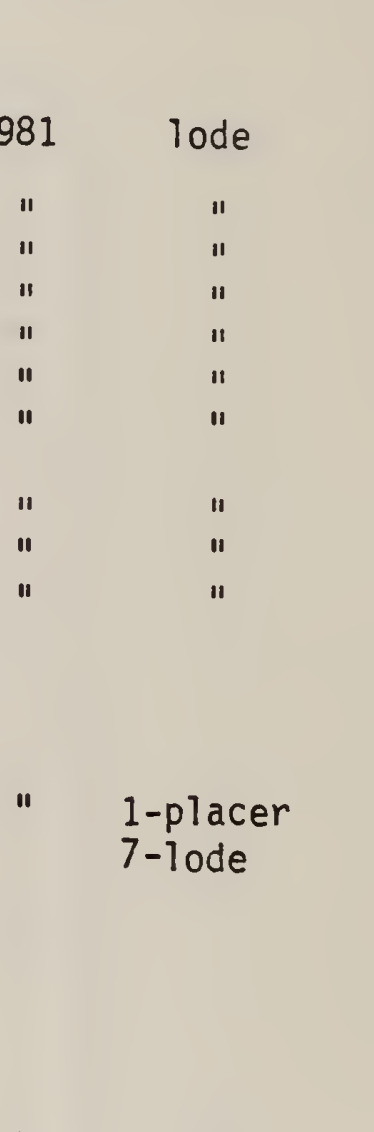

$$
\text { II }
$$

$$
\text { II }
$$

$$
\text { II }
$$

$$
\text { II }
$$$$
\text { II }
$$

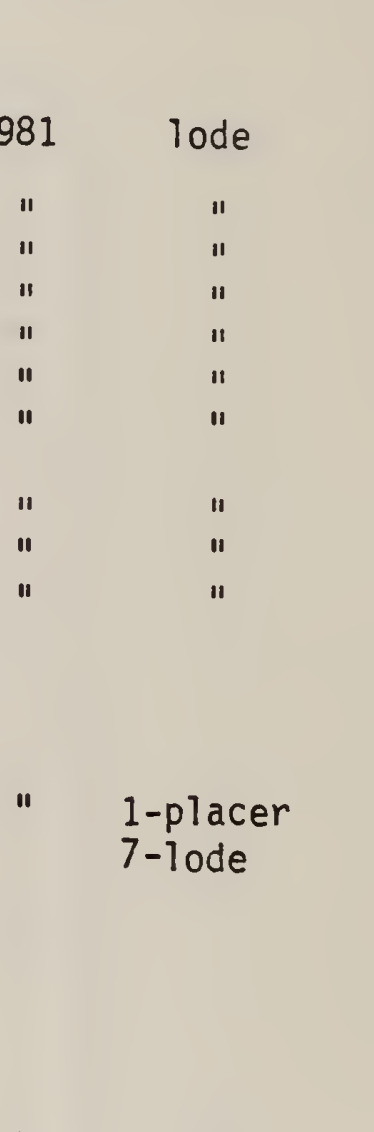

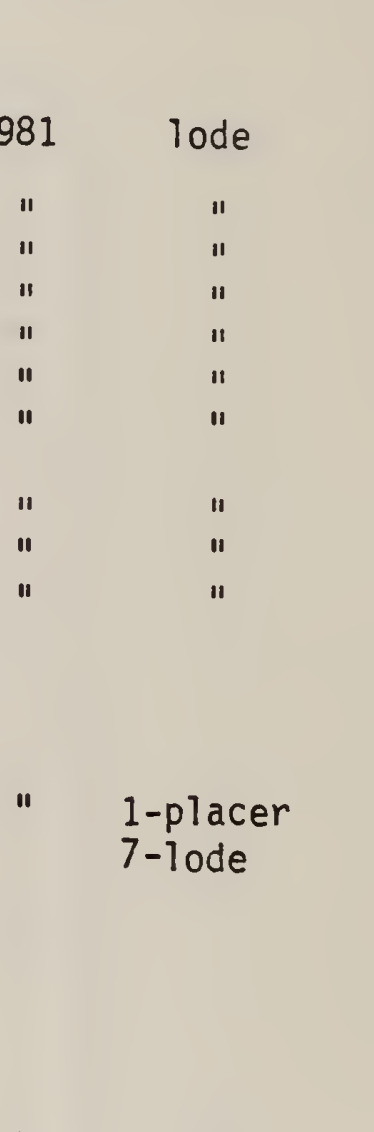

!?

II

11

II

II

$"$

"

" placer

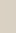

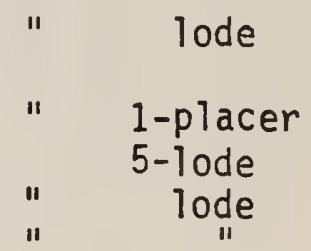


$-84-$

TABLE (Cont'd.)

\begin{tabular}{ll|l|l|l|l|l|l}
\hline Township & Range & Section & $\begin{array}{c}\text { Claims For } \\
\text { Each Section }\end{array}$ & Claimants & $\begin{array}{c}\text { Latest } \\
\text { Asst. } \\
\text { Date }\end{array}$ & Remarks \\
\hline & & & & & &
\end{tabular}

WSA 050-014 A/B Cactus Plain (Cont'd.)
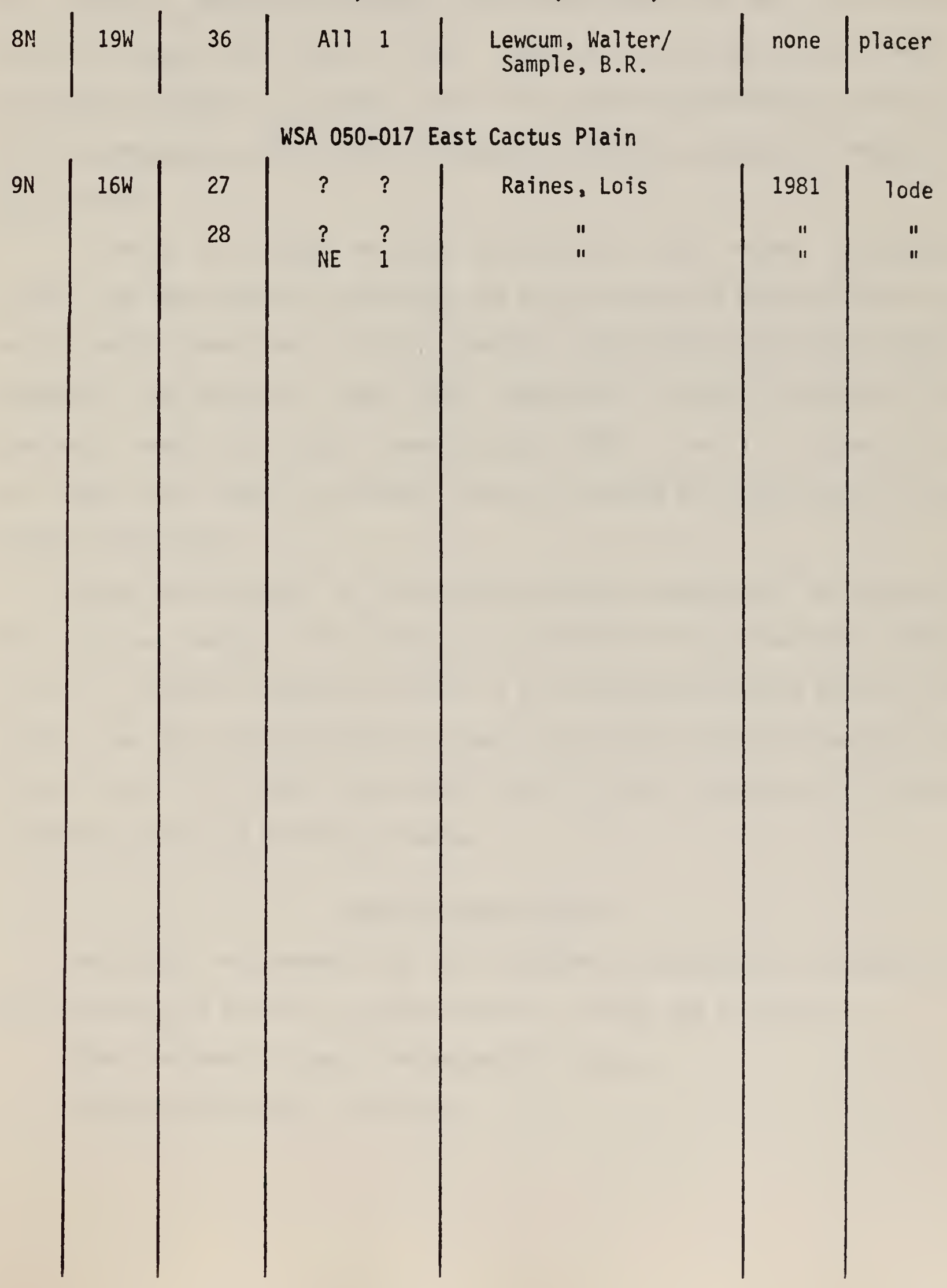

No mining claims are located in the Needles Eastern Addition (050-005B) WSA of the Havasu sub-area, but the northern half of the WSA is leased for oil and gas.

In the Buckskin sub-area (table 2) patented claims are located within the Gibraltar Mountain (050-012) and Swansea (050-015A) WSAs, while other patented claims are located within a mile of the boundaries of all WSAS. Unpatented claims are located only in the Swansea (050-015A) WSA. Most of land encompassed by WSA boundaries within the Buckskin sub-area is leased for oil and gas.

In spite of special efforts, particularly with regard to patented claims, we were unable to determine the specific types of mineralization for which these claims were filed. However, many claims coincide with mining prospects and mines of which main commodities are also indicated on the geologic, energy and mineral resources maps (figs. 3 and 4 ). It should al so be noted that mining regulations deter or prevent many people from filing claims within WSAs.

During this study, we have also thoroughly investigated the status of oil and gas leases. As a result, an outline of all land currently either fully or partially leased within and in close proximity of each specific WSA within the Bill Willliams GRA is shown together with the claim density (see figs. 7 and 8 ). Much of the federal and fee land is leased for $0 i 1$ and gas exploration for five or ten year terms.

\section{Mineral Deposit Types}

Geological environments to be considered as potentially favorable for the occurrence of mineral or energy resources include the following:

older Precambrian igneous and metamorphic rocks, Paleozoic and Mesozoic sediments, 

Laramide intrusive rocks,

mid-Tertiary metamorphic core complexes,

mid-Tertiary volcanic rocks,

mid-Tertiary basin-fill sediments,

Late Tertiary basin-fill sediments,

Recent Alluvium, and

active geothermal systems.

Table 3 shows the geological environments and associated mineral deposit types.

\section{Precambrian}

Ore deposit types that may have formed during the Precambrian include volcanigenic massive sulfide deposits and hydrothermal deposits associated with Precambrian intrusive activity or metamorphism.

Numerous occurrences of massive sulfide deposits are found in older Precambrian rocks in Arizona. They are invariably associated with submarine rhyolitic volcanism (Donnelly and Hahn, 1981), and are either of the copper-rich proximal type or the zinc and lead-rich distal type (Anderson and Guilbert, 1979). They are commonly associated with banded iron formations which are zoned, with sulfide facies near the rhyolitic center and carbonate and oxide facies further away (Anderson and Guilbert, 1979). Metavolcanic rocks occur in the Yavapai Series and in the gneissic terrain to the northwest and both lie to the northwest of the Holbrook line which separates them from the non-volcanigenic Pinal Schist (see fig. 2a). The GRA is probably largely underlain by gneissic metavolcanic terrain and Precambrian granitic intrusives.

To the north of the GRA, in the west-central Hualapai Mountains, massive sulfide deposits with pyrrhotite, sphalerite, chalcopyrite, pyrite, magnetite 

Table 3. GEOLOGICAL ENVIROMENTS OF THE BILL WILLIAMS AREA AND ASSOCIATED POTENTIAL MINERAL DEPOSIT TYPES

\begin{tabular}{|c|c|c|c|c|c|c|c|c|c|c|}
\hline $\begin{array}{l}\text { MINERAL } \\
\text { DEPOSIT } \\
\text { TYPE } \\
\text { GEOLOGICAL } \\
\text { ENVIROMENT - } \\
\text { HOST ROCKS }\end{array}$ & 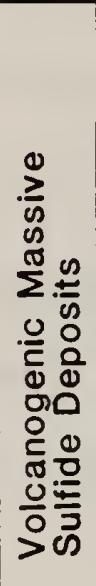 & 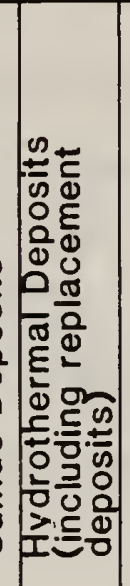 & 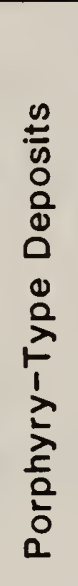 & 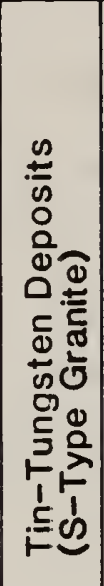 & 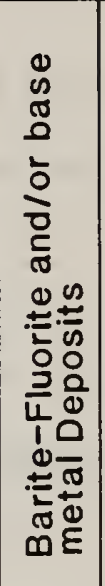 & 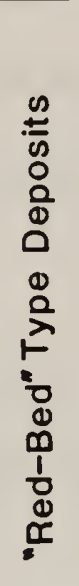 & $\begin{array}{l}0 \\
\stackrel{0}{0} \\
0 \\
0 \\
0 \\
0 \\
\frac{0}{0} \\
0 \\
\frac{\pi}{0}\end{array}$ & 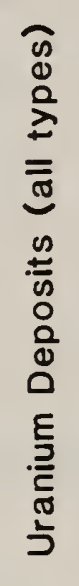 & 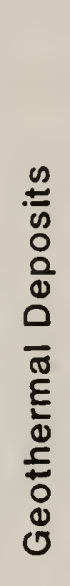 & 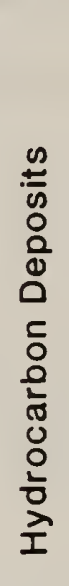 \\
\hline $\begin{array}{l}\text { Active Geothermal } \\
\text { Systems }\end{array}$ & & & & & & & & & $\mathbf{X}$ & \\
\hline $\begin{array}{l}\text { Tertiary and Quaternary } \\
\text { Alluvium }\end{array}$ & & & & & & & $X$ & & & \\
\hline $\begin{array}{l}\text { Mid- and Late Tertiary } \\
\text { Basin-Fill Sediments }\end{array}$ & & & & & & & & $\mathbf{X}$ & $X$ & \\
\hline $\begin{array}{l}\text { Mid-Tertiary Volcanic } \\
\text { Rocks }\end{array}$ & & $X$ & & & $\mathbf{X}$ & & & & & \\
\hline $\begin{array}{l}\text { Mid-Tertiary Metamorphic } \\
\text { Core Complexes } \\
\text { (including upper plates) }\end{array}$ & & $X$ & & & & & & $X$ & & \\
\hline $\begin{array}{l}\text { Laramide Intrusive } \\
\text { Rocks }\end{array}$ & & & $X$ & $X$ & & & & & & \\
\hline $\begin{array}{l}\text { Paleozoic and Mesozoic } \\
\text { Sediments }\end{array}$ & & & & & & $X$ & & & & $\mathbf{X}$ \\
\hline $\begin{array}{l}\text { Older Precambrian } \\
\text { Igneous and } \\
\text { Metamorphic Rocks }\end{array}$ & $\boldsymbol{\lambda}$ & $\boldsymbol{\lambda}$ & & & & & & & & \\
\hline
\end{tabular}


and galena, and banded iron formations are associated with rhyolitic metavolcanic rocks (Stensrud and More, 1980). No similar occurrences are known in the GRA.

In the Mohave Mountains in the Havasu sub-area, gold-tungsten veins are present in Precambrian gneiss and schist. One of the veins (description \#40) has reported minor production. It contains wolframite and hematite and is possibly associated with nearby granitic intrusive. Other gold-tungsten occurrences (70-75) are widely scattered in the Mohave Mountains and could be related to granitic intrusion or a Precambrian metamorphic event.

\section{Paleozoic and Mesozoic Sediments}

Paleozoic and Mesozoic sediments are potential host rocks for accumulation of hydrocarbons and possibly red-bed type copper and silver deposits.

In southwestern Arizona, Paleozoic and Mesozoic sediments, especially in the possible extension of the Overthrust Belt, have been considered potentially favorable for the accumulation of hydrocarbons (Keith, 1980; Peirce, 1982). All exploration wells drilled to date however, have been dry (Peirce, 1979; Keith, 1981; Peirce, 1982; see also fig. 9). In the Bill Williams GRA, three such holes have been drilled close to the eastern and western boundaries of the Buckskin sub-area (see fig. 9). Existence of the Overthrust Belt in Arizona is yet to be proven (Peirce, 1982). Southern Arizona has been subjected to more orogenic activity than the Overthrust Belt of Utah, Wyoming and Montana, decreasing the possibility that hydrocarbons, if ever present, remain in the rocks (J. Rizo, written comm.).

Undifferentiated Paleozoic sedimentary rocks crop out in the Buckskin and Rawhide Mountains, and in the upper plates of metamorphic core complexes. Potential source rocks for hydrocarbons are the shales and fetid limestones 



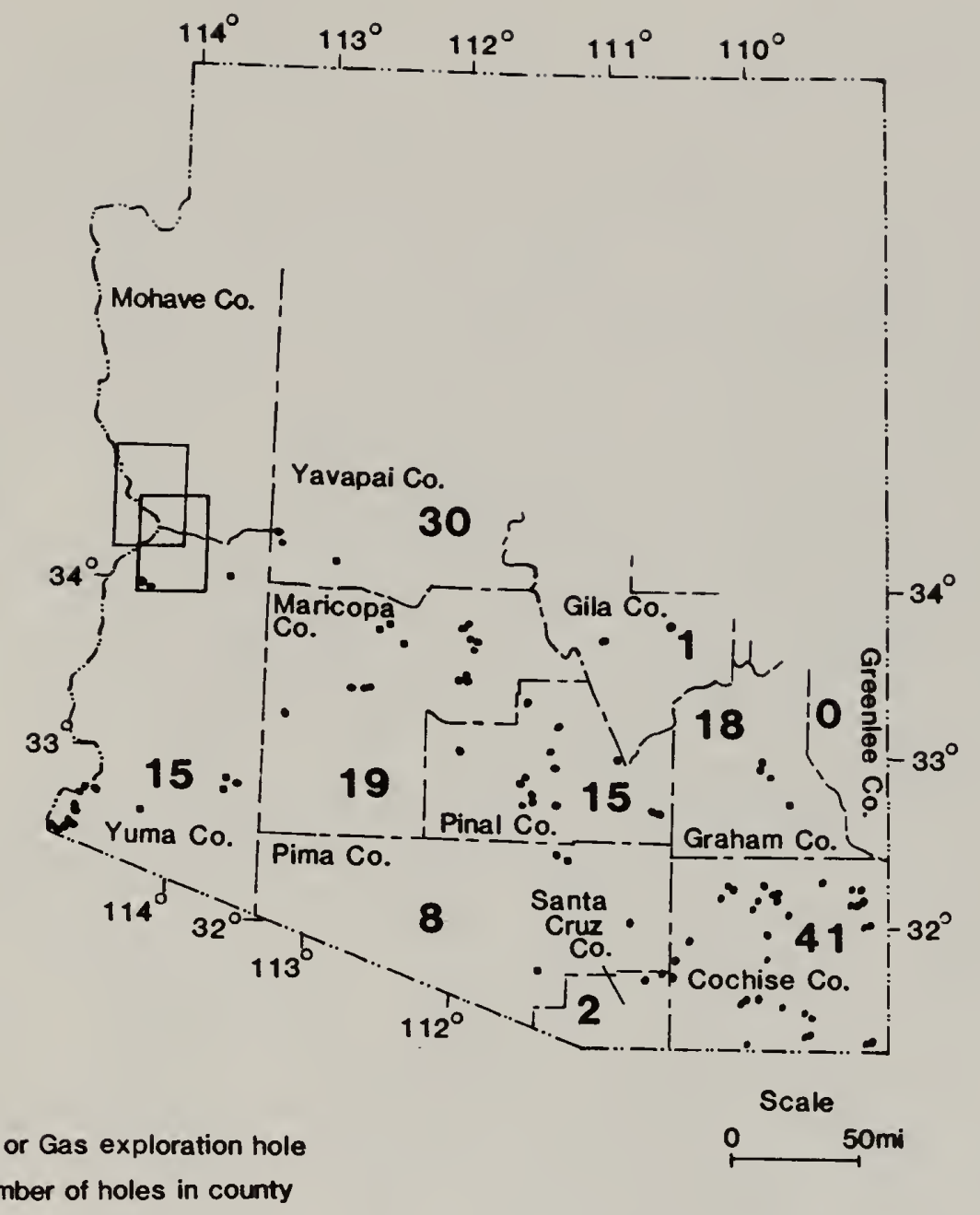

FIG. 9 LOCATION OF OIL AND GAS EXPLORATION HOLES IN SOUTHERN ARIZONA, after Jones (1979). 
in the Abrigo and Martin formations. Potential resevoir rocks include the above-mentioned formations, the Supai Formation and the Coconino Sandstone. The Mesozoic sediments crop out in southern Buckskin sub-area and are non-marine, are not known to be rich in organic matter and are unlikely to be good source rocks for hydrocarbons. Locally, they could be effective reservoir rocks.

Both the Paleozoic and Mesozoic sediments have undergone deformation during the mid-Mesozoic, Laramide and mid-Tertiary orogenies, and during Basin and Range faulting. They have been metamorphosed and are structurally highly complex. Thus, they are not considered favorable for the accumulation of hydrocarbons. It should be noted however, that there has been recent drilling activity in southern Arizona, based on a reinterpretation of seismic data which suggests that extensive thrust sheets are present in the area (Keith, 1980; Peirce, 1982). According to this interpretation rocks cropping out at the surface have been thrust over Paleozoic and Mesozoic sediments which are potentially favorable for the accumulation of hydrocarbons. We have no data to support or refute this except to note that one hole drilled near Florence on the basis of such an interpretation bottomed in granite at 18,000 feet (Keith, 1981).

Thick Mesozoic red-beds crop out in the Plomosa Mountains within the Kofa GRA and may extend into the southern part of the Buckskin sub-area. Such beds are potentially favorable for red bed-type, copper-silver deposits such as are present in Permian and Triassic sediments in central and northern New Mexico (LaPoint, 1974a, 1974b). No occurrences of this sort are known in the GRA, but the presence of permeable red-beds interbedded with playa and evaporite deposits in the Mesozoic sedimentary rocks suggests that a favorable environment for such deposits could be present. 


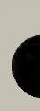

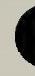




\section{Laramide Intrusives}

The Laramide was a time of emplacement of all but one (Bisbee) of the porphyry copper deposits in Arizona and adjacent New Mexico and Mexico. of the 35 major porphyry copper deposits in this region, 32 lie to the southeast of the Holbrook line where basement is the Pinal Schist and three lie to the northwest where basement consists of Yavapai Series and gneissic-metavolcanic terrain (see fig. 2C). The intrusives associated with the porphyry copper deposits were emplaced during the westward sweep of the magmatic arc (Damon et al., 1981; Clark et al., 1982), possibly related to the decrease in the dip of the Benioff zone at this time (Coney and Reynolds, 1977). The porphyry copper deposits appear to be aligned along northwest and east-northeast trends (Heidrick and Titley, 1982; see fig. 2C). The northwesterly trend is sub-parallel to Mesozoic linear discontinuities in depositional patterns (Titley, 1976); the trend of Laramide basement-cored uplifts and thrust faults (Nielson, 1979; Davis, 1981); the Texas zone of Schmitt (1966); and the trend of the Laramide magmatic arcs. The ENE trend is sub-parallel to Precambrian fold axes and Laramide tensional features (Rehrig and Heidrick, 1976). The intrusions related to the porphyry copper deposits are small in area (seldom over $3 \mathrm{~km}^{2}$ ) and may have been emplaced along the NW and ENE structural intersection (Titley, 1981).

No porphyry copper-type mineralization is known to occur within the GRA which lies almost entirely outside the northwest and east-northeast-trending belts of porphyry copper deposits (see fig. 2C). Laramide intrusives within the GRA are restricted to the metamorphic core complexes and there appears to be no known mineralization associated with them. The reason for this is not known but could be one or more of the following factors:

1. The GRA is largely underlain by Precambrian metavolcanic gneiss 


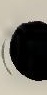

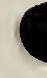


basement, whereas 32 of 35 major porphyry copper deposits in the southwest are in a region where the basement consists of Pinal Schist (see fig. 2C).

2. Most of the Laramide intrusions in this area are peraluminous, possibly S-type granites, which, according to Burnham (1981) are generally not associated with porphyry coppermolybdenum-gold deposits, but rather tin-tungsten deposits.

3. Erosion during post-Laramide time may have progressed to deep levels, removing shallower parts of intrusions where ore deposits may have been present. The presence of muscovite in some of the intrusives suggests that the level of exposure is indeed deep.

4. The GRA is extensively covered by mid-Tertiary and late Tertiary sediments and volcanics which may hide porphyry copper deposits.

In the light of the above discussion it is considered that overall the GRA has only a low favorability for the occurrence of porphyry copper and related deposits.

\section{Mid-Tertiary Metamorphic Core Complexes}

The potential for mineral deposits associated with metamorphic core complexes is not well known as it is only during the last ten years or so that the complexes themselves have been widely recognized. In an important work, Coney and Reynolds (1980) and several co-workers have attempted to assess uranium favorability of these complexes and in so doing they have also provided useful information on some other elements. Some important findings of this study which also includes the report by Keith and Reynolds (1980) and Reynolds (1980) are as follows: 
1. Uranium related to plutonic processes tends to be associated with potassium-rich rocks $\left(\mathrm{K}_{2} \mathrm{O}>4 \%\right)$.

2. Uranium related to metamorphic processes may be transported by fluids released through dehydration reactions. Geochemical studies by Keith and Reynolds (1980) show that mylonitization is not associated with any changes in $U$ or Th concentration. However, the rich uranium deposit of Graeber Lease in the Kettle Metamorphic Core Complex, Washington, occurs in mylonitic gneisses and may be of metamorphic origin (Reynolds, 1980).

3. The dislocation surface and the underlying chloritic breccia represent a permeable horizon along which fluids migrated (Reynolds, 1980). Geochemical studies in the Rawhide Mountains by Keith and Reynolds (1980) show that these rocks are enriched in $\mathrm{U}, \mathrm{Th}, \mathrm{CU}, \mathrm{Zn}, \mathrm{Fe}, \mathrm{V}, \mathrm{Li}$ and $\mathrm{Cr}$ compared to the protolith, contain uranium occurrences, and more widespread hematite, limonite, $\mathrm{Cu}$, and Au mineralization. Coney and Reynolds (1980) consider that investigation of these zones down dip into the nearby basins may be worthwhile.

In the Bill Williams GRA, numerous mineral deposits and occurrences appear to be associated with metamorphic core complexes. In the Midway Mining District, $\mathrm{Cu}, \mathrm{Au}, \mathrm{Ag}$, barite, and fluorite mineralization, with minor production, occur along shear zones within the metamorphic core close to or along the dislocation surface with overlying Mesozoic metasediments.

In the Santa Maria Mining District, $\mathrm{Cu}, \mathrm{Fe}, \mathrm{Mn}, \mathrm{Au}$ and $\mathrm{Ag}$ mineralization occur along faults in Precambrian gneiss, and Paleozoic limestone and quartzite, along or close to the dislocation surface and along what are probably listric normal faults in the upper plate. The ore deposits contain 
copper oxides, silicates, carbonates and some sulfides, hematite, pyrolusite, psilomelane and native gold. 1.4 million tons of ore containing 23,000 tons $\mathrm{Cu}, 35,000 \mathrm{oz}$. Ag, $1008 \mathrm{oz}$. Au and 400 tons $\mathrm{Mn}$ have been produced from the district.

In the Cienega Mining District, $\mathrm{Cu}, \mathrm{Au}, \mathrm{Ag}$ and minor $\mathrm{Pb}, \mathrm{Ag}, \mathrm{W}, \mathrm{U}$ and $\mathrm{Ba}$ occur as replacement bodies along faults between metamorphosed Paleozoic limestone and quartzite and Precambrian metamorphics. In the southeastern part of the district the mineralization lies close to or along the dislocation surface. In the remainder of the district the mineralization is in the upper plate, possibly along listric normal faults associated with late phases of metamorphic core complex emplacement. The ore contains copper silicates, carbonates, oxides and sulfides at depth, native gold and hematite. 19,000 tons of ore containing 917 tons $\mathrm{Cu}, 11,707 \mathrm{oz}$. Au, $3304 \mathrm{oz}$. Ag were produced from the district.

Overall the metamorphic core complexes are moderately favorable environment for $\mathrm{Cu}, \mathrm{Au}$ and $\mathrm{Ag}$ deposits. The deposits formed along fracture zones related to dislocation surfaces and listric normal faulting. Circulation of the metal-bearing fluids may have resulted from temperature gradients associated with the emplacement of the metamorphic core complexes themselves and/or with Mid-Tertiary volcanism. The presence of oxide, carbonate, silicate, sulfate minerals suggests that conditions during deposition were oxidizing and probably formed at shallow depth. It is possible that more reducing, sulfide-rich assemblages may be present at depth.

\section{Mid-Tertiary Volcanic Rocks}

Mid-Tertiary volcanics in southern Arizona, southwestern New Mexico and Mexico are associated with gold-silver and base metal lode deposits (Damon et 
al., 1981; Clark et al., 1982). The volcanics were erupted when the magmatic arc swept rather rapidly westward, possibly as a result of the steepening of the Benioff zone (Coney and Reynolds, 1977). In southwestern New Mexico the deposits are associated with cauldrons from which voluminous ignimbrites and other volcanics were erupted (Elston, 1978). As yet, no such cauldrons have been identified in Arizona, but the voluminous ignimbrites and presence of numerous deposits suggest that such cauldrons could be present.

Mid-Tertiary andesitic volcanic rocks crop out in south-central Buckskin sub-area and west-central and northwestern Havasu sub-area. Mid-Tertiary intrusives are widespread over most of the GRA, but the largest intrusive crops out in the southeastern part of the Buckskin sub-area.

In the Plomosa Mining District and in the area to the east, barite-fluorite veins occur along breccia zones in Mesozoic schist which is intruded by rhyolite, and in fractures in Tertiary agglomerate; pyrolusite and psilomelane occur along faults in Mid-Tertiary andesites and sediments, and Mesozoic schist and limestone; and $\mathrm{Au}, \mathrm{Ag}$ and base metals occur along faults in Mesozoic shales close to Tertiary diorite porphyry and granite porphyry, near thrust faults (or listric normal faults?) involving Precambrian gneiss, Mesozoic schist and Tertiary sediments, and in Tertiary andesites. 26,000 tons of ore were produced from the district, which lies mostly to the south of the GRA (see Kofa GRA report). Much of the ore represents oxidizing conditions of deposition and it is possible that more reducing sulfide-rich assemblages are present at depth.

Several small manganese occurrences are located in the Havasu sub-area. They are located along shear zones cutting Tertiary volcanics and sediments and Precambrian gneiss and are probably associated with Tertiary volcanism. 


\section{Mid-Tertiary Sediments}

Mid-Tertiary valley-fill sediments are widespread in southwestern Arizona and since the discovery of the Anderson Mine (Sherborne et al., 1979) have become a prime target for uranium exploration. The Anderson Mine itself, located about 20 miles east of the GRA, has reserves of nearly 3 million pounds of $\mathrm{U}_{3} \mathrm{O}_{8}$, a figure in excess of previously quoted estimates for the entire Basin and Range province (Sherborne et a1., 1979).

In order to form a uranium deposit by the agencies of circulating groundwater or connate water, it is necessary to have adequate uranium source rocks, permeable sediments for the water to flow through, and a reductant to precipitate the uranium. Suitable source rocks are plentiful in southwestern Arizona and in the GRA. Their distribution is shown in figure 2D (after Scarborough and Wilt, 1979), and they include Precambrian alkalic and alkali-calcic granites, alkali-calcic Tertiary volcanics and metamorphic core complexes which contain two-mica granites, uranium enriched detachment zones and chloritic breccias (see previous section). Particularly good sources of uranium are potassium-rich igneous rocks (Keith and Reynolds, 1980). In the Anderson Mine, the source of the uranium is postulated to be tuffaceous lake sediments from which connate water and uranium were squeezed out during compaction (Sherborne et al., 1979). Such tufaceous lacustrine sediments are common in the mid-Tertiary sequence, especially in the middle and upper part of Unit I of Eberly and Stanley (1978). Permeable horizons suitable for transport of uranium, especilly fluvial reddish sandstones and gravels are plentiful within the Tertiary sequence. Reductants are also locally present. At the Anderson Mine, these are organic-rich mudstones (Sherborne et a1., 1979). In the Plomosa and Gila Bend Mountains there are fetid (organic?) limestones (Scarborough and Wilt, 1979). Another possible reductant is past 
and present geothermal water which even today are widely distributed in southwestern Arizona. Warm geothermal waters are present in north-central Buckskin sub-area as indicated by the presence of one warm water well (158). If such geothermal waters are reducing, and geothermal waters generally are, then precipitation of uranium could occur at the interface between oxidizing groundwater and reducing, warm geothermal water.

In the Bill Williams GRA Tertiary sediments crop out in the Whipple, Bill Williams, Rawhide and Plomosa Mountains. They probably underlie the Late Tertiary sediments in the deeper basins such as Dutch Flat, near Lake Havasu, Cactus Plain and Butler Valley. This has been shown to be the case in other parts of southwestern Arizona by Eberly and Stanley (1978) on the basis of drill hole and seismic profiling data. Tertiary sediments are also probably interbedded with units shown on the geologic maps as Tertiary volcanics. This is demonstrated by Scarborough and Wilt (1979), who show several detailed cross-sections through Tertiary volcanics in southwestern Arizona. In these volcanic rocks are shown to be interbedded with red fluvial sands and gravels and local lake beds. Such interbedding of volcanic rocks (U sources) with permeable red sediments allows for ready transport of uranium and thus enhances the favorability for uranium deposits. Two uranium occurrences are known in the GRA. The first (61), anomalous radioactivity is associated wth $\mathrm{Cu}, \mathrm{Fe}$ and $\mathrm{Mn}$ near the dislocation surface between Tertiary limestone and Precambrian gneiss. In the second (161), anomalous radioactivity occurs in sandstone and mudstone of the Artillery Formtion.

Overall the favorability for uranium deposits in Tertiary sediments is considered low to moderate. It is probably highest in the deep basins that contain silicic volcanics within them. 


\section{$\underline{\text { Late Tertiary Sediments }}$}

Late Tertiary sediments are present in all basins formed as a result of Basin and Range faulting. The depths of these basins are indicated by contours shown in figures 3 and 4 , and are interpreted from gravity data by Oppenheimer and Sumner (1981). As in the case of the mid-Tertiary sediments, adequate uranium source rocks and permeable horizons are widespread. Extensive organic reductants are not known to be present in these sediments, but the warm geothermal waters (see fig. 4) may be sufficiently reducing to cause uranium precipitation.

\section{Recent Alluvium}

Alluvium formed in present day river valleys is a possible site for concentration of placer gold and other heavy minerals. Placer gold deposits are located in the Mohave Mountains (the Chemehuevis placers, Au 84), in the Cienega District ( $\mathrm{Au}$ 100) and in the Santa Maria District (Au 85). In the Chemehuevis placers, production was between 100 and $1000 \mathrm{oz}$. Au and the gold was probably derived from Precambrian gneisses. In the Cienega placers some gold production is reported and the source of the gold is probably local hydrothermal deposits. In the Santa Maria placers production was $120 \mathrm{oz}$. Au and the source of the gold was probably the metamorphic core complex.

\section{Geothermal}

Extensive but low temperature geothermal resources are known to be present in southwestern Arizona (Jones, 1979). Factors that are favorable for the existance of substantial geothermal systems include: presence of a high temperature heat source; the presence of aquifers which allow large volumes of water to circulate through the hot rocks; and the presence of cap rocks which will prevent the escape to the surface of at least some of the 
hot fluid.

In southwestern Arizona the intensity of volcanic activity has been waning during the past 4 m.y.B.P. However, basalt flows as young as 1.3 m.y.B.P. are present (Shafiqullah et al., 1980). Aquifers and cap rocks in the form of gravel and sands, and lake beds are present in Late-Tertiary basin-fill sediments. These sediments occupy tectonic depressions resulting from Basin and Range faulting and many are over 3000 feet deep. It is within these basins that warm geothermal waters $\left(>25^{\circ} \mathrm{C}\right)$ are present.

In the Bill Williams GRA the Dutch Flat, Havasu Lake and Cactus Plain basins are over 3000 feet deep (see figs. 3 and 4). Only one warm water well has been drilled to date (158). It is located in the lowland between the Bill Williams and Rawhide Mountains and it is about 2000 feet deep and contains water at $54^{\circ} \mathrm{C}$.

\section{Mineral Economics}

The assessment of the geological, energy and mineral resources favorability should rely upon not only geology, but must. also be concerned with economic factors and priorities. Discovery, recovery, cost of production of the resource from sources with varying qualities and/or concentrations are included in those considerations. Special consideration must be given to the strategic and critical minerals and metals. As this project is of limited scope, and because of special difficulties in southwestern Arizona, economic analyses of various commodities can only be discussed briefly.

Some factors especially important to the evaluation of the mineral and energy resources of southwestern Arizona include the following:

1. The geology of the Bill Williams GRA is very complex and detailed information on the geology and mineral deposits of the WSAs is, for 
the large part, limited. This is multiplied by recent and ongoing reinterpretations of the geology of the Basin and Range in Arizona. In order to interpret the geology of the WSAs, and thus be able to project the types of mineral deposits that may be present in those areas, it is necessary to apply information about known areas of apparently similar geology to the interpretation of the geology of the WSAs. These are not optimum conditions. A wide variety of possibilities must be considered and, therefore, discussions of mineral economics must be considered tentative.

2. Contributing to the problems listed above, and creating some other distinct difficulties, are the ruggedness and roadless nature of the WSAs. Roadlessness, a criterion for WSAs, inhibits exploration and development of mineral resources due to poor access, distance to market, and other factors which increase the expense and difficulty of geological and mineral exploration.

3. A great number of commodities, including many strategic and critical minerals and metals, are known to occur in the WSAs and their surrounding areas.

4. Considering all the above mentioned problems, it is very possible that sophisticated methods currently used by professional geologic explorationists have not been fully employed in southwestern Arizona. Most of the mines and occurrences in the GRA were discovered many years ago by prospectors using simple techniques.

Much work must be done before a full evaluation of the mineral and energy resources, a prerequisite for the discussion of mineral and energy economics, can be made.

No mineral occurrences are reported to exist in the Needles Eastern Addition (050-005B) WSA of the Havasu sub-area. Three occurrences, 
commodities unknown, are located within two miles of the WSA boundary.

Descriptions of mineral occurrences located within the WSAs of the Buckskin sub-area are summarized in the following section of this report, which details the geology, energy and mineral resources of the WSAs. Due to the number of different commodities and occurrences, only brief mention will be made in this section of the report.

In the Gibraltar Mountain (050-012) WSA, seven structuraliy controlled epigenetic deposits are located within upper plate rocks of a metamorphic core complex. The deposits contain gold \pm copper, silver and iron. Copper and silver are classified as strategic and critical commodities. three deposits have significant reported production of copper and/or gold and silver. One gold placer within the WSA recorded minor production.

Five mineral occurrences, all associated with a metamorpic core complex, are located within the Planet Peak (050-013) WSA. Commodities present are gold and iron, and the strategic and critical commodities copper and manganese. Some gold (deposit number Au 15) and manganese (Mn Fe 153) has been produced from mines located within the WSA.

Eight mineral occurrences are located within the Swansea (050-015A) WSA. With the exception of gold placers, all other deposits are associated with metamorphic core complexes. Commodities occurring include gold and iron, and the stretegic commodities manganese, silver, copper, fluorite and lead. Small production of silver, and possibly lead, gold and fluorite, was recorded by one mine within the WSA, while manganese was produced from another.

Two barite occurrences are located in the southern part of the Cactus Plain (050-014 A/B) WSA, in the northern extension of the Plomosa Mining District. Fluorite and copper (strategic commodities) staining are associated with barite. One deposit records minor production. 
No occurrences are located within the East Cactus Plain (050-017) WSA.

There has been much recent speculation about the potential for $0 i 1$ and gas occurrences in the Basin and Range of southern Arizona. It has been suggested that the Overthrust Belt, related to oil occurrences from Canada to Utah, extends into Arizona as a wide NW-SE trending belt curling around the Colorado Plateau in the Basin and Range area (Peirce, 1982; Anschutz, 1980). The theory states that around $60 \mathrm{~m} . y . B . P$. older crystalline rocks were thrust over younger, possibly oil-rich, strata (Peirce, 1982). The complex structures, including Basin and Range faults, found in southern Arizona coupled with the high temperatures created by igneous activity since that time dim the possibility of preservation of $0 i 1$ and gas. Peirce (1982) states if the Overthrust Belt exists, or ever has existed, in Arizona, geologic complexity obscures it and drilling has not yet resolved the issue. Anschutz (1980) suggests that the Overtrust Belt could become the most important oil and gas province to be discovered in the last 20 to 30 years, but also states that it is one of the most difficult and expensive areas to explore and develop. WSAs of the Bill Williams GRA are largely covered by oil and gas leases.

Silver, lead, copper, fluorite and manganese are the strategic commodities occurring within the WSAs and adjoining parts of the sub-areas. Much of the lead used in the United States is consumed in the manufacture of storage batteries and as a gasoline additive, al though use in gasoline is not as important as it once was. Use in ammunition and solder is also important, increasingly so during wartime. More silver is consumed in photography in the United States in one year than this country produces during that time (Brobst and Pratt, 1973). Although abundant elsewhere in the world, manganese, critical to the steel industry and also used in the chemical industry, is virtually absent in the United States. Copper, although 

considered a strategic and critical metal, occurs in abundance in Arizona. Fluorite is used as a flux in steel manufacture, with fluorine used also in aluminum smelting, refrigerants, solvents, and aerosol propellants.

In summary, it must be noted that the Bill Williams GRA contains a large number of mineral occurrences and many different commodities. Many deposits of stragegic and critical commodities, several of which have produced, are known to occur in the WSAs and surrounding parts of the sub-areas. Further exploration could lead to the discovery of potentially important deposits in the GRA and WSAs.

\section{THE GEOLOGY, ENERGY AND MINERAL RESOURCES \\ OF THE WILDERNESS STUDY AREAS}

In this section, each individual WSA is discussed with respect to its physiography, geology, mineral occurrences, resource potential, and recommendations for further work. For most of the WSAs, detailed and specific information is lacking; in these cases, information pertinent to the particular WSA will be summarized from the preceding sections. The classification of resource potential and level of confidence is according to the scheme provided by the Bureau of Land Management (attachment 9, dated March 24, 1982). The classification is summarized on the maps in figures 10 through 13 and detailed below.

\section{Classification Scheme}

1. The geologic environment and the inferred geologic processes do not indicate favorability for accumulation of mineral resources.

2. The geologic environment and the inferred geologic processes indicate low favorability for accumulation of mineral resources.

3. The geologic environment, the inferred geologic processes, and the reported mineral occurrences indicate moderate favorability for 
accumulation of mineral resources.

4. The geologic environment, the inferred geologic processes, the reported mineral occurrences, and the known mines or deposits indicate high favorability for accumulation of mineral resources.

\section{Level of Confidence Scheme}

A. The available data are either insufficient and/or cannot be considered as direct evidence to support or refute the possible existence of mineral resources within the respective area.

B. The available data provide indirect evidence to support or refute the possible existence of mineral resources.

C. The available data provide direct evidence to support or refute the possible existence of mineral resources.

D. The available data provide abundant direct and indirect evidence to support or refute the possible existence of mineral resources.

\section{The Needles Eastern Addition (050-005B)}

\section{Physiography}

The WSA lies at the northern end of the Mohave Mountains, on the eastern boundary of the Lake Havasu National Wildlife Refuge. The topography is hilly with a maximum relief of about 600 feet.

\section{Geology}

The northern two-thirds of the WSA is underlain by Precambrian gneiss, and the southern third by Tertiary andesitic rocks. There is no detailed information about these rocks at this location. Elsewhere in western Arizona the metamorphic rocks consist of quartzofeldspathic biotite-muscovite gneiss which may be metavolcanic (Stensrud and More, 1980). The andesitic rocks rest unconformably on the gneiss and probably consist of flows and tuffs. 


\section{Mineral Deposits}

No mineral deposits are known to occur within the WSA. Three occurrences with no production and unspecified commodity lie near the WSA. In other parts of the Mohave Mountains there are Mn occurrences associated with volcanics and with minor production; vein Au-W occurrences with minor production; and placer gold deposits with 100 to $1000 \mathrm{oz}$. Au production. In the Hualapai Mountains to the northeast, massive sulfide deposits are associated with Precambrian gneisses.

\section{Land Classification for GEM Resources Potential}

Metallic Minerals. The WSA (area 1; fig. 10) is classified as having

low favorability for the occurrence of metallic mineral deposits at a confidence level of $B$. the reasons for the above classification are as follows:

A. No mineral occurrences are known within the WSA. On the other hand,

B. elsewhere in the Mohave Mountains there are Mn occurrences associated with Mid-Tertiary volcanics, Au-W lodes cutting gneiss, and Au placers.

c. Massive sulfide deposits are found in similar rock types in the Hualapai Mountains to the northeast.

\section{Other Resources}

The WSA is not favorable for the occurrence of other resources at a confidence level of $B$, because there are no indications suggesting their presence. 




\section{Recommendations}

For area 1 it is recommended that:

A. The three occurrences with unspecified commodities be field checked to establish the nature of the mineralization, and

B. the gneisses should be field checked to determine whether they are rhyolitic metavolcanics and thus possible host rocks for massive sulfide deposits.

\section{The Gibraltar Mountain WSA (050-012)}

\section{Physiography}

The WSA lies within the Buckskin Mountains, east of the Colorado River. The mountains are moderately steep and have a maximum relief of about 1500 feet. The topography generally slopes south and east towards Osborne Wash.

\section{Geology}

The WSA is underlain by Precambrian gneiss, Paleozoic sediments, Tertiary sediments, and Tertiary intrusives which are in the upper plate of a metamorphic core complex, which in turn is overlain by Quaternary to Tertiary basalt.

The Precambrian rocks crop out in the northwest of the WSA and have been described by Davis et al. (1980). They consist of metasedimentary and minor felsic metavolcanic quartzofeldspathic gneiss, orthogneiss of granodiorite to granite composition, amphibolite, and granite porphyry and diabase which intrude the above metamorphic rocks. The metamorphic rocks are in the sillimanite zone of the amphibolite facies. The granite porphyry intrusives are similar to potassic 1.5-1.4 b.y.B.P. granites present elsewhere in southwestern Arizona.

Paleozoic rocks crop out along the northwest margin of the WSA and have 

been described by Davis et al. (1980). They consist of marble, quartzite and phyllite that may possibly be correlative of the Kaibab Limestone, Coconino Sandstone and Bright Angel Shale. They are foliated and have been metamorphosed to the greenschist facies. They rest unconformably on, and are in fault contact with the Precambrian gneisses.

The Tertiary sediments crop out near the northern, central and southeastern part of the WSA. They have been described in the Buckskin and Rawhide Mountains by Davis et al. (1980) where they consist of the Gene Canyon and Copper Basin formations. The Gene Canyon Formation consists of red to buff sandstone, andesite, debris flows, siltstone and freshwater limestone. It is up to 2000 feet thick and is 01 igocene to Mid-Miocene in age. The Copper Basin Formation consists of red sandstone, conglomerate and siltstone interbedded wtih andesitic rocks. It is up to 2500 feet thick and was deposited 19-21 m.y.B.P. It rests unconformably on the Gene Canyon Formation. Both Tertiary formtions are partly allochthonous and in part rest unconformably on upper plate rocks.

A Tertiary intrusive of unknown composition is located near the center of the WSA. Over most of the WSA the older rocks are capped by a basalt.

\section{Mineral Deposits}

Epigenetic mineral deposits within or near the WSA lie along faults in Precambrian metamorphic rocks and Paleozoic limestone, and along faults separating the two. The deposits contain $\mathrm{Au}+\mathrm{Cu}, \mathrm{Ag}$ and $\mathrm{Fe}$. All the host rocks are in the upper plate of a metamorphic core complex, which lies below a younger unmineralized basalt. The faults along which the mineralization occurs may be listric normal faults associated with late stages of metamorphic core complex emplacement. The deposits typically contain cuprite, chrysocolla, malachite and hematite. They were formed under an 


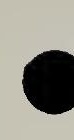

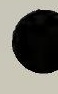

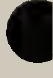


oxidizing environment and at depth may give way to more reducing, sulfide-bearing mineralogies. Seven such deposits are present within the WSA and three of these have had significant production as follows: Cu $24-8000$ tons; $\mathrm{Cu} 25$ - 800 tons; and $\mathrm{Ag} \mathrm{Cu} \mathrm{Au} 103$ - 170 tons. Two deposits just outside the WSA boundary have also had significant production; Au 3 produced $10,000 \mathrm{Oz}$. of $\mathrm{Au}$ and $\mathrm{Cu} 27$ produced 3000 tons of ore.

One placer $\mathrm{Au}$ deposit (Au 100) with minor production is located within the WSA.

\section{Land Classification for GEM Resources Potential}

Metallic Minerals. Parts of the WSA where Precambrian metamorphic rocks, Paleozoic metasedimentary rocks, and Tertiary sediments are exposed (area 2; fig. 11) are considered to be highly favorable at a confidence level of $\mathrm{C}$. The reasons for the above classification are as follows:

A. Several mines with significant production are present within the area and nearby just outside the WSA.

B. Listric normal faults mapped in the Whipple Mountains in California, probably extend southeastwards into the WSA.

C. The area is probably underlain by a dislocation surface which may be a favorable site for mineral deposition.

The remainder of the WSA where upper plate rocks are covered by basalt (area 3; fig. 11) are classified as having low favorability for the occurrence of metalic minerals at a confidence level of $B$. The reasons for this classification are as follows:

A. The underlying upper plate rocks of the metamorphic core complex are as favorable as the rocks in area 1, but

B. the upper plate rocks are covered with an unknown thickness of barren basalt. 



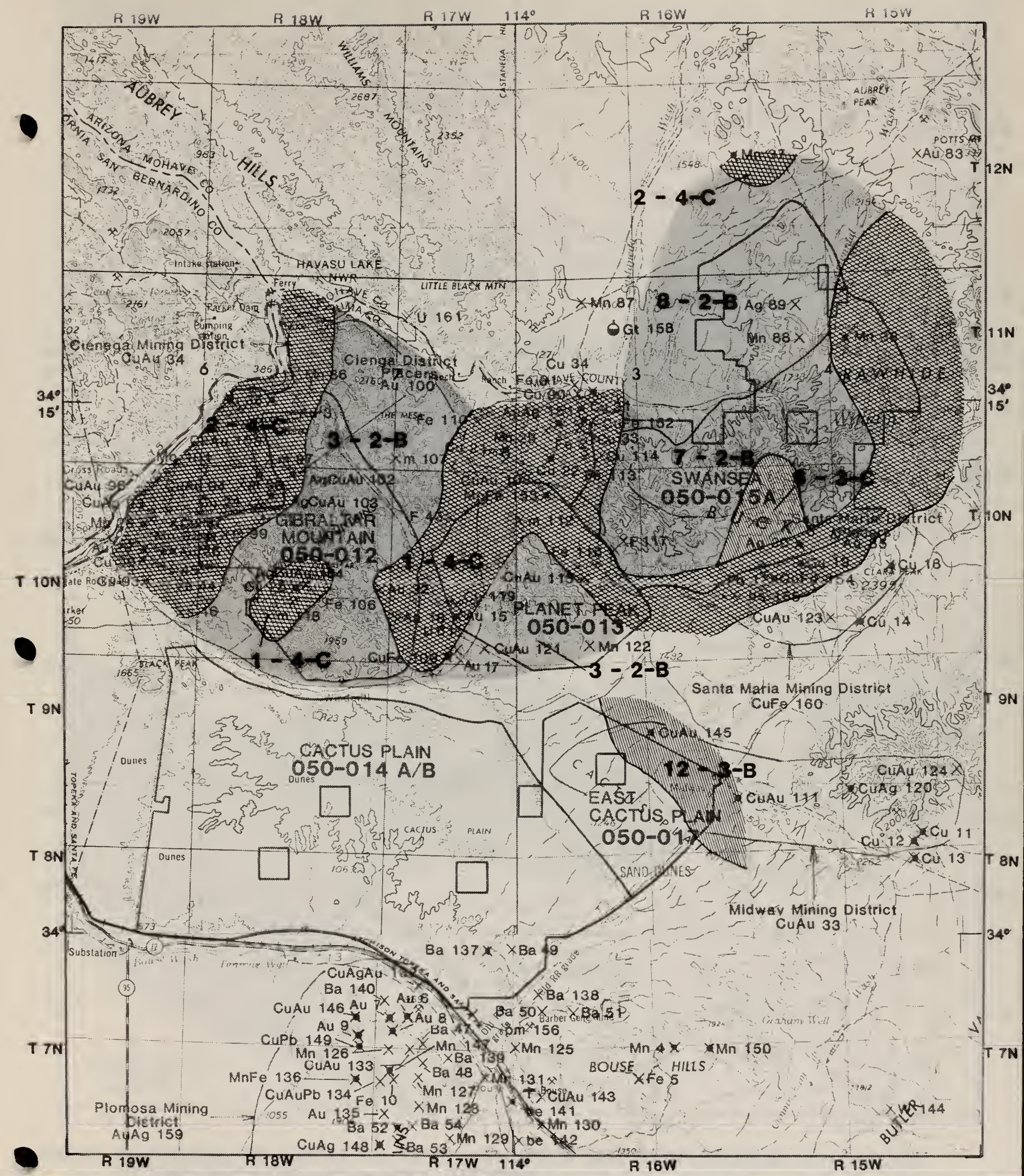

FIG1 1 FAVORABILITY AND LEVEL OF CONFIDENCE MAP FOR METALLIC MINERAL RESOURCES OF THE BUCKSKIN SUB-AREA, ARIZONA 


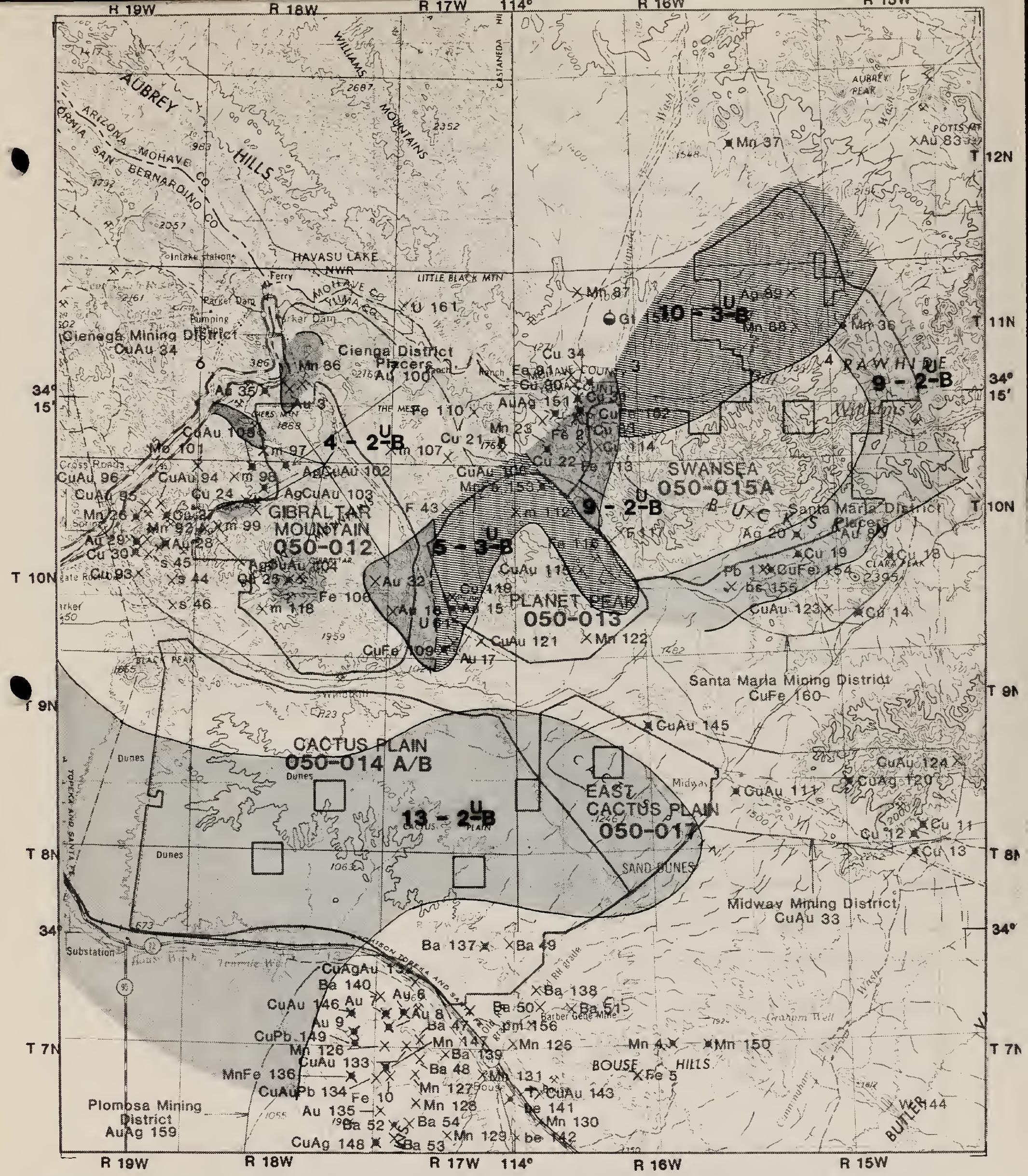


.

C

0 
Uranium. Parts of the WSA where Tertiary sediments are exposed (area 4; fig. 12) are considered to have a low favorability for the occurrences of uranium at a confidence level of $B$. The reasons for this classification are as follows:

A. No uranium occurrences are known in the area, however,

B. Adequate source rocks and aquifers are present within the sediments.

C. Suitable reductants may be present where the Tertiary sediments are faulted against Paleozoic Shale.

D. Uranium occurrences along a dislocation surface (U 61) and within Tertiary sediments (U 61A) are present outside the WSA.

Other Resources. The WSA is not favorable for the occurrence of other resources at a confidence level of $B$, because there are no indications suggesting their presence or, as in the case of saleable resources, there are few nearby markets.

\section{Recommendations}

For area 2 it is recommended that:

A. The area be field checked in order to determine whether the mineralization is supergene and if so, assess prospects for primary ore at depth.

B. Determine depth to dislocation surface by seismic refraction.

C. Mineralized fracture zones should be analysed for $\mathrm{Cu}, \mathrm{Au}, \mathrm{Ag}, \mathrm{Zn}$, Fe, $\mathrm{V}, \mathrm{Li}, \mathrm{Cr}, \mathrm{U}$ and $\mathrm{Th}$ to determine whether concentrations are anomalous.

For area 3 it is recommended that:

A. The area be field checked to determine the thickness of basalt that overlies the upper plate rocks. 
- 
For area 4 it is recommended that the area be field checked to determine whether suitable reductants for uranium are present.

\section{The Planet Peak WSA (050-013)}

\section{Physiography}

The WSA lies within the Buckskin Mountains. The topography is mountainous and steep and the area has a maximum relief of 1500 feet. The topography generally slopes outward from the center of the WSA.

\section{$\underline{\text { Geology }}$}

The WSA is underlain by metamorphic core rocks and Paleozoic and Tertiary sediments. The sedimentary rocks are separated from the metamorphic core by a dislocation surface which is exposed in the northwest and northeast ends of the WSA.

The metamorphic core rocks comprise the lower plate of the metamorphic core complex and have been described by Davis et al. (1980) and Shackelford (1977). They consist of quartzofeldspathic gneiss, granitic gneiss and amphibolite which are intruded by foliated hornblende-biotite quartz diorite, garnet-biotite granodiorite and two-mica adamellite. At structurally higher levels these metamorphic and igneous rocks become progressively mylonitized and deformation becomes progressively brittle, and the mylonite grades upward into a chloritic breccia. The brecciation penetrates up to 1000 feet into the lower plate. The mylonitic foliation defines an east-northeast striking gently dipping fold which in the WSA also plunges gently to the south (Rehrig and Reynolds, 1980).

The Paleozoic and Tertiary sedimentary rocks crop out in the northwest and northeast parts of the WSA. They have been described in the section on the Gibraltar Mountain WSA. 


\section{Mineral Deposits}

Five mineral occurrences are located within or close to the WSA. Four

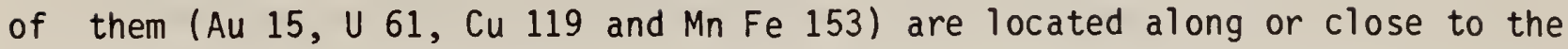
dislocation surface. The remaining two (Fe 116 and $\mathrm{Mn} 122$ ) are within the metamorphic core. Au 15 and Fe Mn 153 contain mineral assemblages formed under oxidizing conditions and at depth could give way to more reducing sulfide-bearing assemblages. Several tens of tons of ore have been produced from occurrence Au 15.

\section{Land Classification for GEM Resources Potential}

Metallic Minerals. The parts of the WSA underlain by the upper plate of the metamorphic core complex and the dislocation surface (area 2;

fig. 11) are classified as highly favorable for occurrence of metallic minerals at a confidence level of $C$. The reasons for this classification are as follows:

A. Several prospects, one of them with minor production occur within the area.

B. The area is underlain by the dislocation surface which may be a favorable site for mineral deposition (see Keith and Reynolds, $1980)$.

The remainder of the WSA (area 3 ) which is underlain by the metamorphic core has low favorability for occurrence of metallic minerals at a confidence level of $B$. The reasons for this classification are:

A. Two minor occurrences are present in the area.

B. Most mineral deposits associated with metamorphic core complexes are located near the dislocation $\mathrm{plane}$ and in the nearby upper plate rather than in the metamorphic core itself.

Uranium. The parts of the WSA underlain by the upper plate of the 
metamorphic core complex and the dislocation surface (area 5; fig. 12), are considered to have moderate favorability for uranium, at a confidence level of $B$. The reasons for this classification are as follows:

A. One uranium occurrence $(U 61)$ is located along or near a dislocation surface.

B. Keith and Reynolds (1980) have shown that $U$ is concentrated in chloritic breccia below the dislocation surface.

C. Tertiary sediments are present in the upper plate, and these contain good source rocks for uranium, aquifers and possible reductants.

\section{Recormendations}

For areas 2 and 5 (co-extensive areas) it is recommended that the areas should be field checked to determine whether the mineralization is supergene and if so assess prospects for ore at depth.

For areas 2, 3 and 5, the dislocation zone, the chloritic breccia and other fractured zones should be analysed for $\mathrm{Cu}, \mathrm{Au}, \mathrm{Ag}, \mathrm{Zn}, \mathrm{Fe}, \mathrm{V}, \mathrm{Li}, \mathrm{Cr}, \mathrm{U}$ and Th to determine whether enrichment in these elements is widespread (see Keith and Reynolds, 1980).

\section{The Swansea WSA (050-015A)}

\section{Physiography}

The WSA lies within the Buckskin and Rawhide Mountains. The topography is hilly and the area has a relief of generaliy less than 1000 feet. The Bill Williams River flows across the WSA from east to west. In the south the topography slopes towards the Cactus Plain and in the north and west toward Centennial Wash. 
0

0

0 


\section{Geology}

The WSA is underlain by metamorphic core rocks; by Precambrian gneiss, Paleozoic sediments, Tertiary sediments and Tertiary intrusives separated from the metamorphic core by a dislocation surface; and by post-metamorphic core complex sediments and volcanics. The dislocation surface lies near the southwestern, southern and western boundaries of the WSA and may underlie younger rocks near the northern and northwestern boundary. The post-metamorphic core complex rocks lie largely in the north and northwestern part of the WSA.

The metamorphic cores, together with their mylonitic gneisses, of the lower plate; and the Precambrian gneiss, Paleozoic sediments, Tertiary sediments and Tertiary intrusive of the upper plate, have been described in earlier sections on the Gibraltar Mountain and Planet Peak WSAs. The descriptions will not be repeated here.

The rocks that post-date metamorphic core complex emplacement inciude basalt, silicic volcanics and Late Tertiary to Quaternary sediments. The volcanics form a bimodal suite probably associated with Basin and Range faulting. The silicic volcanics lie along the "Aubrey Lineament" approximately marking the northeasterly margin of metamorphic core complexes. The silicic volcanics may possibly be correlated with the garnet-and topaz-bearing rhyolites described by Burt et al. (1981) from Burro Creek, near the Anderson Mine, east of the Buckskin sub-area. These rhyolites are enriched in $F, B e, L i, R b, S n$ and possibly $U$ and could be good source rocks for U. The silicic volcanics are interbedded with and overlie red arkosic conglomerates (Suneson and Lucchita, 1979), sandstones and siltstones of fluvial and lacustrine origin (Scarborough and Wilt, 1979). 



\section{Mineral Deposits}

Eight mineral occurrences are located within the WSA ( $\mathrm{Ag} 20, \mathrm{Mn} 36$, Au 85, Mn 88, Ag 89, Cu 114, Fe 116 and F 117) and an additional eight lie close to the western and southern boundaries.

Two of the deposits lie within the metamorphic core (Fe 116 and $F 117$ ). Nothing is known about them but neither has any recorded production.

Seven deposits lie at or very close to the dislocation surface between metamorphic core and upper plate Precambrian gneiss, Paleozoic limestone or Tertiary sediment (Pb 1, Cu 19, Ag 20, Mn 36, Cu 114, Cu Fe 152, Cu Fe 154). These deposits contain psilomelane, pyrolusite, hematite, oxidized copper minerals, and locally, chalcopyrite, bornite and pyrite. They have a total production of over 350,000 tons (mainly from $\mathrm{Cu} 19$ which is just outside the WSA boundary) and range in grade from $2-3 \% \mathrm{Cu}$ and up to $0.4 \mathrm{oz}$. Au.

Four deposits ( $\mathrm{Cu} 31, \mathrm{Cu} 33, \mathrm{Fe} 113$ and $\mathrm{Au} \mathrm{Ag} \mathrm{151)} \mathrm{occur} \mathrm{along} \mathrm{faults} \mathrm{in}$ upper plate Precambrian gneiss and Paleozoic sediments. The deposits contain hematite, oxidized copper minerals and bornite, chalcopyrite and pyrite. Production from these deposits has been over 66,000 tons (mainly from Cu 31, just outside the WSA boundary), ranging in grade from $3-10 \% \mathrm{Cu}$ and 0.4 to 1.0 oz. Au.

Little is known about the remaining deposits (Mn 88, Ag 89) but there has been no production and they are probably associated with post-metamorphic core complex volcanism.

The Santa Maria Placers (Au 85) lie in the south central part of the WSA. A total of $120 \mathrm{oz}$. of Au has been produced from this area.

\section{Land Classification for GEM Resources Potential}

Metallic Minerals. The parts of the WSA underlain by exposed upper plate Precambrian, Paleozoic and Tertiary rocks and the dislocation surface 
1 
(area 2; fig. 11) are considered to be highly favorable for metallic deposits at a confidence level of $C$. The reasons for this classification are as follows:

A. Several mines with significant copper and gold production are located in this environment.

B. The area is underlain by a dislocation surface, which, according to Keith and Reynolds (1980), may be a favorable site for mineral deposition.

The part of the WSA in the vicinity of the Santa Maria District placers (Au 85, area 6; fig. 11) is considered moderately favorable for metallic minerals at a confidence level of $C$. The reason for this classification is that about $120 \mathrm{oz}$. of $\mathrm{Au}$ have been produced from this area.

Other parts of the WSA where the metamorphic core is exposed (area 7; fig. 11) have a low favorability for the occurrence of metallic mineral deposits at a confidence level of $B$. The reasons for this classification are:

A. There are no metallic occurrences present in the area.

B. Most mineral deposits associated with metamorphic core complexes are located near the dislocation plane and in the nearby upper plate rather than in the metamorphic core itself, however,

C. in the nearby metamorphic cores some mineralization does occur along shears.

The remainder of the WSA which is underlain by post-metamorphic core complex rocks (area 8; fig. 11 ) is considered to have low favorability for metallic ore deposits at a confidence level of $B$. The reasons for this classification are as follows:

A. The manganese occurrence ( $M n$ 88) has no reported production, occurs within Quaternary to Tertiary basalts and is unlikely to be of any 


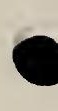

0

0 
economic importance.

B. The sitver occurrence ( $\mathrm{Ag} 89$ ) has no reported production, occurs in Quaternary to Late Tertiary sediments, and is probably uni ikely to be of great economic importance.

Uranium. The parts of the WSA underlain by the upper plate of the metamorphic core complex and the dislocation surface (area 9; fig. 12) are considered to have low favorability for uranium at a confidence level of $B$. The reasons for this classification are as follows:

A. There are no uranium occurrences in the area, but

B. Keith and Reynolds (1980) have shown that $U$ is concentrated in chloritic breccia below the dislocation surface, and

C. Tertiary sediments are present in the upper plate. These contain good source rocks for uranium, aquifers, and possibly reductants.

The part of the WSA underlain by post-metamorphic core complex volcanic and sedimentary rocks (area 10; fig. 12) is moderately favorable for uranium deposits at a confidence level of $B$. The reasons for this classification are as follows:

A. There are no known uranium occurrences in this area, but,

B. probably excellent source rocks in the form of silicic volcanics are present in the area.

C. Aquifers are interbedded and underlie volcanics.

D. Geothermal waters probably present in the area may act as suitable reductants.

Non-Metallic Minerals. The area near the fluorite occurrence (F 117, area 11; fig. 13) is considered to have low favorability for non-metallic minerals at a confidence level of $B$. The reasons for this classifiction are as follows: 
•

-

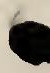



- 
A. The occurrence has no reported production.

B. No other fluorite occurrences are known in the area.

\section{Recommendations}

For area 2 it is recommended that the area be field checked to determine whether supergene processes were important and if so to assess the prospects for primary ore at depth.

For areas 2, 5 and 9 it is recommended that the dislocation surface and the underlying chloritic breccia should be analysed for $\mathrm{Cu}, \mathrm{Au}, \mathrm{Ag}, \mathrm{Zn}, \mathrm{Fe}$, $V, L i, C r, U$ and $T h$ to determine whether enrichment in these elements has taken place.

For area 6 it is recommended that it be field checked to determine the extent of alluvium that could be gold-bearing.

For areas 8 and 10 it is recommended that:

A. The area be field checked for suitable source rocks for stratabound $U$ and/or $\mathrm{Ag}$ deposits, suitable aquifers for their transport, and suitable reductants.

B. All well waters should be analysed for uranium, silver, Eh, $\mathrm{pH}$, chloride, carbonate, phosphate, calcium and vanadium. the solubility index for several uranium and silver species should then be calculated.

\section{The Cactus Plain (050-014 A/B) and}

East Cactus Plain (050-017 WSAs

\section{Physiography}

The WSAs occupy the central position of the Cactus Plain, a surface which slopes gently towards the west. It is extensively covered with sand dunes. 
$\bullet$

$\bullet$ 


\section{Geology}

The WSAs are largely covered by Quaternary alluvium and active dunes. Small areas of outcrops are present in the northwest, northeast and south-central parts of the WSAs.

Metamorphic core rocks, part of the Harcuvar metamorphic core complex, crop out in the northeast. Tertiary and Quaternary-Tertiary basalts crop out in the northwest and minor Tertiary sediments and andesitic volcanics crop out in the south-central region. These rock types have been described in earlier sections and the descriptions will not be repeated here. The Cactus Plain is also probably underlain by thick (up to 3200 feet in the southwest) sequences of mid- and late Tertiary sediments, as suggested by depth to basement estimates of Oppenheimer and Sumner (1981).

\section{Mineral Deposits}

Two barite occurrences are located in the southern part of the WSAs. They are the northernmost extension of outcrops of the Plomosa Mining District. There has been minor production reported from $\mathrm{Ba} 137$ which consists of barite-fluorite veins with copper staining in a fractured Tertiary agglomerate and tuff. In the northeast, just outside the WSA boundaries are two $\mathrm{Cu} \mathrm{Au} \mathrm{Ag}$ occurrences (111 and 145) in metamorphic core complex gneiss and calcareous schist. Production has been somewhat more than 200 tons of $1.3 \% \mathrm{Cu}, 0.2 \mathrm{oz}$. Au and $0.1 \mathrm{oz}$. Ag. The ore contains oxidized copper minerals.

\section{Land Classification for GEM Resources Potential}

Metallic Minerals. The northeastern part of the WSAs where metamorphic core rocks crop out (area 12; fig. 11) is classified as having moderate favorability for metallic mineral deposits at a confidence level of 

B. The reasons for this classification are:

A. Two Cu-Au occurrences with minor production are located just beyond the WSA boundary.

B. The occurrences are within a metamorphic core showing schistosity, which could be mylonitic foliation below the dislocation surface. As such it would be a favorable location for metallic deposits. The remaining part of the WSAs are not favorable for metallic minerals.

Uranium. The part of the WSAs where there is a thick accumulation of Tertiary sediments (area 13; fig. 12) is considered to have a low favorability for uranium deposits at a confidence level of $B$. The reasons for this classification are as follows:

A. There are no uranium occurrences, but

B. within the Cactus Plain basin there is a thick accumulation of sediments and volcanics which may be favorable hosts for stratiform uranium deposits.

Mon-Metallic Minerals. The southernmost part of the WSAs (area 14; fig. 13$)$ is classified as moderately favorable for barite-fluorite mineralization at a confidence level of $B$. The reasons for this classification are:

A. Two minor barite-fluorite occurrences with minor production are present in the area.

B. The area is just to the north of the Plomosa Mining District where numerous mines are located.

C. The occurrences are in poorly consolidated sedimentary rocks and could be extensive. 


\section{Recommendations}

For area 12 it is recommended that the area be examined in the field to determine whether the structurally highest part of the metamorphic core (the chloritic breccia) is exposed.

For area 13 it is recommended that:

A. The area be field checked to determine whether suitable source rocks, aquifer and reductants are present for uranium transport and deposition.

B. All well waters should be analysed for uranium, Eh, $\mathrm{pH}$, carbonate, phosphate, calcium and vanadium. The solubility index for several uranium species should be calculated.

For area 14 it is recommended that the area be examined in the field to determine whether the barite-fluorite mineralization is strataform, in which case it could be of considerable extent. 
6

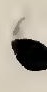




\section{REFERENCES}

Anderson, C.A., and Silver, L.T., 1976, Yavapai Series - a greenstone belt, in Wilt, J.C., and Jenney, J.P., eds., Tectonic Digest: Arizona Geological Society Digest, v. 10, p. 13-26.

Anderson, P., 1976, Proterozoic convergent plate tectonics (abstract): Twenty-fifth International Geologic Congress, v. 1, p. 73.

Anderson, P., and Guilbert, J.M., 1979, The Precambrian massive sulfide deposits of Arizona - A distinct metallogenic epoch and province, in Ridge, J.D., ed., Papers on mineral deposits of western North America: Nevada Bureau of Mines and Geology, Report 33, p. 39-48.

Anschutz, P.F., 1980, The overthrust belt: Will it double U.S. gas reserves?: World 0il, January 1980, p. 111-116.

Arizona Bureau of Mines, 1969, Mineral and water resources of Arizona: Arizona Bureau of Mines Bulletin 180, 638 p.

Burchfiel, B.C., 1979, Geologic history of the central western United States, in Ridge, J.D., ed., Papers on mineral deposits of western North America: Nevada Bureau of Mines and Geology Report 33, p. 1-12.

Burnham, W.C., 1981, Physicochemical constraints on porphyry mineralization, in Dickinson, W.R., and Payne, W.D., Relations of tectonics to ore deposits in the southern Cordillera: Arizona Geological Society Digest, v. 14, p. $71-77$.

Burt, D.M., Monger, J.C., and Christiansen, E.H., 1981, Garnet and topaz-bearing rhyolites from near Burro Creek, Mohave County, western Arizona - Possible exploration significance: Arizona Geological Society Digest, v. $13, p .1-4$.

Chappe11, B.W., and White, A.J.R., 1974, Two contrasting granite types: Pacific Geology, no. 8, p. 173-174.

Clark, K.F., Foster, C.T., and Damon, P.E., 1982, Cenozoic mineral deposits and subduction related magmatic arcs in Mexico: Geological Society of America Bulletin, v. 93, p. 533-544.

Coney, P.J., 1980, Cordilleran metamorphic core complexes: An overview: Geological Society of America Memoir 153, p. 7-31.

Coney, P.J., and Reynolds, S.J., 1980, Cordilleran metamorphic core complexes and their uranium favorability: U.S. Department of Energy Open-File Report GJBX-258(80).

Coney, P.J., and Reynolds, S.J., 1977, Cordilleran benioff zones: Nature, v. 270 , p. 403-406.

Damon, P.E., 1968, Application of the potassium-argon method to the dating of igneous and metamorphic rocks within the basin ranges of the southwest, in Titley, S.R., ed., Southern Arizona guidebook III: Arizona Geological Society, p. 7-20. 

Damon, P.E., and Mauger, R.L., 1966, Epeirogeny - orogeny viewed from the Basin and Range province: Transactions of the American Institute of Mining, Metallurgical and Petroleum Engineers v. 235, p. 99-112.

Damon, P.E., Shafiqullah, M., and Clark, K.F., 1981, Age trends of igneous activity in relation to metallogenesis in the southern Cordillera, in Dickinson, W.R., and Payne, W.D., eds., Relations of tectonics to ore deposits in the southern Cordillera: Arizona Geological Society Digest, v. 12, p. $137-154$.

Davis, G.H., 1981, Regional strain analysis of the superposed deformations in southeastern Arizona and the eastern Great Basin, in Dickinson, W.R., and Payne, W.D., eds., Relations of tectonics to ore deposits in the southern Cordillera: Arizona Geological Society Digest, v. 14, $p$. $155-172$.

Davis, G.H., 1980, Structural characteristics of metamorphic core complexes, southern Arizona, in Crittenden, M.D. Jr., Coney, P.J., and Davis, G.H., eds., Cordilleran metamorphic core complexes: Geological Society of America Memoir 153, p. 35-77.

Davis, G.H., and Coney, P.J., 1979, Geologic development of Cordilleran metamorphic core complexes: Geology, v. 7, p. 120-124.

Davis, G.A., Anderson, J.L., Frost, E.G., and Shackelford, T.J., 1980, Mylonitization and detachment faulting in the Whipple - Buckskin Rawhide Mountains terrane, southeastern California and western Arizona: Geological Society of America Memoir 153, p. 79-129.

Dickinson, W.R., 1981, Plate tectonic evolution of the southern Cordillera, in Dickinson, W.R., and Payne, W.D., eds., Relations of tectonics to ore deposits in the Southern Cordillera: Arizona Geological Society Digest, v. 14, p. 113-135.

Donnelly, M.E., and Hahn, G.A., 1981, A review of the Precambrian volcanogenic massive sulfide deposits in central Arizona and the relationship to their depositional environment, in Dickinson, W.R., and Payne, W.D., eds., Relations of tectonics to ore deposits in the southern Cordillera: Arizona Geological Society Digest, v. 14, $p$. $11-22$.

Eberly, L.D., and Stanley, T.B. Jr., 1978, Cenozoic stratigraphy and geologic history of southwestern Arizona: Geological Society of America Bulletin, v. 89 , p. 921-940.

Elston, W.E., 1978, Mid-Tertiary cauldrons and their relationship to mineral resources, southwestern New Mexico: A brief review: New Mexico Geological Society Special Publication 7, p. 107-113.

Elston, W.E., and Bornhorst, T.J., 1979, The Rio Grande rift in context of regional post-40 m.y. volcanic and tectonic events, in Reicker, R.E., ed., Rio Grande rift: Tectonics and magmatism: American Geophysical Union, p. 416-438. 

Fenneman, H.M., 1931, Physiography of western United States: New York, McGraw-Hi11, 534 p.

Harding, L.E., 1980, Petrology and tectonic setting of the Livingston Hills Formation, Yuma County, Arizona: Arizona Geological Society Digest, $v$. 12 , p. $135-145$.

Heidrick, T.L., and Titley, S.R., 1982, Fracture and dike patterns in Laramide plutons and their structural and tectonic implications, in Titley, S.R., ed., Advances in geology of the porphyry copper deposits: The University of Arizona Press, Tuscon, Arizona, p. 73-91.

Heindl, L.A., and Lance, J.F., 1960, Topographic, physiographic and structural subdivisions of Arizona: Arizona Geological Society Digest, v. 3, p. 12-18.

Heind1, L.A., and McClymonds, N.E., 1964, Younger Precambrian formations and the Bolsa Quartzite of Cambrian age, Papago Indian Reservation, Arizona: U.S. Geological Survey Professional Paper 501-C, p. C43-C49.

Johnson, M.G., 1972, Placer gold deposits of Arizona: U.S. Geological Survey Bulletin 1355, 103 p.

Jones, N.0., 1979, Geothermal resources - what to look for in Arizona: Arizona Bureau of Geology and Mineral Technology Fieldnotes, v. 9, no. 3 , p. $12-13$.

Keith, S.B., 1981, The great southwestern Arizona overthrust oil and gas play: Arizona Bureau of Geology and Mineral Technology Fieldnotes, $v$. 11 , no. 1 , p. 1 .

Keith, S.B., 1980, The great southwestern Arizona overthrust oil and gas play: Arizona Bureau of Geology and Mineral Technology Fieldnotes, $v$. 10, no. 1, pp.1-3, 6-8.

Keith, S.B., 1978, Index of mining properties in Yuma County, Arizona: Arizona Bureau of Geology and Mineral Technology Bulletin 192, $185 \mathrm{p}$.

Keith, S.B., and Reynolds, S.J., 1980, Geochemistry of Cordilleran metamorphic core complexes, in Coney, P.J., and Reynolds, S.J., eds., Cordilleran metamorphic core complexes and their uranium favorability:

U.S. Department of Energy Open-File Report GJBX-258(80), p. 247-303.

La Point, D.J., 1974a, Possible source areas for sandstone copper deposits in northern New Mexico: New Mexico Geological Society, twenty-fifth Field Conference, p. 305-308.

La Point, D.J., 1974b, Genesis of sandstone-type copper deposits at the Scholle district, central New Mexico (abstract): Geological Society of America, Abstracts with Programs, v. 6, p. 451-452.

Lowe11, J.D., 1974, Regional characteristics of porphyry copper deposits of the southwest: Economic Geology, v. 69, p. 601-617. 

McCrory, F.J., and O'Haire, R.T., 1965, Map of known mon-metallic mineral occurrences of Arizona: Arizona Bureau of Mines, scale 1:1,000,000.

Metzger, D.G., 1968, The Bouse Formation (Pliocene) of the Parker - Cibola area, Arizona and Cal ifornia: U.S. Geological Survey Professional Paper 600-D, P.D126-D136.

Metzger, D.G., 1967, Parker - Blythe - Cibola area, in Mckee, E.D., Wilson, R.F., Breed, J.B., and Breed, C.S., eds., Evolution of the Colorado River in Arizona: Museum of Northern Arizona, Bulletin 44, p. 2-3.

Miller, F.K., 1970, Geologic map of the Quartzite quadrangle, Yuma County, Arizona: U.S. Geological Survey Map GQ 841, scale 1:62,500.

Nielsen, R.L., 1979, Regional tectonics and the emplacement of Laramide porphyry-copper intrustions - Arizona - New Mexico, in Ridge, J.D., ed., Papers on mineral deposits of western North America: Nevada Bureau of Mines and Geology Report 33, p. 49-56.

Oppenheimer, J.M., and Sumner, J.S., 1981, Gravity modelling of the basins in the Basin and Range province, Arizona: Arizona Geological Society Digest, v. 13, p. 111-116.

Peirce, H.W., 1982, The search for petroleum in Arizona: Arizona Bureau of Geology and Mineral Technology Fieldnotes, v. 12, no. 2, p. 1-5.

Peirce, H.W., 1979, Land: Arizona Bureau of Geology and Mineral Technology Fieldnotes, v. 9, no. 3, pp. 4-7, 13.

Rehrig, W.A., and Heidrick, T.L., 1976, Regional tectonic stress during the Laramide and Late Tertiary intrusive periods, Basin and Range province, Arizona in Wilt, J.C., and Jenney, J.P., eds., Tectonic Digest: Arizona GeologicaT Society Digest v. 10, p. 205-228.

Rehrig, W.A., and Reynolds, S.J., 1980, Geologic and geochronologic reconnaissance of a northwest-trending zone of metamorphic core complexes in southern and western Arizona: Geologic Society of America Memoir 153, p. 131-157.

Reynolds, S.J., 1980, A conceptual basis for the occurrence of uranium in cordilleran metamorphic core complexes, in Coney, P.J., and Reynolds, S.J., Cordilleran metamorphic core complexesand their uranium favorability: U.S. Department of Energy Open-File Report GJBX-258(80), p. 187-246.

Reynolds, S.J., 1980, Geologic framework of west-central Arizona, in Jenney, J.P. and Stone, C., eds., Studies in western Arizona: - Arizona Geological Society Digest v. 12, p. 1-16.

Robison, B.A., 1980, Description and analysis of Mesozoic "Red Beds", western Arizona and southeastern California: Arizona Geological Society Digest, v. 12 , p. 147-154.

Scarborough, R.B., 1979, Cenozoic history and uranium: Arizona Bureau of Geologic and Mineral Technology Fieldnotes, v. 9, no. 3, pp. 1-3, 14-16. 

Scarborough, R.B., and Wilt, J.C., 1979, A study of uranium favorability of Cenozoic sedimentary rocks, Basin and Range province, Arizona. Part I, general geology and chronology of pre-Miocene Cenozoic sedimentary rocks: The University of Arizona and the U.S. Geological Survey Open File-Report 79-1429.

Schmitt, H.A., 1966, The porphyry copper deposits in their regional setting, in Titley, S.R., and Hicks, C.L., eds., Geology of the porphyry copper deposits, southwestern North America: Tucson, University of Arizona Press, p.17-33.

Shafiqullah, M., Damon, P.E., Lynch, D.J., Reynolds, S.J., Rehrig, W.A., and Raymond, R.H., 1980, K-Ar geochronology and geologic history of southwestern Arizona and adjacent areas: Arizona Geological Society Digest, v. 12, p. 201-260.

Sherborne, J.E., Buckovic, W.A., Dewitt, D.B., Hellinger, T.S., Pavlak, S.J., 1979, Major uranium discovery in volcaniclastic sediments, Basin and Range province, Yavapai County, Arizona: American Association of Petroleum Geologists Bulletin, v. 63, p. 621-646.

Silver, L.T., 1978, Precambrian formation and Precambrian history in Cochise County, southeastern Arizona, in Callender, J.F, Wilt, J.C., and Clemons, R.E., eds., Land of Cochise: New Mexico Geological Society Guidebook, 29 Field Conference, Socorro, p. 157-163.

Silver, L.T., and Anderson, T.H., 1974, Possible left-lateral early to middle Mesozoic disruption of the southwestern North American craton margin (abstract): Geological Society of America Abstracs with Programs, v.6, p.955-956.

Silver, L.T., Bickford, M.E., and Van Schinns, W.R., 1977, The 1.4-1.5 b.y. transcontinental anorogenic plutonic perforation of North America (abstract): Geological Society of America Abstracts with Programs, $v$. 9, $0.1176-1177$.

Stensrud, H.L., and More, S., 1980, Precambrian geology and massive sulfide environments of west-central Hualapai Mountains, Mohave County, Arizona - a preliminary report: Arizona Geological Society Digest, v. 12, p. $155-165$.

Stipp, T.F., Haigler, L.B., Alto, B.R., and Sutherland, H.L., 1967, Reported occurrences of selected minerals in Arizona: U.S. Geological Survey Mineral Investigations Map MR-46, scale 1:500,000, 2 sheets.

Suneson, N., and Lucchitta, L., 1979, K/Ar ages of Cenozoic volcanic rocks, west-central Arizona: Isochron/West, no. 4, p. 25-29.

Teichert, C., 1965, Devonian rocks and paleogeography of central Arizona: U.S. Geological Survey Professional Paper 464, 181 p.

Titley, S.R., 1982, Geologic setting of the porphyry copper deposits, in Titley, S.R., ed., Advances in geology of porphyry copper deposits: University of Arizona Press, Tuscon, p. 37-58. 

Titley, S.R., 1981, Geologic and geotectonic setting of porphyry copper deposits in the southern Cordillera, in Dickinson, W.R., and Payne, W.D., eds., Relations of tectonics to ore deposits in the southern Cordillera: Arizona Geological Society Digest, v. 14, p. 79-97.

Titley, S.R., 1976, Evidence for a Mesozoic linear tectonic pattern in southeastern Arizona: Arizona Geological Society Digest 10, p. 71-101.

Tucker, W.C. Jr., 1980, Tectonic geomorphology of the Luke Air Force range, Arizona: Arizona Geological Society Digest v. 12, p. 63-88.

U.S. Geological Survey, 1972 (some entries revised 1979), CRIB mineral resources file 12 (see individual mineral deposit descriptions for record and page numbers).

Warner, L.A., 1978, The Colorado lineament: A middle Precambrian wrench fault system: Geological Society of America Bulletin, v. 89, p. 161-171.

Wilson, E.D., 1962, A resume of the geology of Arizona: Arizona Bureau of Mines Bulletin $171,140 \mathrm{p}$.

Wilson, E.D., 1941, Tungsten deposits of Arizona: Arizona Bureau of Mines Bulletin $148,54 \mathrm{p}$.

Wilson, E.D., Moore, R.T., and Cooper, J.R., 1969, Geologic map of Arizona: Arizona Bureau of Mines and U.S. Geological Survey, scale 1:500,000.

Witcher, J.C., Stone, C., and Mahman, W.R., 1982, Geothermal resources of Arizona map: Arizona Bureau of Mines and Mineral Technology, scale $1: 500,000$. 
